\title{
Survey of Degradation Modes of Candidate Materials for High-Level Radioactive-Waste Disposal Containers
}

Volume 3

Localized Corrosion and Stress Corrosion

Cracking of Austenitic Alloys

J. C. Farmer, R, A. Van Konynenburg, and R. D. McCright

Lawrence Livermore National Laboratory

Livermore, Calif.

D. B. Butlen

Science \& Engineering Associates, [nc.

pleasanton, Calif.

April 1988

\section{DISCLAIMER}

\begin{abstract}
This report was prepared as an account of work sponsared by an agency of the Uniled States Governmen. Neither the Unite' Stales Gnvernment nor any agency thereof, nor any of their employees, makes any warranty, express or implied, or assumes any legal liability or responsibility for the accuracy. completeness, or uselulness of any information, appasatus, product, or process disclosed, or represents that its use would not infringe privately owned tights. Reference herein to any specific commercial product, process, or service by trade name, trademark, manufacturer, or otherwise does not necessarily constilute or imply its endorsement, recommendation, or favoring by the United States Government or any agency thereof. The views and opinions of authors expressod herein do not necessarily state or reflect those of the United States Government of any agency thereof.
\end{abstract}

\section{LAWRENCE LIVERMORE NATIONAL LABORATORY University of California - Livermore, California $\cdot 94550$}




\section{Contents}

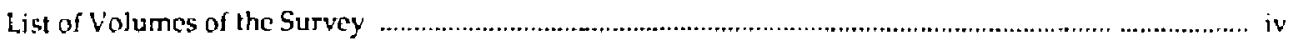

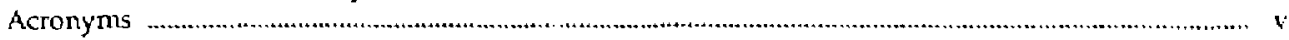

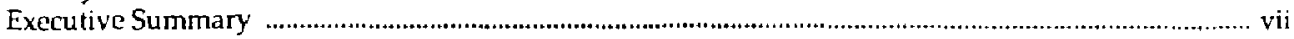

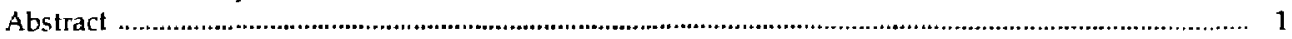

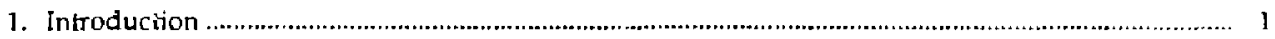

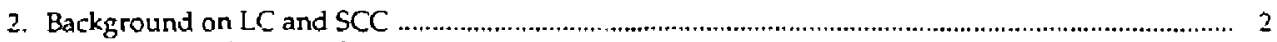

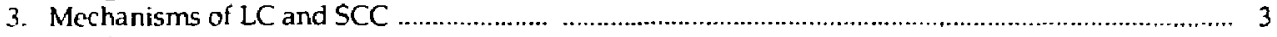

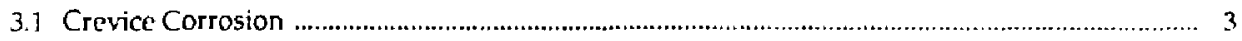

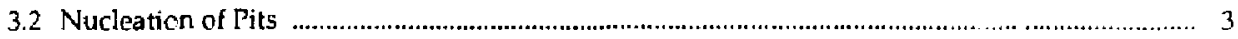

3.3. Crack Initiation at Pits Having Critical Depth ..................................................................... 11

3.4 Critical Potential for SCC Initiation in Sensitized Steels ................................................... 13

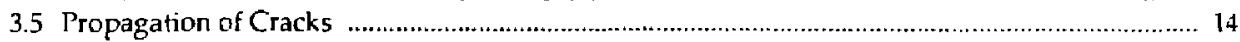

4. Data from the Literature on Pitting and SCC ............................................................................. 17

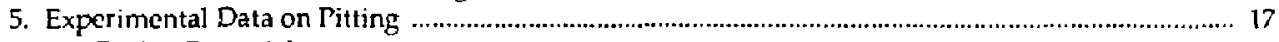

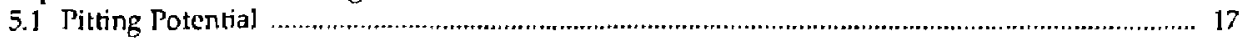

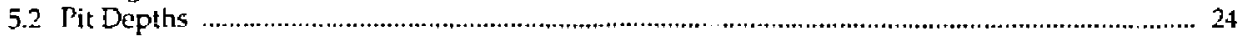

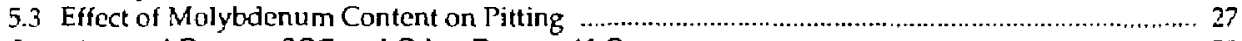

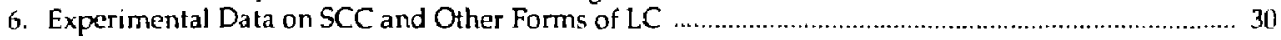

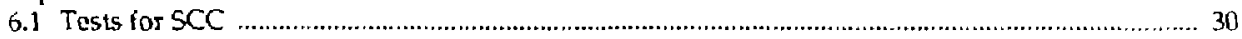

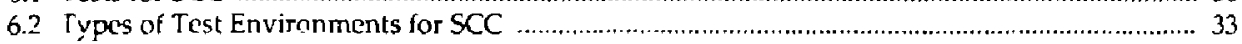

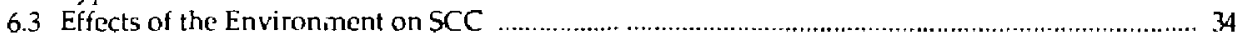

6.4 Effects of Alloy Composition on SCC .......................................................................... 40

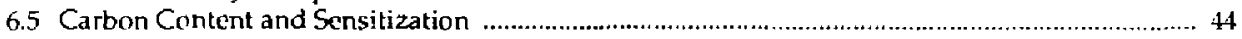

6.6 Eifect of Grain-Boundary Segregation on SCC .................................................................... 49

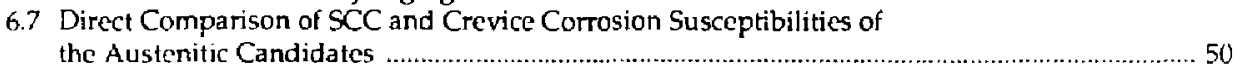

7. Lnusual Environmental Effects in the Repository: Gamma Irradiation and

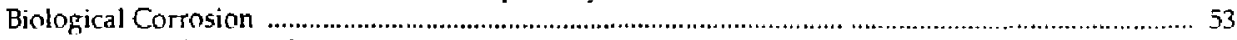

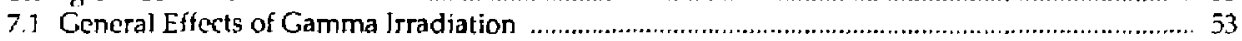

7.2 Effects of Ciamma Irradiation on SCC of Stainless Steels ....................................................... $\$ 4$

7.3 Effects of Biological Growtn on Pitting and LC ................................................................. 57

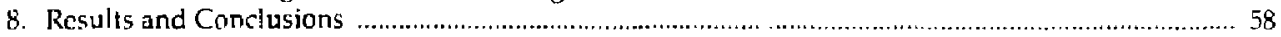

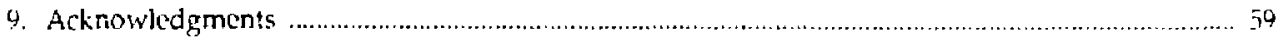

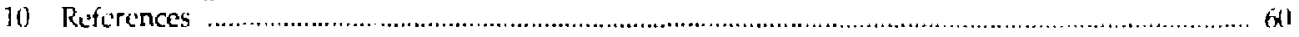




\section{List of Volumes of the Survey}

This is Volume 3 of the report Survey of Degratatim Modes of Candidate Matcrinls fur High-Level Radianctize-Waste Disposal Containers. The titles of a!l of the volumes ate a ; inllows:

Overview

Volume 1: Phase Stability

Volume 2: Oxidation and Corrosion

Volume 3: Localized Corrosion and Stress Corrnsion Cracking of Austenitic Alloys

Volume 4: Stress Corrosion Cracking of Copper-Based Alloys

Volume 5: Localized Corrosion of Copper Based Alloys

Volume 6: Effects of Hydrogen in Aust:nitic and Copper-Based Alloys

Volume 7: Weldability of Austeritic Alloys

Volume 8: Weldability of Copper-Based Alloys 


\section{Acronyms}

$\begin{array}{ll}\text { AES } & \text { Auger electron spectroscopy } \\ \text { AISI } & \text { American lron and Stecl lnstitute } \\ \text { ASTM } & \text { American Socicty for Testing and Materials } \\ \text { BWR } & \text { boiling-water reactor } \\ \text { CDA } & \text { Copper Development Association } \\ \text { CEMS } & \text { conversion-electron Mossbauer spectroscopy } \\ \text { CERT } & \text { constant extension rate testing, or test } \\ \text { CF } & \text { corrosion fatigue } \\ \text { CI } & \text { CERT index } \\ \text { COD } & \text { crack opening displacement } \\ \text { CSR } & \text { constant strain rate } \\ \text { DO } & \text { dissolved oxygen } \\ \text { DOS } & \text { degree of sensitization } \\ \text { ECP } & \text { electrochemical potential } \\ \text { EOAE } & \text { clectrolytic oxalic acid etch } \\ \text { EPR } & \text { electrochemical potentiokinetic reactivation } \\ \text { FS } & \text { furnace sensitization } \\ \text { HAZ } & \text { heat-affected zone } \\ \text { HVEM } & \text { high-voltage electron microscopy } \\ \text { ICSCC } & \text { intergranular stress corrosion cri. king } \\ \text { LC } & \text { localized corrosinn } \\ \text { MIC } & \text { microbiologically induced corrosion } \\ \text { KNWSI } & \text { Nevad. Nuclear Waste Storage Investigations Project } \\ \text { OFHC } & \text { oxygen-frec, high-conductivity } \\ \text { SA } & \text { solution annealing } \\ \text { SCC } & \text { stress corrosion cracking } \\ \text { SCE } & \text { saturated calomel electrode } \\ \text { SDR } & \text { slip dissolution-repassivation } \\ \text { SHE } & \text { standard hydrogen electrode } \\ \text { SP } & \text { shot peening } \\ \text { SSRT } & \text { slow strain rate testing, ar test } \\ \text { TGC } & \text { transgranular cracking } \\ \text { TGSCC } & \text { transgranular stress corrosion cracking } \\ \text { UTS } & \text { ultimate tensile strength } \\ \text { XPS } & \text { x-ray photoelectron spectroscopy } \\ \text { YS } & \text { yicld stress } \\ & \end{array}$




\section{Executive Summary}

This volume compares the corrosion properties of three austenitic alloys. These materials are leauing candidates for fabrication of the metal containers to be used in disposing of high-lewel radinactive waste at the prospective repository in Yucca Mountsin, Nevada. The three austenitic allnys, Types 3041 and 316L stainless steels and Alloy 825, are known for their good corrosion properties, their wide use in the marine, nuclear, and process industries, and ineir reasnnable costs. The corrosion properties of copper alloys that are being considered are discussed in Vols. 4 and 5.

Disposal containers can undergo several forms of degradation during their lifetimes, including localized corrosion (LC) and stress comosion cracking (SCC). SCC is a term used to describe service failures in cnginecring materials that occur by slow, environmentally induced crack propagation.

The selection of the candidate naterial that is adequate for repository conditions will be based on three tasks: a literature survey, corrosion te'jling, and predictions from: models. Lawrence Livermore National Laboratory has responsibility for all three. This report is a survey of the literature on LC and on SCC.

Section 1 of this report is an introduction, and Sec 2 provides a background on LC and SCC. Section 3 describes (1) the two forms of LC, which are crevice corrosion and pitting, (2) the role of pilting in initiating cracks, and (3) the propagation of cracks during SCC. Crevice corrosion occurs within crevices and other shielded areas on metal surfaces and consisls of anodic dissolution of metal and undesirable halide, edctions, in an accelerating process. The suppression of pht and the depletion of cowgen in crevices could enhance other forms of attack, such as pitting and SCC. The initiation of pitting depends on various conditions, such as chloride concentration, $\mathrm{pH}$, and temperature. Models of initiation of pitting conable us to predict the effect of these conditions on critical pitting potential and on induction tince, twe guantities used to describe a $r$ :!'s resiat: nce to pitting and to measure the effects of

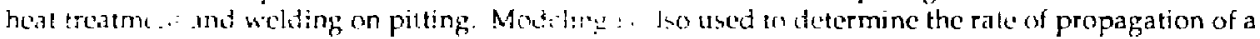
frowing pit.

Section 3 continues with a diteussion of several nodels that describe the initiation of SCC by pitting. SCC can also be initiated by inter 5 ranular corrosion and slip dissolution. SCC begins at the critical potential, a quantity used to measure susceptibility to stress corrosion and to predict environmental conditions that lead to SCC. A discussion of the mechanisms of crack propagation concludes the section.

Section 4 introduces our review of the literature. Section 5 reviews the literature on pitting for the three austenitic candidates and for other alloys. Data are included on pitting potential, pit depth, and the cffect of molybdenum.

Section 6 reviews the experimental data on SCC, and, to a iesser extent, the data on pitting and crevice corrosion. It begins by describing the three tests for SCC: (1) tests on statically loaded smooth samples, (2) tests on statically loaded precracked samples, and (3) lests using slowly strained samples. Much of the data for SCC in the literature comes from classic U-bend and beam experit ints (statically loaded samples), and. recently, from slow strain rate testing (SSRT). A discussion then follows on the type of environments used to test for SCC and how envirnnmental parameters influence the rate of crack gromith. The effects of alloy composition, namely, nickel content, on SCC are discussed, and the role of carbon content in sensitization is cxamined. (Sensitization is increased susceptibility to attack following a thermal exposure that causes chromium carbide precipitation with consequent localized chromium depletion.) Various tests measuring the degree of sensilization are uned to describe stress-corrosion susceptibility and crack growth rate. The role of grain-boundary segregation of impurities in austenitic alloys is also examined. The section concludes with a direct comparison of the SCC susceptibilities of the austenitic candidates.

Section 7 discusses two unusual environmental factors in the repositnry: high fluxes of gammat radiation, and microbiologically induced corrosion. Ganma radiation produces several reactive species in witcr as woll as permanent thanges in the oxide fayer on the sted. Microbiolsgically induced corrosion cannot be totaliy ruled out, hut the dry, radicative enviennment of the containers would mate it appear very unlik.ly. 
The conclusions of the report are given in Sec. 8 and can be summarized as follows:

1. All austenitic candidates (Types 304L and 316L stainless steels and Alioy 825) demonstrate pitting and crevice cotrosion in chloride-containing environments.

2. Alloy 825 has greater resistance to pitting and crevice corrosion than cither Typos $304 \mathrm{~L}$ or $316 \mathrm{~L}$ stainless stecls.

3. SCC was not reported in the literature for Alloy 825. This does not mean that SCC could not occur in Alloy 825 under other circumstances.

4. On the basis of the data from the literature on susceptibility to SCC, the candidates are ranked as follows: Alloy 825 (best) $>$ Type $316 \mathrm{~L}>$ Type $304 \mathrm{~L}$ (worst). Note that much of the data in this report is for solutions having higher ionic strengths than expected in the groundwater near the repository. However, these data are believed to be relevant since refluxing can concentrate water falling onto container surfaces.

5. Gamma irradiation enhances SCC of Types 304 and 316L stainless steels under some conditions. Alloy 825 , however, shows no change in its resistance to SCC in the presence of gamma irradiation.

6. Though microbiologically induced (or influenced) corrosion and possible SCC have been observed for 300-scries stainless steels, the nickel-based alloys such as Alloy $825 \mathrm{scem}$ to be immune tu such problems. 


\title{
Survey of Degradation Modes of Candidate Materials for High-Level Radioactive-Waste Disposal Containers
}

\author{
Volume 3: Localized Corrosion and Stress Corrosion \\ Cracking of Austenitic Alloys
}

\begin{abstract}
Three iron- to nickel-based austenitic alloys (Types 304L and 316 stainless steels and Alloy 825) are being considered as candidate materials for the fabrication of highlevel radioactive-waste containers. Waste will include fuel assemblies from reactors as well as high-level waste in borosilicate glass forms, and will be sent to the prospective repository at Yurca Mountain, Nevada.

The decay of radionuclides in the repository will result in the generation of substantial heat and in fluences of gamma radiation. Container materials may undergo any of several modes of degradation in this environment, including atmospheric oxidation; uniform aqueous phase corrosion; pitting; crevice corrosion; sensitization and intergranular stress corrosion cracking (IGSCC); ind transgranular stress corrosion cracking (TGSCC). This report is an analysis of data selevant to the pitting, crevice corrosion, and stress corrosion cracking (SCC) of the three austenitic candidate alloys. The candidates are compared in terms of their susceptibilities to these forms of corrosion.

Although all three candidates have demonstrated pitting and crevice corrosion in chloride-containing envirorments, Alloy 825 has the greatest resistance to these types of localized corrosion (LC); such resistance is important because pits can penetrate the metal and serve as crack initiation sites. Both Types $304 \mathrm{~L}$ and $316 \mathrm{~L}$ stainless steels are susceptible to SCC in acidic chloride media. In contrast, SCC has not been documented in Alloy 825 under comparable conditions. Gamma radiation has been found to enhance SCC in Types 304 and 304L stainless steels, but it has no detectable effect on the resistance of Alloy 825 to SCC. Furthermore, while the effects of microbiologically induced corrosion have been observed for 300-series stainless steels, nickel-based alloys such as Alloy 825 seem to be immune to such problems.

This analysis indicates that the candidates should be ranked according to their resistance to LC and SCC as follows: Alloy 825 (best) > Type 316L > Type 304L (worst).
\end{abstract}

\section{Introduction}

Austenitic alloys and copper-based alloys are being considered as candidate materials for fabrication of the metal containers to be used in disposing of high-level radioactive waste at the Yucca Mountain site in Nevada. The austenitic materials are Types $304 \mathrm{~L}$ and $316 \mathrm{~L}$ stainless steels and Alloy 825 (Incoloy). These materials are leading candidates because of their good corrosion properties, their wide use in the marine, nuclear, and process industries, and their reasonable costs. There are also three cupper-based candidate alloys, which are discussed in Vol. 2 of this report; these are CDA 102 (OFHC Cu), CDA 613 (Cu$7 \mathrm{Al})$, and $\mathrm{CDA} 715$ (Cu-30Ni).

The containers must maintain mechanical integrity for $50 \mathrm{yr}$ and substantially complete 
containment for 300 to $1000 \mathrm{yr}[1,2]$. Radioactive decay of the stored waste results in substantial heat generation. Initially, many of the containers will rise to a peak temperature of about $250^{\circ} \mathrm{C}$. After $100 \mathrm{yr}$, the temperature will drop to about $150^{\circ} \mathrm{C}$ and will continue dropping slowly. Containcrs with lower heat output and those focated at the edge of the repository will have lower temperatures.

After emplacement, the container materiais could undergo any of several modes of degradation, including atmospheric oxidation, general aqueous phase corrosion, and various forms of tocalized corrosion (LC). LC phenomena include crevice corrosion, pitting, intergranular stress corrosion cracking (JGSCC), and transgranular stress corrosion cracking (TGSCC).

After heat treatment at temperatures above $500^{\circ} \mathrm{C}$, austenitic stainless steels may become unu sually suscepible (semsitized) to IGSCC because of the precipitation of $\mathrm{Cr}_{23} \mathrm{C}_{6}$ particles at grain boundaries. The chromium-depleted region adjacent to the grain boundary serves as a vulnerable pathway for corrosive attack. Sensitization could be a serious problem in the heat-affected zone (HAZ) near welds. Corrosion phenomena can also be perturbed by the radiation field that exists in close proximity to the container. Radiolysis of salt-containing condensate films and air generates ionic, free radical, and molecular species that are not present under normal nonisradiated circumstances.

The Metal Barrier Selection and Testing Task of the Nevada Nuclear Waste Storage investigations (NNWSI) Project has to select the candidate material with adequate performance under repository conditions. This selection will be based on a survey of the literature, corrosion testing at Lawrence Livermore Natinnal Laboratory and subcontractors, and predictions from models. The relevant literature on LC and stress corrusion cracking ( $5 \mathrm{CC}$ ) in the three austenitic alloys is reviewed in this volume, and the candidates are ranked in order of their susceptibility to these modes of degradation. Over 1000 articles were reviewed for this volume, and of those, the most relevant $\mid 1-211]$ were selected for discussion. A detailed discussion on the methodology and extent of the literature search and on the selection of references can be found in the Overview."

\section{Background on LC and SCC}

SCC is a term used to describe service failures in engineering materials that occur by environmentally induced crack propagation. The observed crack propagation is the result of the combined and synergistic interaction of mechanical stress and corrosion reactions.

Penctration rates at local sites of corrosive attack (LC) are far more serious threats to container life than rates due to unifors a tmospheric and aqueous phasc corrosion. Ionic arid molecular species present in aqueous environments (water and moisture films) can serve as pronoters, depolarizers, or inhibitors of LC and SCC in austenitic materials $[3,4]$. For exampie, $\mathrm{F}^{-}, \mathrm{Cl}^{-}$, $\mathrm{Br}$, and $\mathrm{S}_{2} \mathrm{O}_{3}^{2-}$ can induce localized breakdown of passive films, thereby initiating pit formation; sucl species are known as promoters. Unpublished results exist which: indicate that $\mathrm{SO}_{4}^{2-}$ may also serve as a promoter.

Frequently, stress corrosion cracks initiate at pits. Anodic dissolution at the bases of pits and at crack tips can be enhanced by a number of depolarizers, including $\mathrm{O}_{2}, \mathrm{H}^{+}, \mathrm{Fe}^{3+}, \mathrm{Cu}^{2+}$, and $\mathrm{Hg}^{2+}$.
The cathodic reduction of depolarizers on surfaces outside of crevices, pits, and cracks can galvanically couple with anodic dissolution and oxidation processes that occur inside pits. In contrast to $\mathrm{Cl}^{-}$, ions such as $\mathrm{NO}_{3}, \mathrm{I}^{-}$, and acetatc are known inhibitors of pitting and SCC of austenitic stainjess stecls. These inhibitors compete with halide ions for adsorption sites on the metal oxide film and base metal. In alkaline media, $\mathrm{OH}^{-}, \mathrm{H}^{*}$, and $\mathrm{PO}_{4}$ can serve as promoter, depolarizer, and buffer, respectively.

In addition to corrosive attack, mechanical stress is required for SCC. The stresses required are smail, usually below the macroscopic yield stress, and are tensile in nature. The stresses can be extemally applied, but residual stresses often

- J. C. Farmez, R. D. McCright, J. N. Kass, Survey of Degradation Modes of Candidate Materials for Iligh-Leze! Radioactive-Waste Disposa! Containers, Overview, Lawrence Livermore National Laboratory, Livermore, California, UCID-21362 Overview (198B). 
cause SCC failures. One frequent misconception is that SCC is the result of stress concentration at corrosion-generated surface flaws (as quantified by the stress intensity factor, $K$ ), and that when a critical value of stress concentration, $K_{\text {arit }}$, is reached, mechanical fracture results. Although stress concentration does occur at such flaws, it does not in fact exceed the critical value required to cause mechanical fracture of the material in an inert environment $\left(K_{\mathrm{SCC}}<K_{\text {crit }}\right)$.

\section{Mechanisms of LC and SCC}

\subsection{Crevice Corrosion}

Intense LC frequently occurs within erevices and other shielded arcas on metal surfaces exposed to corrosives. After placement of the comitainers in the repository. crevices will form at prints where the container is supported. Furthiemore, natural deposits of sand, dirt, corrosion products, and other solids can form crevices

During uniform aqueous phase corrosion, the cathodic reduction of dissolved oxygen and the anodic dissolution of metal cations are galvanically coupled and proceed at rates that are independent of pusition on exposed metal surfaces. In contrast, oxygen reduction on metal surfaces in crevices eventually ceases because of the lack of this reactant. Oxygen becomes depleted in such recesses, and mass transport rates (diffusionlimited) are insufficient to replenish it. Consequently, the only process that occurs at an appreciable rate within the crevice is the anodic dissolution of metal. This tends to produce an excess of posituve charge in the crevice solution $\left(M^{z+}\right)$, which is necessarily balanced by the migration of halide ions, such as $\mathrm{Cl}^{-}$, into the recess. The increased concentration of metal halide in the crevice results in undesirable, localized chemistry.

$\mathrm{MCl}+\mathrm{H}_{2} \mathrm{O} \rightarrow \mathrm{MOH}$ (prec.) $+\mathrm{HCl}$

The halide salt hydrolizes in water to form a precipitate and free acid. Repassivation in the high-chloride, low-pH environment found in crevices is virtually impossible. The anodic dissolution of most metals is accelerated in such environments.

In addition to the large differences in concentration that exist inside and outside of crevices, there are large differences in current density. Oxygen reduction continues at relatively low current densities on all passivated loxidecovered) metal surfaces outside of the crevice. This large overall cathodic current must be balanced by the anodic dissolution current on metal surfaces inside the crevice. Given the small active area within crevices, corresponding current densities are typically very large. Therefore, local penetratiun rates within crevices also tend to be very large (far greater than on unobscured surfaces).

\subsection{Nucleation of Pits}

It is important to understand the dependence of pitting on various environmental conditions such as chloride concentration, $\mathrm{pH}$, and temperature. Modeds of pitting phenomena fall into two broad classes: initiation and propagation. Pitinitiation models enable us lo predict the effects of environment on quaritites such as the critical pitting potmital and induction time $[5,6]$. Once a pit is initiated, it is necessary to calculate the rate of propagation (penetration). Models like the one presented by Pickering and Frankenthal enable us to calculate $\mathrm{pH}$ depression inside the growing pit. the concentration of other species inside the pit, and the rate of propagation [7]. The application of stochastic probability theory may make it possible to account for observed variances in critical pitting potential. Furthermore, the rate of pitting can be determined from logarithmic plots of survival probability as a function of time [8].

Okada assumes that pit inituation on a stainless sted begins with formation of a henispherical halide nucleus on the passive oxide film $[5,6]$. If the nucleus is stable and grows continuously, it will eventually breach the protective oxide. After dissolution of the metal halide, the underlying metal is exposed and undergoes rapid corrosive attack. This mechanism is illustrated in Fig. 1. The following reactions are assumed to occur at the interface between the halide nucleus and the passive oxide:

$\mathrm{M}^{z+}(\mathrm{oxide})+z \mathrm{X}$-(halide $) \rightarrow \mathrm{MX}_{2}$ (halide $)$
$\mathrm{O}^{2-}$ (oxide $)+2 \mathrm{H}^{-}$(halide $) \rightarrow \mathrm{H}_{2} \mathrm{O}$ (halide $)$ 

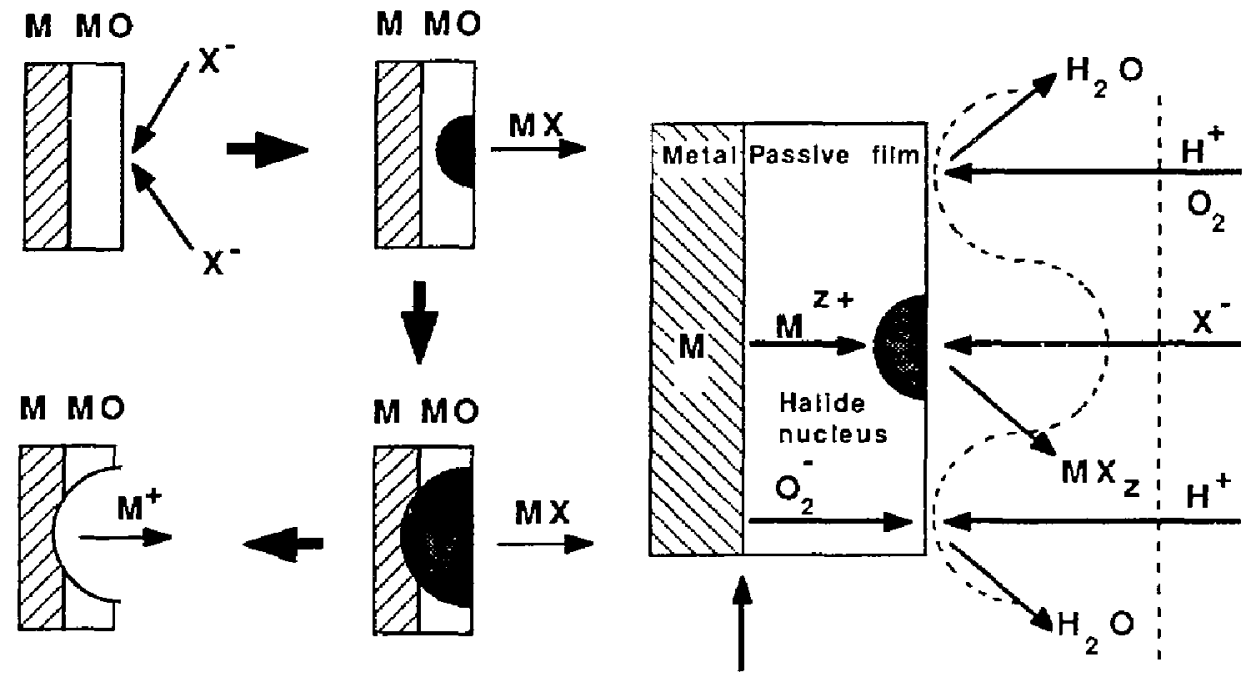

Equipotential lines

Figure 1. Stages of pit initiation on stainless steel as proposed by Okada $[5,6]$.

At the interface between the metal halide and the solution, these reactions are assumed:

$$
\begin{aligned}
& \mathrm{M}^{\mathrm{z}+} \text { (halide) } \rightarrow \mathrm{M}^{\mathrm{z}} \text { (solution } \\
& \mathrm{X}^{-} \text {(halide) } \rightarrow \mathrm{X}^{-} \text {(solution) }
\end{aligned}
$$

Okada has used two independent approaches to derive the same expressions for the critical pitting potential, $E_{C}$, the induction time, $\tau$, and the critical size for a stable halide nucleus, $r^{*}$. Note that the critical pitting potential is a lincar function of the logarithm of the halide ion concentration, $\ln \mid \mathrm{X}-\mathrm{|}$.

$E_{\mathrm{c}}=$ constant $-(R T / F) \ln \left[\mathrm{X}^{-}\right]$

where $R$ is the universal gas constant, $T$ is the absolute temperature, and $F$ is Faraday's constant. This relationship between the critical pitting potential and halide ion concentration is consistent with the experimental results of several different research groups [9-11]. For example, variations of the pitting potential for Type 316 stainl .ss sted in cellulose bleach solutions at $50^{\circ} \mathrm{C}$ have been correland with chloride concentration and $\mathrm{pH}$, as shown in Fig. 2 and Eq. (6a) |71]. Note that the pitting potential calculated by Eq. (6b) has the units of $\mathrm{mV}$, SCE.

$E_{\mathrm{C}}=2570-5.81 T+0.07 T \cdot \mathrm{pH}-0.49 T \log |\mathrm{Cl}-|(6 \mathrm{~b})$

The induction time is a function of both the halide jon concentration and the electrochemical potential, $t$.

$\ln \tau=$ constant $-2 n \ln \mid X-1-(2 F E / R T)$

where $n$ is the valence of the metal cation. Note that $\mathrm{Eq} .(7)$ implies that the indiuction time increases exponentially as the chloride concentration decreases.

As noted above, Okada has used two independent approaches to derive these expressions for the critical pitting potential and the induction time for pit initiation. The first approach begins with the general evolution criterion proposed by Glansdorff and Prigogine for irreversible thermodynamics |Okada, Ref. 5|. The second approach assumes that small, localized anodic perturbations in the electrochenical potential are sufficient to nucleate patches of metal halide on the 


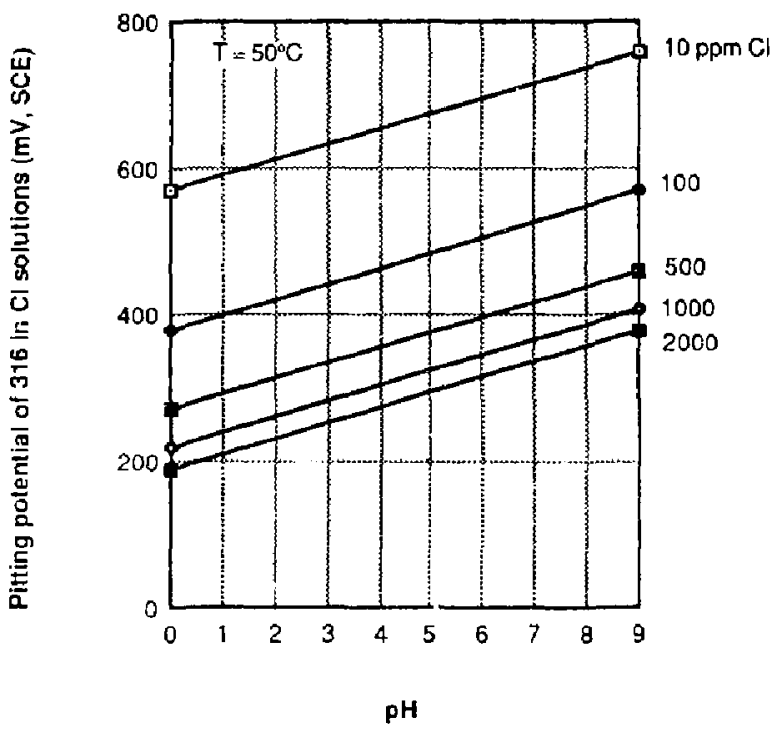

Figure 2. Variation of the pittin 5 potential of Type 316 stainless steel with chloride concentrati. 1, pH, and temperature, in cellulase bleach solutions at $5[0 ; 11]$.

oxide film |6|. At relatively anodic potentials, the halide is more stable than the oxide. Other models of pit initiation exist, such as the point defect model [12].

Pits can also nucleate at inclusions in the alloy surface. In 1980, Manning et al. published a study which determined the effect of sulfide inclusion morphology and composition, matrix, and cnvironmental variables such as $\mathrm{pH}$, temperature, and $\mathrm{X} \cdot \mathrm{Cl}$ concentration on pit-initiation resistance [13]. Pitting corrosion tests were performed on Types $304 \mathrm{~L}, 376$, and $316 \mathrm{~L}$ stainless steels. The sulfide-inclusion morphology was altered with high-temperature heat treatments.

Manning et al. conducted tests on as-received samples (10\% cold worked), samples heat-treated at 130$)^{\circ} \mathrm{C}$ for $8 \mathrm{hr}$ and water-quenched, and samples annealed at $1050^{\circ} \mathrm{C}$ for 5 to $7 \mathrm{~min}$ and waterquenched. The amealing treatment at $1050^{\circ} \mathrm{C}$ did not cluange the grain size or the sulfide-inclusion morriniogy of the as-received material. However, the high-temperature heat treatment $\left.(130)^{\circ} \mathrm{C}\right)$ resulted in substantial grain growth and spheroidization of sulfide stringers. In the asreceived condition, the length of sulfide inclu- sion/metal interface per unit area of microstructure $\left(L_{A-M e / s}\right)$ was $26 \mathrm{~mm} / \mathrm{mm}^{2}$, which was almost identical to the valuc obtained for annealed material. In contrast, the value of $\mathrm{L}_{\mathrm{A}-\mathrm{Mc} / \mathrm{S}}$ decreased to $15 \mathrm{~mm} / \mathrm{mm}^{2}$ after hightemperature heat treatment. Potentiodynamic pitting tests of heat-treated samples ivere performed at a potential sweep rate of $100 \mathrm{mV} / \mathrm{hr}$ in $1 \mathrm{~N} \mathrm{NaCl}\left(\mathrm{pH} 4,32^{\circ} \mathrm{C}\right)$.

In comparing pitting resistance to that of other heat treatments of Type $304 \mathrm{~L}$ or other 300 series stainless stecls in which pit initiation occurs at metal/sulfide interfaces, the value of $L_{A-M e / s}$ is not the critical factor. The matrix composition as well as the composition of the sulfide inclusions are the primary factors determining the elative resistance to pit initiation of these alloys.

Figure 3 illustrates the importance of sulfideinclusion morphology on pitting potential, a measure of a material's tendency to pit. As-received and annealed Type $316 \mathrm{~L}$ stainless steels have pitting potentials much more cathodic than those of Type 304L, even though the molybdenum content of Type $316 \mathrm{~L}$ is higher than that of Type $304 \mathrm{~L}$. As will be discussed, molybdenum additions usually 


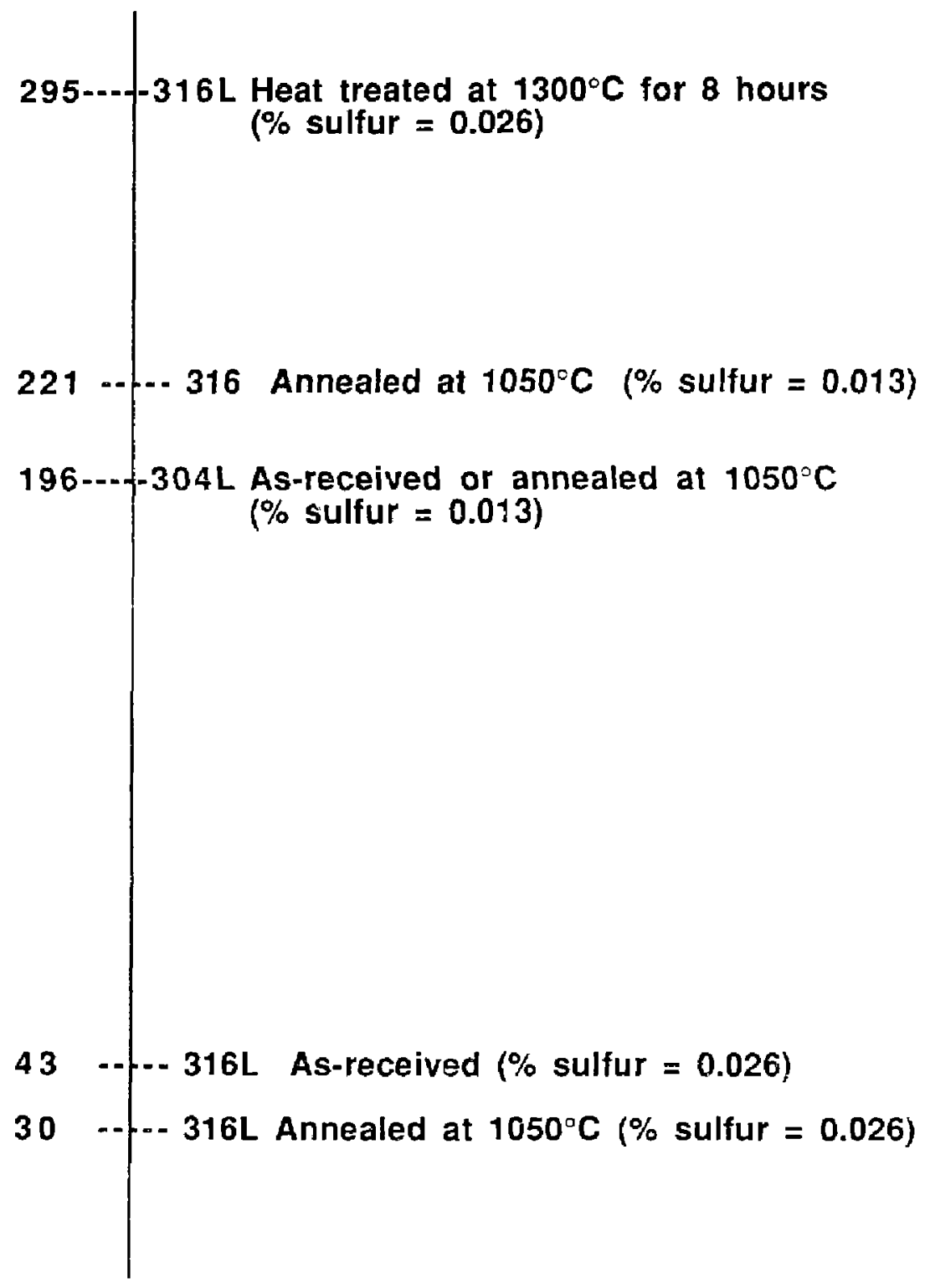

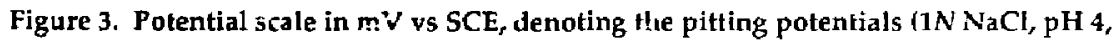
$22^{\circ} \mathrm{C}$ ) of several single-phase alloys with different heat treatments. [13]. 
enhance resistance to pitting. However, in ihis case, the pitting resistance of the alloy having high molybdenum content is actually lower because of the presence of sulfide inclusions that have a higher content of sulfur. Note that as-received and heat-treated Type 316L specimens have twice as much sulfur as the Type $304 \mathrm{~L}$ sprecimens. Type 316 stainless steel annealed at $10511^{\circ} \mathrm{C}$ and having the same sulfur content as Type $304 L$ exhibits more resislance to pitting (higher pitting potential) because of its greater molybdenum content. Pitting resistances of highsulfur $(0.026 \%)$ Type $316 \mathrm{~L}$ can be restored by heat treatment at $1300^{\circ} \mathrm{C}$, which alters sulfideinclusion morphology. Note that the annealed
Type 316 and as-reccived and annealed Type $304 \mathrm{~L}$ had essentially the same $L_{A-M e} / S$ values ( $L_{A-M e / S}=26.6 \mathrm{~mm} / \mathrm{mm}^{2}$ for $304 \mathrm{~L}$ ).

Manning et al. also performed tests on asreceived single-phase and as-welded duplex Type $304 \mathrm{~L}$ stainless steel as a function of environmental variables. The temperatures studied were 8,22 , 50, and $90^{\circ} \mathrm{C}$. The $\mathrm{NaCl}$ concentrations used were $0.1,0.5$, and $1 \mathrm{~N}$. By adding $\mathrm{HCl}$ or $\mathrm{NaOH}$, the $\mathrm{pH}$ was controlled at a value in the range of $\mathrm{pH} 2$ to 12. The data in Figs. 4 and 5 show that a linear relationship exists between the pilling potential and the logarithm of the $\mathrm{NaCl}$ concentration. This resuit applies to single-phase and duplex alloys in solutions at $\mathrm{pH} 2$ and 4 within a temperature

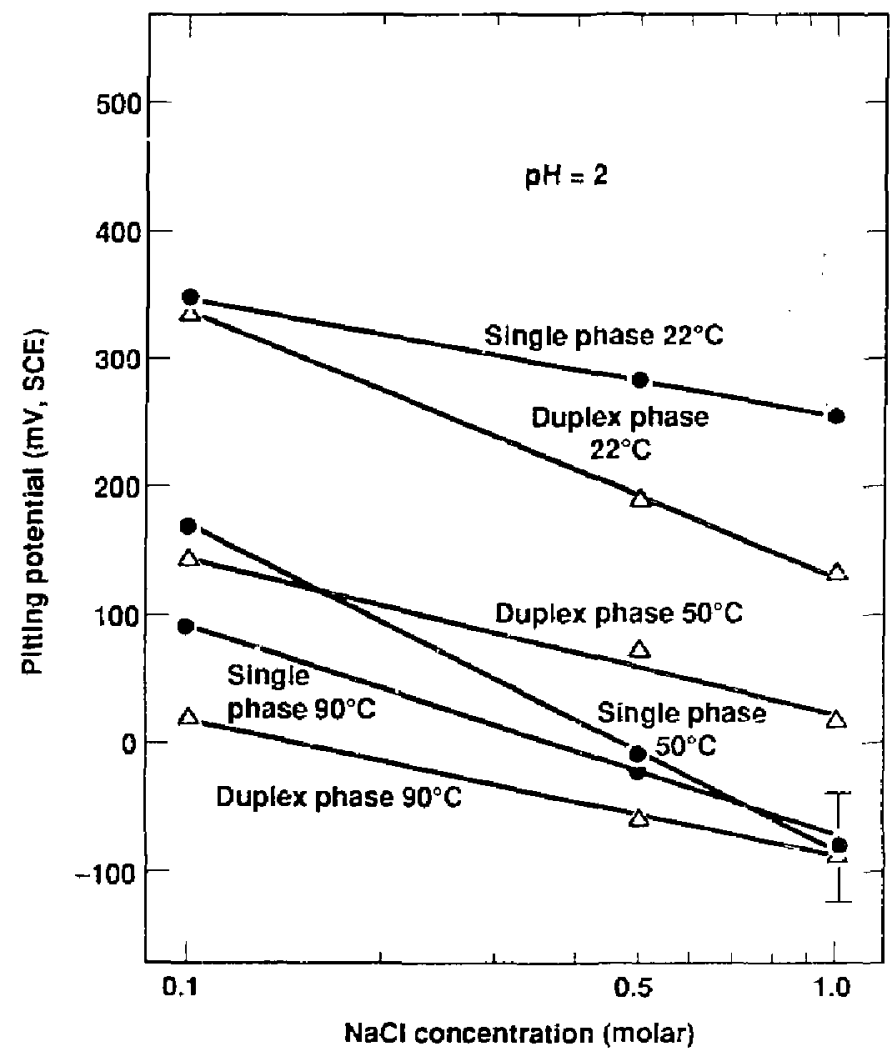

rigure 4. The pitting potential of Type 304L. stainless steel has a linear relationship with the logarithm of the $\mathrm{NaCl}$ concentration at $\mathrm{pH}=2$ [13]. 


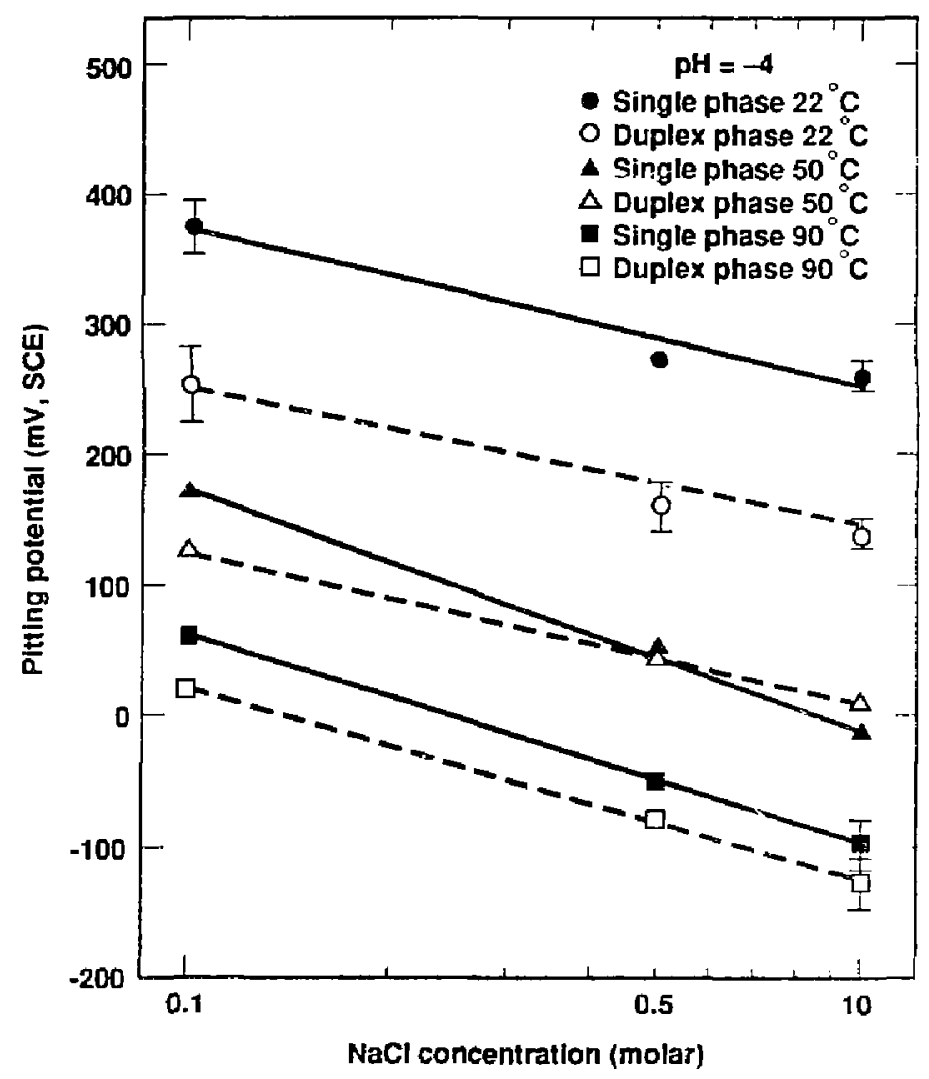

Figure 5. Pitting potential of Type 304L stainless steel at $p H=4$. As in Fig. 4, the relationship is linear.

range of 22 to $90^{\circ} \mathrm{C}$ and is consistent with the expressions derived by Okada and the correlation given by Matamala [11].

The data in Fig, 6 show the effect of PH on pitting potential in $1 \mathrm{~N} \mathrm{NaCl}$ at various temperatures. For a $\mathrm{pH}$ value less than some critical value, the pitting potential is relatively independent of $\mathrm{pH}$. For alkaline solutions, pitting resistance is improved at a $\mathrm{pH}$ value greater than 7 at $22^{\circ} \mathrm{C}, 9$ at $50^{\circ} \mathrm{C}$, and 10 at $90^{\circ} \mathrm{C}$. At $22^{\circ} \mathrm{C}$, the pitting resistance of the duplex alloy is inferior to that of the single-phase alloy below the transition$\mathrm{pH}$ value. However, at higher temperatures, the iwo types of alloys behave in a similar manner. It may be noted that at $50^{\circ} \mathrm{C}$, the single-phase alloy shows a statistically significant decrease in pitting resistance at $\mathrm{pH} 2$. It has been suggested that the discontinuous change in pitting resistance at a high $\mathrm{pH}$ value may be attributed to preferential adsorption of $\mathrm{OH}^{-}$jons competing with $\mathrm{Cl}^{-}$ions. If this hypothesis is correct, the increase in transition $\mathrm{pH}$ with increasing femperature could be explained by less stable adsorption at high temperatures.

The effects of temperature on pitting potential in electrolytes with various concentrations of $\mathrm{NaCl}$ are shown in Fig. 7 (pH 4) and in Fig. 8 (pH 2). As the temperature is increased from 8 to $90^{\circ} \mathrm{C}$, there is a continuous shift of pitting potential in the active direction at $\mathrm{pH}$ 4. At $\mathrm{pH} 2$, however, a discontinuous decrease in pitting resistance of the single-phase alloy is observed in 0.5 and $1 \mathrm{~N} \mathrm{NaCl}$ at $50^{\circ} \mathrm{C}$, and the pitting potential is approximately constant at $90^{\circ} \mathrm{C}$. This behavior is 


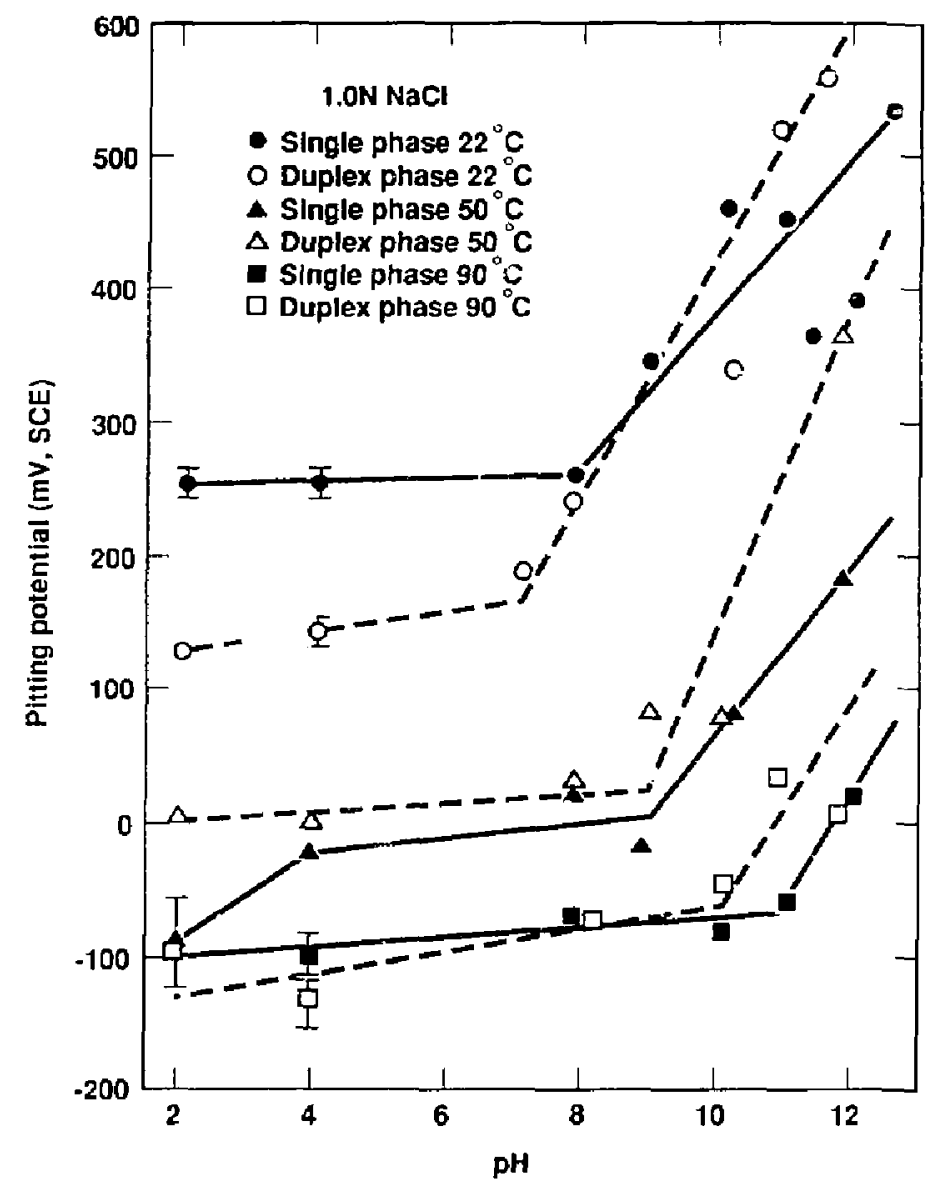

Figure 6. Pitting polentials of single-phase and duplex Type 304L as a function of $\mathrm{pH}$ at several temperatures in $1 \mathrm{~N} \mathrm{NaCi}$ [13].

associated with the dissolution kinetics of the sulfjde inclusions (most susceptible site for pit initiation) as a function of environment. The duplex-alloy data in Figs. 3 through 7 show that acidification of the electrolyte from $\mathrm{pH} 4$ to 2 does not significantly affect the pitting potential in the case where sulfide-dissolution kinetics do not play a role in the pil-initiation process.

In summary, Manning et al. drew the following conclusions:

(1) A rank order of resistance to pit initiation of the base materials examined is dependent upon sulfur content as w'ill as molybdenum content. Type $316 \mathrm{~L}$ stainless sted that had $0.026 \%$ sulfur and was heat-treated at $1.300^{\circ} \mathrm{C}$ for $8 \mathrm{hr}$ was most resistant to pitting, while the sume material in the as-received and annealed condition was less resistant to pitting than as-reccived and annealed Type $304 \mathrm{~L}$ having only $0.013 \%$ sulfur. Annealed Type 316 that had the same sulfur content as Type 304L was more resistant to pitting than Type 304L, primarily because of the relative differences in molybdenum content. All annealing was done at $1050^{\circ} \mathrm{C}$.

(2) Sulfide-dissolution kinetics are presumed to control pit initiation of singlr-phase Type 304L stainless sted. The kinclics were influenced by the following variables: the me thod of 


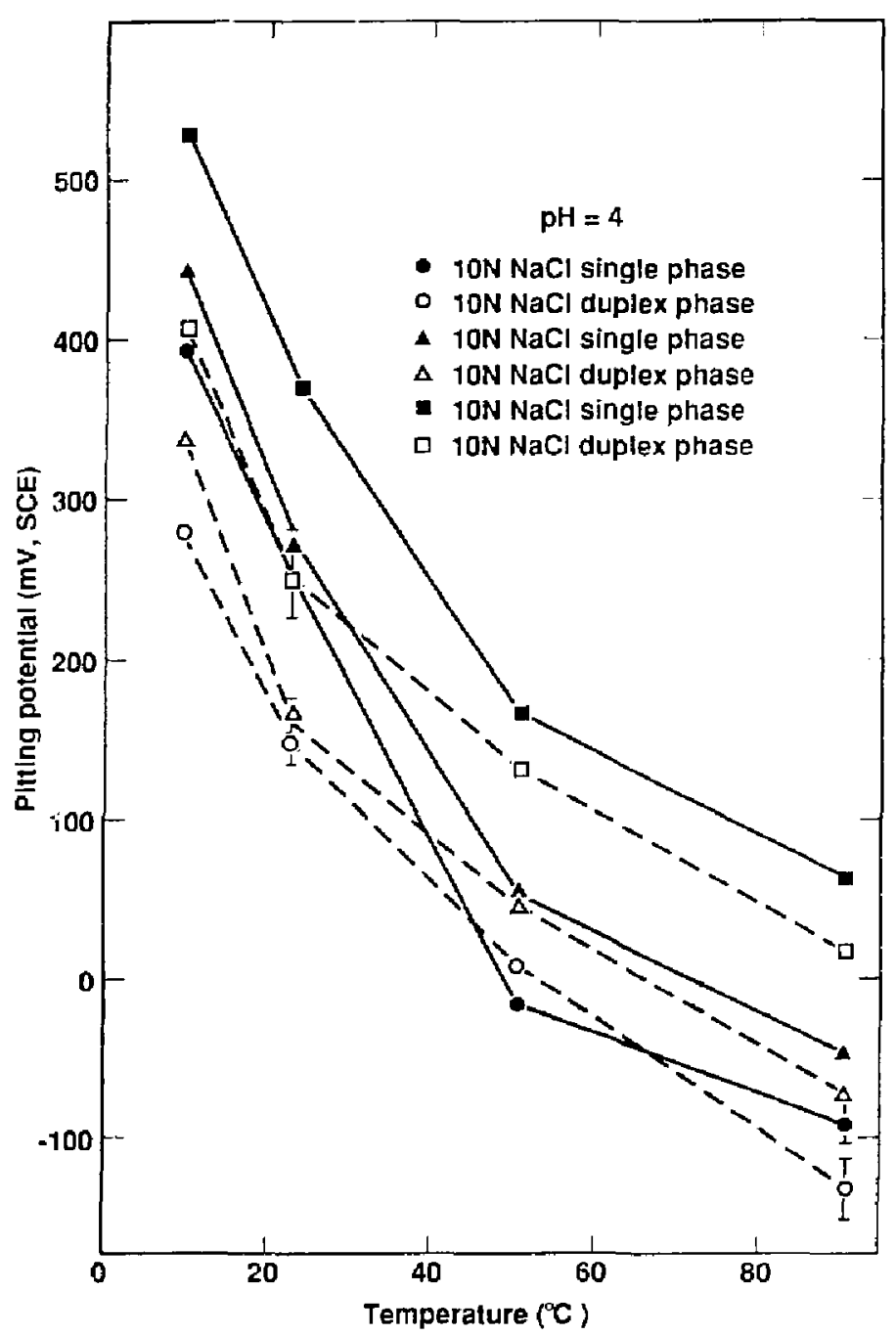

Figure 7. Pitting potentials of single-phase and duplex Type 304 as a function of temperature in several $\mathrm{NaCl}$ concentrations with a constant $\mathrm{pH}$ of $4[13]$.

conducting the pit-initiation test, the morphology of the sulfide ine witons exposed to the electrolyle, and the composition and temperature of the bulk electrolyte. Sulfide-inclusion morpholegy was controlled by heat treatment.

(3) Dissolution hegins at sulfide/metal interfaces when chloride ions are present and a poten- tial is applied at which suliide inclusions of a particularly susceptible composition are thermodynamically unstable. Acidification of the local electrolyte as woll as concentration of chloride ions occur by migration. If geometrical conditions favor pit propagation, dissolution of the metal around the sulfide inclusion continues; if 


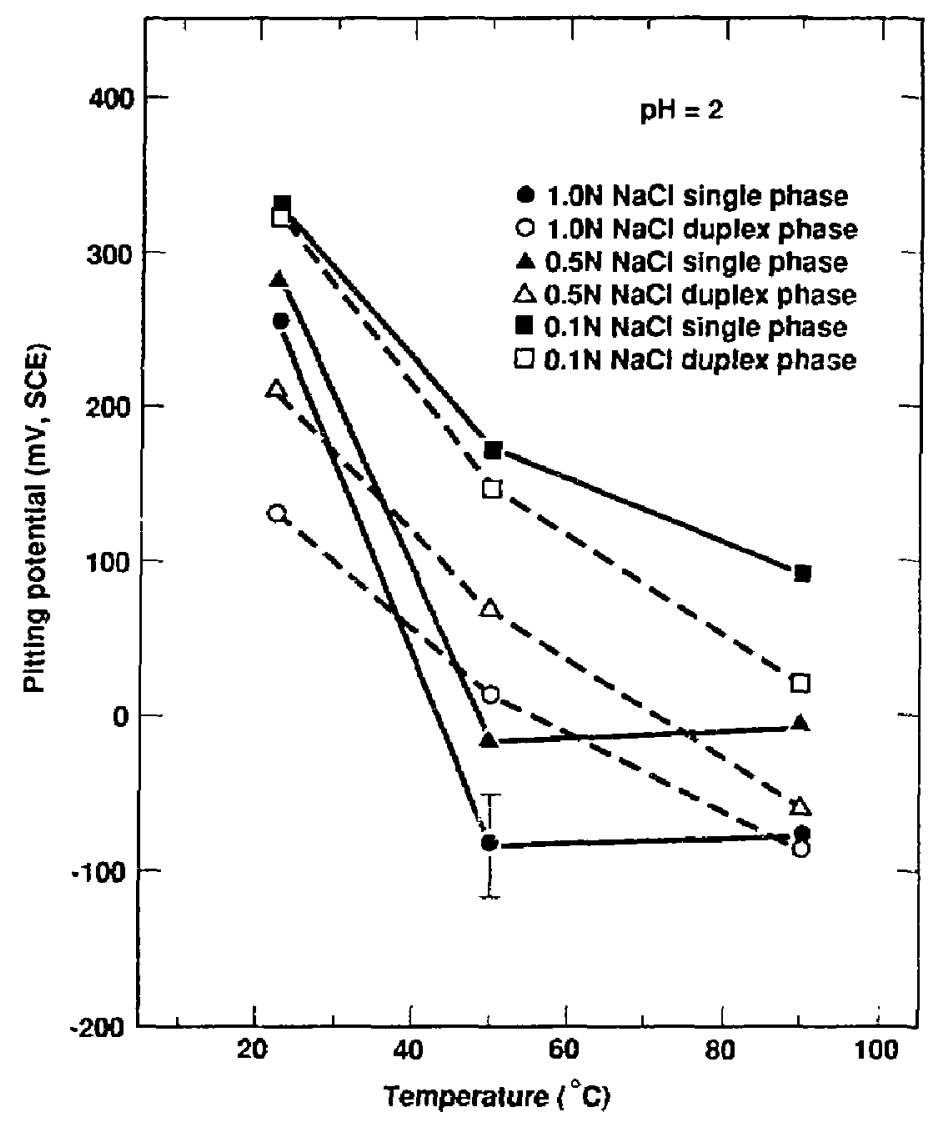

Figure 8. Pitting potentials of single-phase and duplex Type $304 \mathrm{~L}$ as a function of temperature in several $\mathrm{NaCl}$ concentrations with a constant $\mathrm{pH}$ of 2 [13].

not, the pit repassivates. Initiation and repassivation events normally occur many times in pit embryos before pit propagation occurs.

(4) The methed of conducting the pitinitiation tests was found to influence the time available for sulfide dissolution to occur at a given applied potential.

(5) Finally, in cases in which changes in sulfide inclusion morphology occur, such as in hightemperature $\left(1300^{\circ} \mathrm{C}\right)$ heat treatment, other heat treatments of Type 304L, or other 300-series stainless steels, the $L_{A-M e / S}$ value is not the primary factor in determining pit-initiation resistance. The sulfide morphology and matrix compositions are the critical factors that determine the pit-initiation resistance.

\subsection{Crack Initiation at Pits Having Critical Depth}

Pits can serve as initiation sites for SCC.

Though a well-developed model for the transition from pitting to SCC has not been developed, a model for the initiation of corrosion fatigue (CF) cracks at pits does exist. In the model discussed by Hagn [14], pits are regarded as half-elliptical surface cracks since they have tiny fissures at their bottoms. The following equation was derived from linear-elastic fracture mechanics for the stress-intensity threshold, $\Delta K_{\mathrm{th}}$, required to initiate a fatigue crack at a corrosion pit.

$\Delta K_{\text {th }}=\Delta \sigma(\pi a)^{1 / 2} F(a, c)$ 
where $\Delta \sigma$ is the alternating tensile stress, $n$ is the pit depth and major axis of the ellipse, $c$ is the minor axis of the ellipse, and $F(a, c)$ is a geometric factor calculated from $a$ and $c$. The exact expression for $F(a, c)$ is

$$
F\left(a_{r} c\right)=[1.13-0.07 \sqrt{(a / c)}]+
$$

$\sqrt{1+1.47(a / c)^{1.64}}$
Equation ( 8 ) can be arranged to calculate the critical pit depth, $a_{\mathrm{th}}$.

$a_{\mathrm{th}}=(1 / \pi)\left(\Delta K_{\mathrm{th}} / F(a, f) \Delta \sigma\right)^{2}$

This relationship is illustrated in Fig. 9. The curves shown represent various stress ratios $\left(R=\sigma_{\min } / \sigma_{\max }\right)$ and aspect ratios $(a / c=0.75 \mathrm{or}$ 1.35). Though this expression was discussed in

Threshold pit/crack depth (in.)

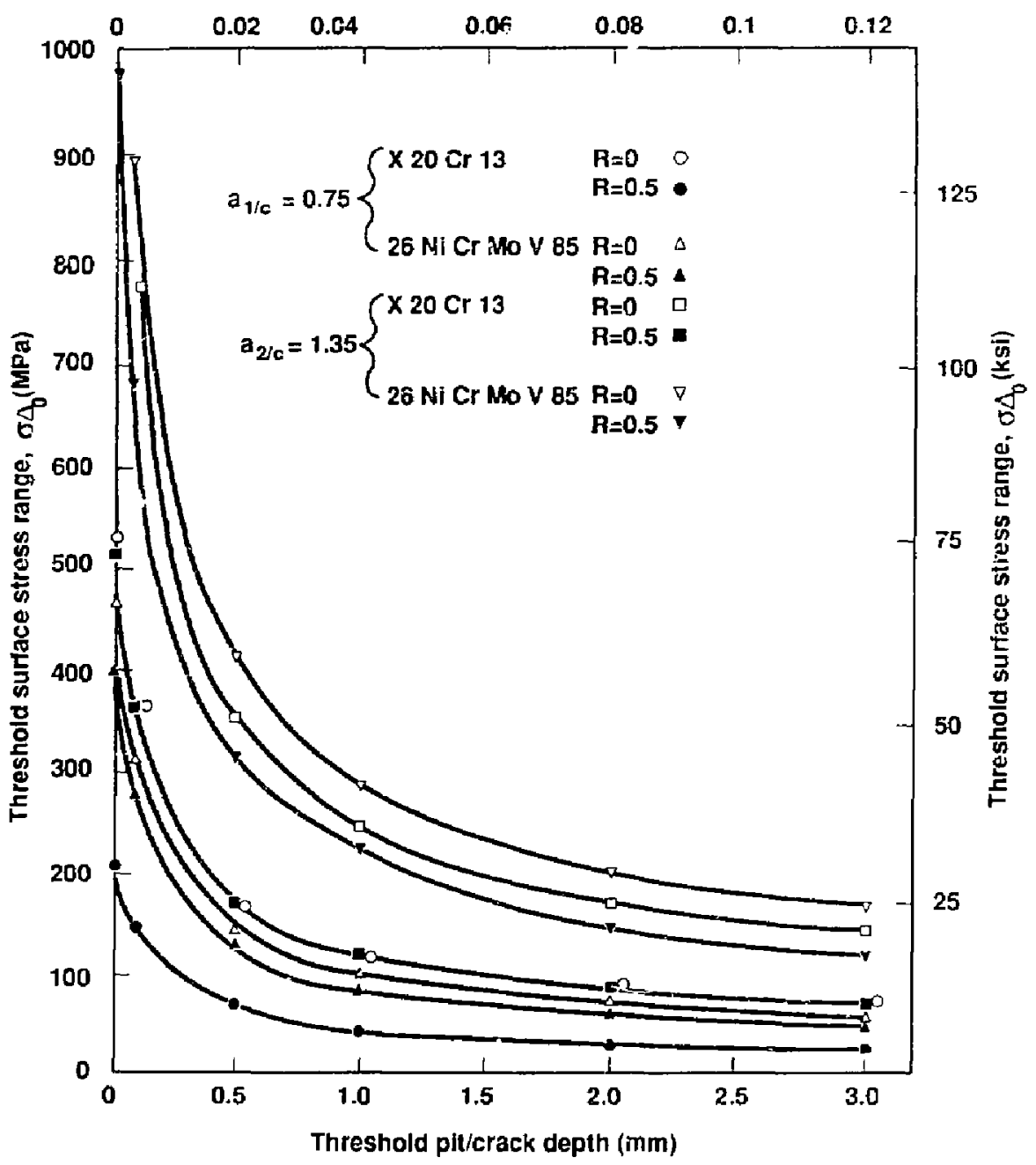

Figure 9. Relationship between stress amplitude and minimum depth of surface defects for $12 \%$ chromium steel and a $2.0 \%$ nickel-chromium-molybdenum-vanadium steel [14]. 
the context of $\mathrm{CF}$, Hagn claims that it is also applicable to SCC. Others have used linear-elastic fracture mechanics to derive an expression for the time to initiate a crack, $t_{\text {ine }}[15 j$.

$t_{\mathrm{inc}}=\frac{\kappa_{\mathrm{Iscc}}^{2} \exp \left(-v_{\mathrm{m}} / v_{0}\right)}{\pi B\left(\sigma^{2}-\sigma_{1}^{2}\right)}$

where $K_{\mathrm{ISCC}}$ is the stress-intcnsity threshold for initiation of $S C C, \sigma$ is the applied stress, $\sigma_{0}$ is the stress nected to close the crack, $B$ is a constant, $-V_{\pi 1}$ is the electrochemical potential of the sample, and $V_{0}$ is the reversible potential.

Stress corrosion crack initiation can also occur in the abscnce of pitting by intergranular corrosien or slip-dissolution processes. Intergranular-corrosion-initiated SCC requires that the local grain-boundary chemistry differ from the bulk chemistry. This condition occurs in sensitized austenitic stain]ess stecls or with the segregation of impurities such as phosphorus, sulfur, ar silicon in a varicty of materials. Slipdistolution-initiated 5 CC results from local corrosicun at emerging slip planes and occurs primatily in low-stacking-fault m.aterials. The processes of crack initiation and propagation by the slipdissolution process are very similar.

\subsection{Critical Potential for SCC Initiation in Sensitized Steels}

According to Jones, the thermodymamic conditions for anodically assisted SCC are that dissolution or oxidation ot the metal and its dissolution in the clectrolyte must be thermodynamically possible and that a protective film, such as an cxide or salt, must be thermadynamically stable [16]. Critical potentials for SCC can be determined from linear polarization curves, and these potentials can be related to priential$\mathrm{pH}$ stability diagrams (Pourbaix diagrans) because these diagrams describe the conditions at which film formation and metal oxidation will occur |17|.

Figure 10 is a schematic of the relationship existing between electrode potential and current density for poorly passivating systems and strongly passivating systems. Potentials where severe cracking susceptibility is encountered in ductile alloys exposed to aqueous environments are designated [17]. Transgranular SCC (TGSCC) occurs in Fig. 10(a) because the material is in transiti: n from active corrosion to passive film formation such that the simultaneous conditions for film formation on the crack walls and corrosion at the crack tip are met. A similar condition exists in Fig. 10(b), with the added factor that

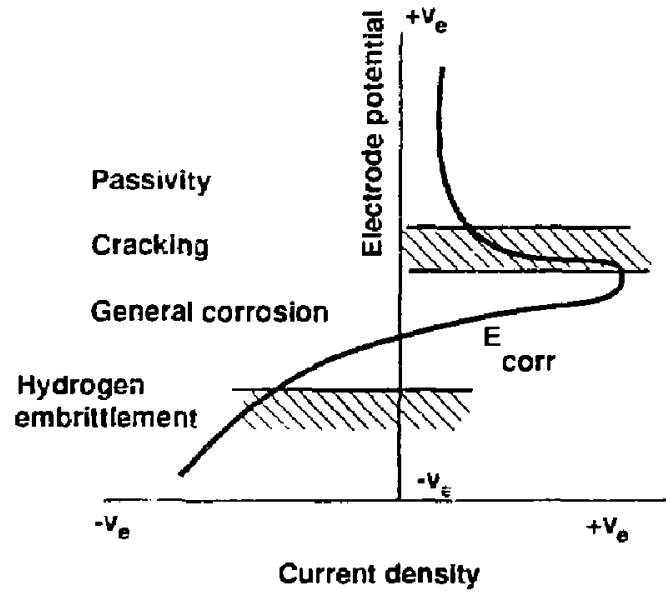

(a)

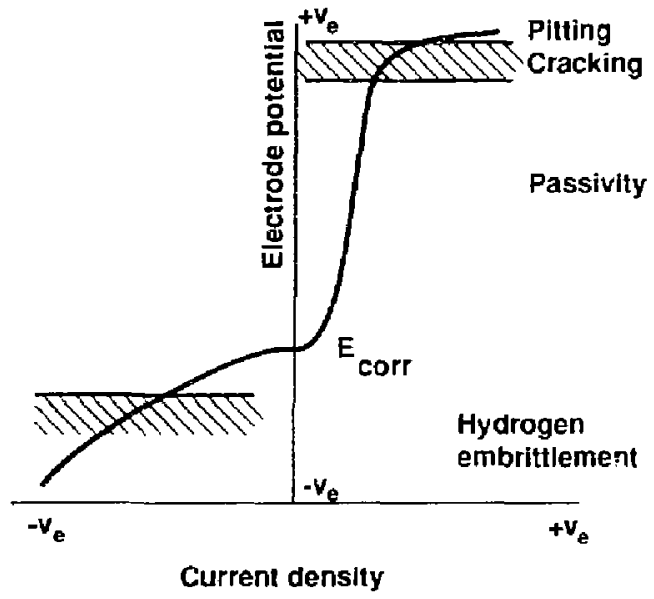

(b)

Figure 10. Electrode potential/current density relationship for (a) poorly passivating and (b) strongly passivating systems, indicating, in the two cases, where severe cracking susceptibility in ductilealloy/aqueous-environmental systems is commonly encountered [23]. 
these potentials are at or above the pitting potential, so that cracks can initiate by pilting.

Intergranular SCC (IGSCC) occurs over a wider range of potentials than those shown in Fig. 10(a) and (b) because chemical inhomogeneities at the grain boundary produce a different electrochemical response relative to the bulk material. Identification of critical potentials for SCC has led to the use of electrochemical methods for assessing stress corrosion susceptibility.

Cubicciotti and Ljungberg conducted tests that hic ve shown that ICSCC does not occur in sensitized Type 304 stainless stecl below $E_{\text {IGSCC }}$ [18]. Sensitization is defined as unusual susceptibility to IGSCC because of the precipitation of chromium carbides al grain boundaries. Such precipitation depletes the region adjacent to grain boundaries of chromium, leaving an active path for the propagation of intergranular corrosion cracks into the alloy. IGSCC can initiate at potentials, $E_{1 C S C C}$ at which the protective film is destabilized. A correlation between $E_{I G S C C}$ and the stable phase containing chromium was found. Above $E_{\mathrm{liscc}}$, the stable chromium-containing phase is $\mathrm{Cr}_{2} \mathrm{O}_{3}$. Below $E_{\mathrm{JGSCC}}$, the stable phase is $\mathrm{FeCr}_{2} \mathrm{O}_{4}$. The interpretation of this correlation is that a surface oxide phase of $\mathrm{FeCr}_{2} \mathrm{O}_{4}$ is protective against ICSCC, while $\mathrm{Cr}_{2} \mathrm{O}_{3}$ is not.

The test environment described in ASTM G-36 [19] has been of sufficient interest to prompt studies of the passive film formed in the presence of $\mathrm{MgCl}_{2}$. M. Da Cunha Belo et al. used activation amalysis and Auger electron spectroscopy to study the relationship between the critical cracking potential for SCC of stainless steels and the chemical composition of the film formed in boiling $42 \% \mathrm{MgCl}_{2}$ [20]. This analytical study showed that the complex oxide of chromium and nickel, which is formed at potentials where the steel is susceptible to SCC, contains more chromium than nickel. Conversely, the oxide is richer in nickel than chromium if it develops at potentials at which the steel is protected. This finding is inconsistent with that of Cubicciotti and Ljungberg [18]. However, alloys with a higher nickel content, which may tend to form nickelrich films, are more resistant to SCC. The effects of nickel content on SCC resistance are discussed in detail in Sec. 6.4 .

Cragnolino has determined $E_{1 \mathrm{GSCC}}$ of sensitized Type 304 stainless steel at conditions simulating normal and faulty boiling-water reactor (BWR) environments [21]. He determined the ef- fect of environmental variables such as temperature, $\mathrm{pH}$, and solution composition on the value of $E_{16 S C C}$ and on crack propagation rate. The relevance of $E_{\mathrm{ICSCC}}$ in predicting environmental conditions that lead to IGSCC is emphasized for both the current normal operating BWR environmett and that modified by the injection of hydrogen. In this context, the significance of the corrosion potential of the matcrial and the redox potential of the environment as affected by the composition of the aqueous system, in particular the concentration of reducible species, is briefly addressed. Experimental results indicate that ICSCC accurs only when $E_{\mathrm{ser}}>E_{\mathrm{ICSCC}}$.

TCSCC aleo can be prevented by maintaining the poteritial at al level bolow the critical potential. Mancia and Tamba used slow strain rale lesting (SSR: ) under potentiostatic control to deternine the potential required for cathodic protection from TCSCC in neutral and acidic $\mathrm{NaCl}$ solutions [22].

\subsection{Propagation of Cracks}

Ford has published an excellent review of the SCC litcrature [23]. From his review, he has found that mechanisms for propagation fall into one of three generat classes: (i) pre-existing active-path mechanisms, (ii) absorption-related mechanisms, and (iii) strain-assisted active-path mechanisms. In contrast, Jones classifies SCC mechanisms as either anodic or cathodic [16]. The most obvious anodic mechanism is that of simple active dissolution and removal of material from the crack tip. The most obvious cathodic mechanism is hydrogen evolution, absorption, diffusion, and embrittlement.

The breaking of the interatomic bonds at the crack tip occurs either by chemical solvation and dissolution or by mechanical fracture (ductile or brittle). Mechanical fracture includes normal fracfure processes that are assumed to be stimulated or induced by one of the following interactions between the materia! and the environment: (i) adsorption of environmental species, (ii) surface reactions, (iii) reactions in the metal ahcad of the crack tip, and (iv) surface films.

ICSCC is an example of a pre-existing activepath mechanism. Several thermodynamic models have been used to explain the role of alloy composition in serusiliation of austenitic stainless steels, which leads to ICSCC |24|. The rate of 
sensitization is limited by solid-state transport of chromium to grain boundaries, where $\mathrm{Cr}_{23} \mathrm{C}_{6}$ carbides form.

Failure caused by hydrogen embrittement at a crack tip, which can result from electrochemical hydrogen evolution, is an example of an absorption-related mechanism [25].

Finally, TCSCC is an example of a strainassisted active-path mechanism. In steels that have not been sensitized and in copper-based alloys, the most common mode of SCC failure is by TGSCC. In the case of TGSCC, it has been shown experimentally that the crack can proceed thonugh the bulk material as a scries of (passive) film rupture/repassivation steps [26]. Rupture of the pasșive film at the crack tip occurs after a period of "creep strain." When the strain in the passive film at the crack tip exceeds a critical value, the film ruptures. Then there is localized anodic dissolution of metal at the crack tip before repassivation. Temporary stress relaxation results from the crack widening. The rate of crack propagation depends on both the stress and the rates of dissolution and repassivation at the crack tip.

Dissolution and repassivation are both electrochemical processes; the rates of these processes are governed by heterogeneous reaction kinetics at the interface as well as by jon transport in the crack clectrolyte $[27,28]$.

The limiting velocity $d a / d t$ for a cJack advancing under pure anodic dissolution is given by the following Faradaic relationship:

$d a / d t=i_{a} M / 2 p F$

where $i_{\mathrm{a}}$ is the anodic current density of a bare surface, $M$ is the atomic weight $z$ is the valence, $F$ is Faraday's constant, and $\rho$ is the material density. A number of factors can reduce the crack velocity below that given by Eq. (12). The most widely examined crack growth retardation process is that resulting from the crack tip being covered by a film for some fraction of time. A typical crack is illustrated in Fig. 11.

Nakayama and Takano have applied a slip dissolution-repassivation (SDR) model to SCC of Type 304 stainless stecl in a boiling $\mathrm{MgCl}_{2}$ solution [29]. They used SSRT to demonstrate that the SCC was dependent on strain rate, applied potential, and solution temperature. This behavior was qualitatively explained by considering both the formation rate of slip steps and the characteristics of thetr dissolution-repassivation. Furthermore, they used high-voltage electron microscopy
(HVEN) to image crack tips and found that transgranular cracks propagate along active slip planes. Thus, they proved that the SDR mechanism is acceptable for describing the transgranular cracking (TGC) of Type 304 stainless steel in $42 \% \mathrm{MgCl}_{2}$ solution. An SDR model was developed which could quantitatively predict the crack propagation rate as a function of applied potential and slip-step formation tate.

Development of the SDR model begins with the expression for the dissolution current density, $i(t)$, at a crack tip for a single slip step. Note that $i(t)$ decays exponentially because of repassivation of the active surface at the crack tip.

$i(t)=f^{\circ} \exp (-\beta t)$

where $t$ is time, $\rho$ is the dissolution current density of the fresh surface at $i=0$, and $\beta$ is the decay constant. Note that $j^{\circ}$ has been observed to increase and $\beta$ has been observed to decrease with potential. The time average of the dissolution current density is calculated as shown in Eq. (14):

$$
\begin{aligned}
& \langle i\rangle=\int_{0}^{1 / n_{\mathrm{s}}} i(t) d t /\left(1 / n_{\mathrm{s}}\right) \\
& \langle i\rangle=J^{0} / \beta n_{\mathrm{s}}\left[1-\exp \left(-\beta / n_{\mathrm{s}}\right)\right]
\end{aligned}
$$

where $n_{\mathrm{s}}$ is the formation rate of slip steps. The crack propagation rate, $d a / d t$, can then be calculatcd by an expression similar to Eq. (12):

$d a / d t=M\langle i\rangle / 2 F \rho$

A more comprehensive model is presented by Andresen for the instantaneous crack growth rate, $d a / d f[30]$. His model assumes that crack advancement is due to the rupture of an anodic film at the base of the crack.

$d a / d t=\left(M Q_{r} d \varepsilon_{\mathrm{cl}^{\prime}} d t\right) /\left(z F E_{r}\right)$

where $M$ is the atomic weight, $Q_{\mathrm{f}}$ is the anodic (oxidation) charge density, $d \varepsilon_{\mathrm{ct}} / d$ t is the crack tip strain rate, $z$ is the valence, $p$ is the material density, $F$ is Faraday's constant, and $\varepsilon_{\mathrm{ct}}$ is the oxide fracture strain. Though this concept was developed for TCSCC, a linear relationship also exists between $d a / d t$ and $d \varepsilon_{c t} / d t \mid \log (d a / d t)$ vs $\log$ $\left.\left(d \varepsilon_{\mathrm{et}} / d f\right)\right\}$ for IGSCC, as illustrated in Fig. 12 [16]. The anodic processes associated with $Q_{\mathrm{f}}$ are

$M \rightarrow M^{+}+e^{-}$ 


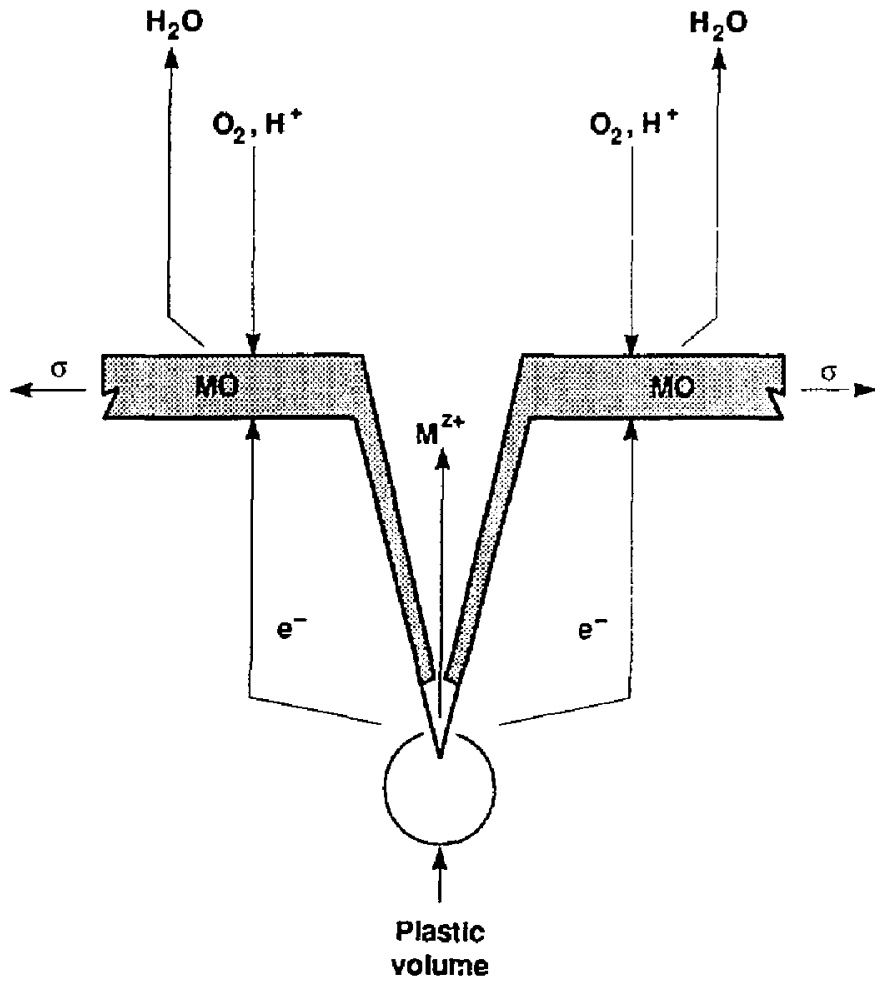

Figure 11. Illustration of propagation of a typical crack.

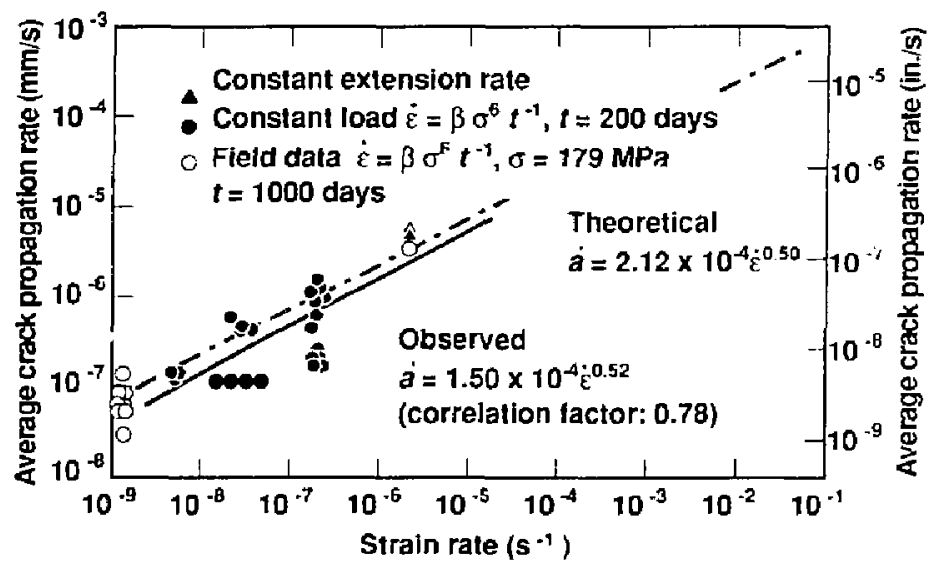

Figure 12. Comparison between observed and theoretical crack propagation rate/strain rate $(a / \varepsilon)$ relations: ip for furnace-sensitized Type 304 stainless steel in water $/ 0.2 \mathrm{ppm}$ oxygen at $228^{\circ} \mathrm{C}$ ( $\left(550^{\circ} \mathrm{F}\right)$ i16]. 
$\mathrm{M}+\mathrm{H}_{2} \mathrm{O} \rightarrow \mathrm{MO}+\mathrm{H}^{+}+\mathrm{e}^{-}$

$\mathrm{M}^{+}+\mathrm{H}_{2} \mathrm{O} \rightarrow \mathrm{MO}+\mathrm{H}^{+}$

Note that these equations represent generic reactions and are, thercfore, not balanced. The generic oxide species, $\mathrm{MO}$, could tepresent $\mathrm{Cr}_{2} \mathrm{O}_{3}$, $\mathrm{Cr}(\mathrm{OH})_{3} \mathrm{Cr}(\mathrm{OH})_{2}, \mathrm{Fe}_{2} \mathrm{O}_{3}$, or $\mathrm{Fe}_{3} \mathrm{O}_{4}$. Galvanically coupled cathedic reactions include the reduction of oxygen and hydrngen ion:

$\mathrm{O}_{2}+\mathrm{H}_{2}+\mathrm{e}^{-} \rightarrow \mathrm{OH}^{-}$

$\mathrm{O}_{2}+4 \mathrm{H}^{+}+4 \mathrm{r}^{-} \rightarrow 2 \mathrm{H}_{2} \mathrm{O}$

$2 \mathrm{H}^{+}+\mathrm{e}^{-} \rightarrow \mathrm{H}_{2}$

Note that Maicr and Galvele have used the straining metal electrode technique as an SCC test for Type 304 stainless steel in $\mathrm{NaCl}+\mathrm{H}_{2} \mathrm{SO}_{4}$ solutions 1311 . They concluded that a periodic film formation process (repassivation) does indeed occur during straining, which is consistent with the models of Nakayama and Takano [29] and Andresen [30]. Marshall and Burstein have studicd the kinetics of the repassivation process on Types 304L ard 316L in detail using a scratch technique [32]. They concluded that the repassi- vation rate is controlled by ion conduction through the growing oxide film under high slectric field.

There are several possible rate limiting steps:

(i) mass transport along the crack to the crack tip;

(ii) reactions in the solution near the crack; (iii) surface adsorption at or near the crack tip; (iv) surface diffusion; (v) surface reactions; (vi) absorption into the bulk; (vii) bulk diffusion to the plastic zone ahead of the ad vancing crack; (viii) chemical reactions in the bulk; and (ix) the rate of interatomic bond rupture [16].

In order to determine the effect of repository conditions (electrolyte film concentration, temperature, etc.) on the rate of crack propagation, it is necessary to solve the transport equations for ion transport in the crack using the heterogeneous reaction rates at the interface as boundary conditions. Since there is a term for electromigration effects, Laplace's equation must also be solved $[27,28]$. IGSCC propagation, when it occurs, can be modeled in a similar fashion. Figure 13 shows the relationship between the crack propagation rate, $d a / d i$, arid stress intensity, $K$, for different crack-tip strain rates, $d \varepsilon_{\mathrm{ct}} / d t$. At slow strain rates and low stress intensity, $d a / d t$ is controlled by film rupture and repassivation rates. As the stress intensity increases, da/dt recomes limited by transport rates in the aqueous phase [23].

\section{Data from the Literature on Pitting and SCC}

Well over 1000 articles on pitting, crevice corrosion, and SCC of the candidates have been reviewed for this report. Of those articles, the most relevant (over 200) are discussed in this report. The information for Type 304 is abundant, whereas relatively little information exists for Alloy 825. Also, note that most tests have been conducted in boiling $42 \% \mathrm{MgCl}_{2}$, solutions of $\mathrm{NaCl}$ and $\mathrm{Na}_{2} \mathrm{SO}_{4}$, seawatcr, or hol pressurized water at $288^{\circ} \mathrm{C}$. Despite the scarcity of information on the performance of Alloy 825, we were fortunate to find a few key articles which make direct comparisons of the SCC susceptibility of the austenitic candidates. One reference described comparison tests that were conducted in the presence of gamma radiation.

\section{Experimental Data on Pitting}

\subsection{Pitting Potential}

Hodgkiess and Rigas conducted a study of the corrosion resistance of several materials, including Type 316L stainless steel and Alloy 825, in scawater that had a $\mathrm{pH}$ ranging from 7.5 to 8.3 [33]. This investigation included long-term immersion tests and anodic-polarization experiments.

The results confirmed the susceptibility of Type 316 L stainless steel to LC in aerated sea water at ambient temperatures, although its performance is improved by reducing the amoun! of dissolved oxygen in the environment. This 


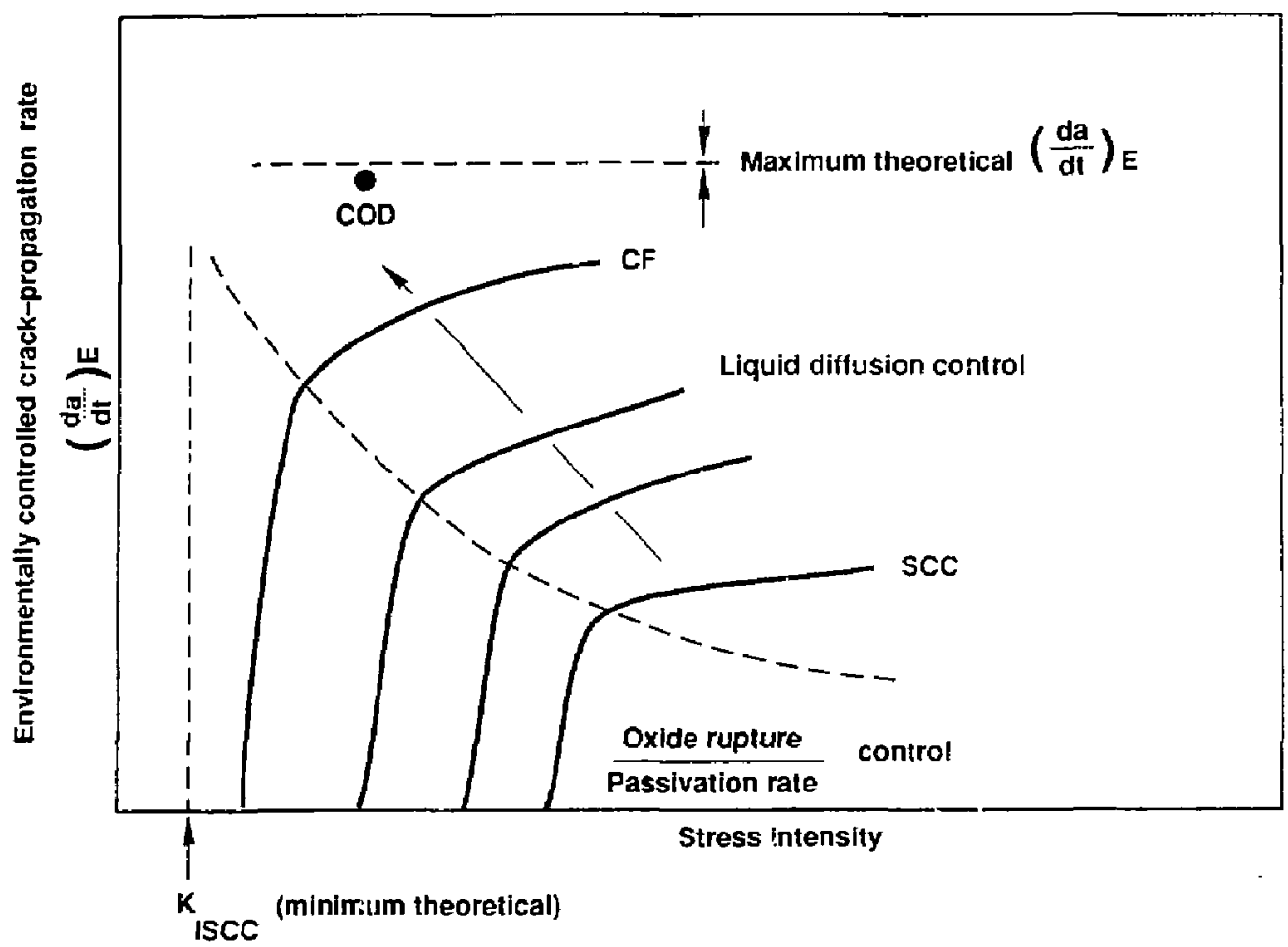

Figure 13. Schematic variation of the crack propagation rate with stress intensity for different instantaneous crack tip strain rates. Note the smooth transition between SCC and corrosion fatigue (CF) regines, associated with the different rate-determining processes [23]. COD, crack opening. displacement.

investigation also demonstrated the beneficial effect of increased chromium and molybdenum content on resistance to LC. Corrosion, pitting, and repassivation potentials for Type $316 \mathrm{~L}$ stainless steel and Alloy 825 are given in Table 1 and are compared in Figs. 14 and 15.

The difference between the pitting potential, $E_{c}$ and the corrosion potential, $E_{\text {corr }}$ serves as a quantitative measure of the susceptibility of an alloy to pitting; the grcater the difference, the greater the resistance to pitting. Similarly, the difference between the pitting potential and the repassivation potentia], $E_{\mathrm{p}}$ serves as a measure of the resistance of an alloy to crevice corrosion. These quantities are compared in Figs. 14 and 15. Though Alloy 825 and Type $316 \mathrm{~L}$ are both

Table 1. Corrosion, pitting, and repassivation potentials in aerated seawater.

\begin{tabular}{llrrrl}
\hline Alloy & $\begin{array}{c}T \\
\left({ }^{\circ} \mathrm{C}\right)\end{array}$ & $\begin{array}{c}E_{\text {corr }} \\
(\mathrm{mV})\end{array}$ & $\begin{array}{c}E_{\mathrm{c}} \\
(\mathrm{mV})\end{array}$ & $\begin{array}{c}E_{\mathrm{p}} \\
(\mathrm{mV})\end{array}$ & \multicolumn{1}{c}{ Comment } \\
\hline $316 \mathrm{~L}$ & 20 & -310 & 250 & 30 & l'its \\
& 60 & -180 & 30 & -160 & Deep pits and crevice corrosion \\
825 & 20 & -240 & 1050 & 1030 & Shallow pits and crevice corrosion \\
& 60 & -280 & 230 & 0 & Pits and crevice corrosion \\
\hline
\end{tabular}

Note: All potentials a re relative to a saturated calomel electrode (SCE). 


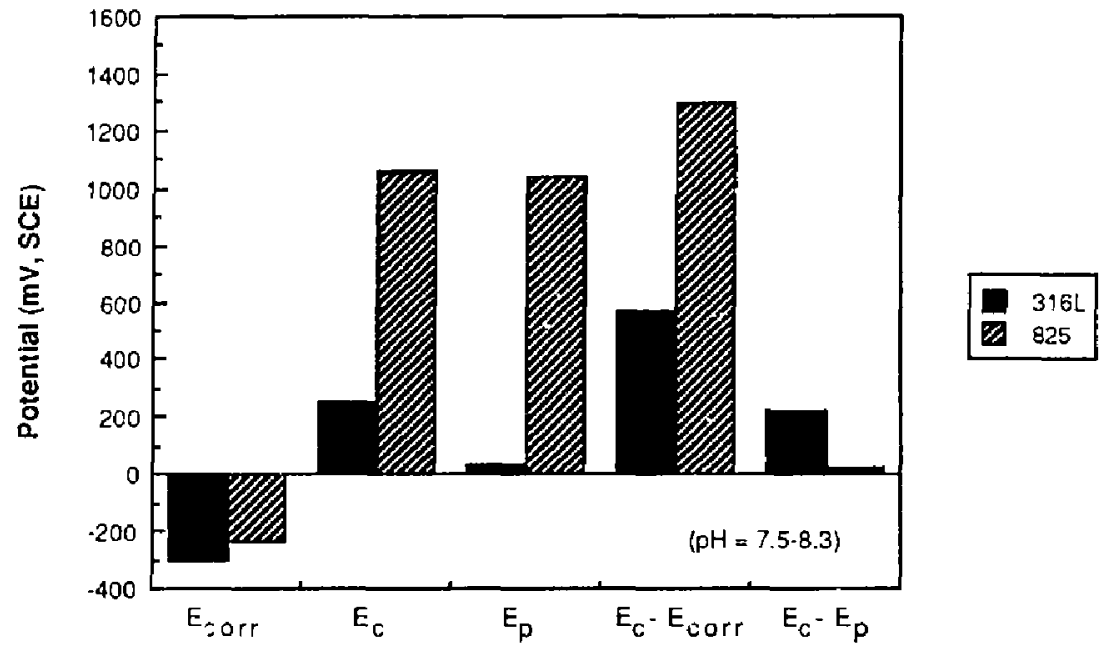

Figure 14. Corrosion potential $\left(E_{c o r r}\right)$, pitting potential $\left(E_{c}\right)$, and repassivation potential $\left(E_{\mathrm{p}}\right\}$ for Type 316L stainless steel and Alloy 825 in aerated seawater at $20^{\circ} \mathrm{C}[33]$.

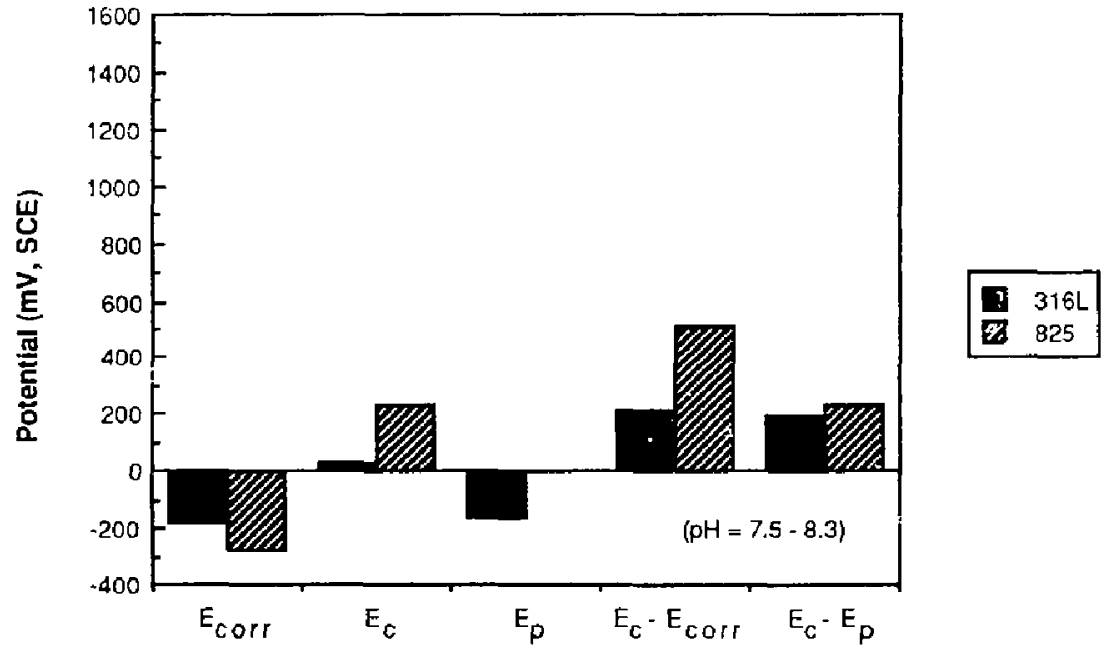

Figure 15. Corrosion potential $\left(E_{\text {corr }}\right)$, pitting potential $\left(E_{c}\right)$, and repassivation potential $\left(E_{p}\right)$ for Type 316L slainless steel and Alloy 825 in aerated seawater at $60^{\circ} \mathrm{C}[33]$. 
susceptible to pitting and crevice corrosion in seawater, Alloy 825 appears to be more resistant to pitting than Type 376L.

Scarberry et al. have used slow- and rapidscan potentiodynamic techniques, scratch techniques, and immersion tests to study the pitting of Types 304 and 316 stainless steels, Alloy 825, and Alloy 625 (Inconel) in occan water at approximately $30^{\circ} \mathrm{C}$, nondeacrated and saturated with $\mathrm{SO}_{2}$ [34]. Substitute occan water was prepared for testing by ASTM Procedure D1141-52 (without heavy metals). Specimens for potentiodynamic tests were sanded with 120 -grit aluminum oxid: sandpaper and had surface areas of $71070 \mathrm{~cm}^{2}$, whereas specimens for constant-potential and scratch tests were sanded to 500 -grit. Scan rates for slow-and rapid-scan potentiodynamic tests were 0.6 and $50 \mathrm{~V} / \mathrm{hr}$, respectively. Scratch tests were conducted with a silicon carbide stylus.

During the immersion tests, it was found that Type 316 stainless sted and Alloy 825 showed only incipient pitting. Alloy 625 was not attacked. Incipient pits are defined here as pinpoint areas of attack, without measurable depth, surrounded by a thin layer of corrosion product. In the $\mathrm{SO}_{2}$ saturated substitute ocean water, Types 304 and 316 stainless steels immediately showed a high density of pits. The pits then grew together, producing a thick layer of black corrosion product. This was followed by severe general corrosion beneath the surface layer. Alloy 825 suffered severe pitting, but not general attack. Alloy 625 was not attacked.
Anodic curves determined by rapid-scan potentiodynamic tests for deacrated and $\mathrm{SO}_{2}-$ saturated substitute ocean water are shown in Figs. 16 and 17, respectively. The classical effect of increasing molybdenum content upon the width of the passive region is evident in Fig. 16. The curves gencrated during the rapid-scan tests illustrate the close proximity of the corrosion and pilting potentials of Types 304 and 316 stainless stec]s. From these results, it is concluded that these two 30)-series stainless stecls are likely to pit. In contrast. Alloy 825 would be expected to exhibit only marginal pitting behavior, whetcas Alloy to25 would not to expected to pit.

Quantitative results of the potentiodynamic and scratch tests are summarized in Tables 2(a) anc if for deacrated and $\mathrm{SO}_{2}$-saturated substitute occan water, respectively. Again, recall that the more positive the difference $E_{c}-E_{\text {corr }}$ the more resistant an alloy is to pitting. Negative numbers indicate that pitting occurs readily at the corrosion potential. Based upon this criterion, the ranking of the four alloys considered by Scarberty is: Type 304 (lecast resistant) < Type $316<$ Alloy $825<$ Alloy 625 (most resistant). This ranking is identical for both deacrated and $\mathrm{SO}_{2}$ solutions and is consistent with results from the immersion tests. However, the $\mathrm{SO}_{2}$-saturated solution was more aggressive than the deaerated solution. Alloy 625 was included since it is often used as a weld metal for Alloy 825 . The data from Tables 2(a) and (b) are compared graphically in Figs. 18 through 21.

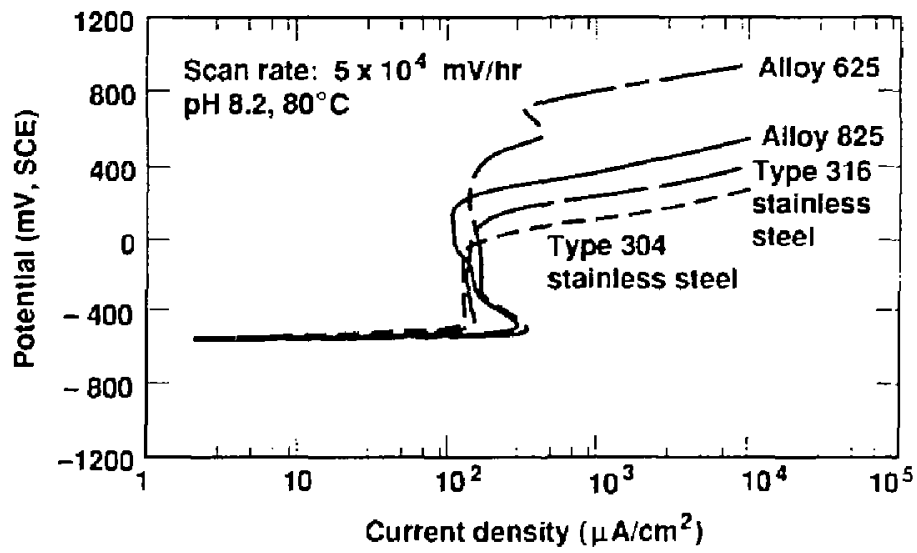

Figure 16. Anodic polarization curves for deaerated, substitute ocean water [34]. 


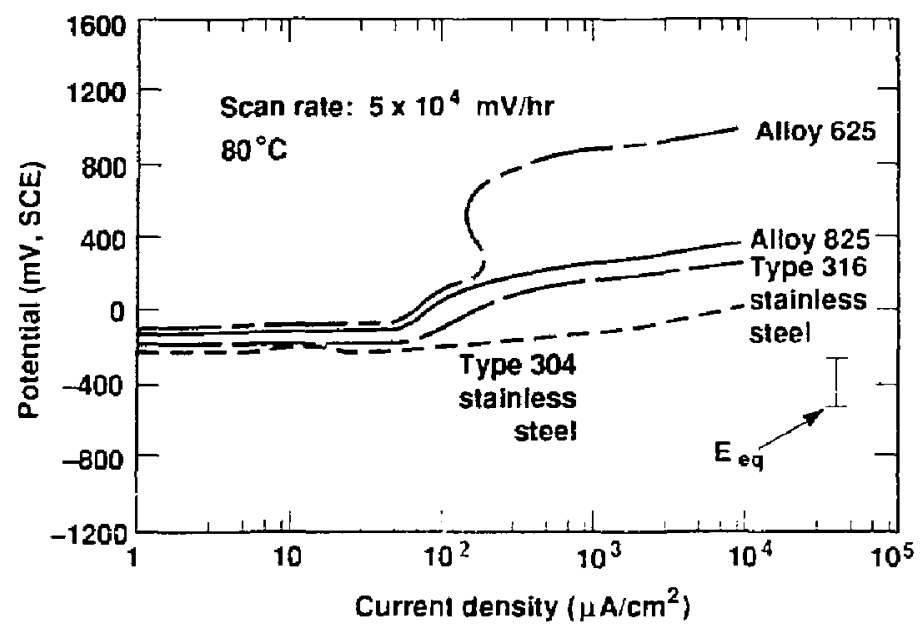

Figure 17. Anodic curves for $\mathrm{SO}_{2}$-saturated, substitute ocean water [34].

Fratesi has made a statistical estimate of the pitting potential of Type $316 \mathrm{~L}$ stainless steel in $3.5 \% \mathrm{NaCl}[35]$. Two types of experiments were performed, one series based upon a potentiodynamic lechnique with a scan rate of $10 \mathrm{mV} / \mathrm{min}$ and a second serics based upon a potentiostatic scratch technique. Application of the statistical method to the results confirmed that for each set of tests, the scattering of the pitting-potential val. ues could be related to the stochastic nature of the pasure-film failure in a given medium.

However, the notable differences in the pitting petentials obtained by the scratch method for the surlace under polentiostatic polarization in aerated and deacrated solutions suggested that the mechanical damage of the passive film was more serisus than that occurring spontaneously at the dcfective sites as a result of the medium's aggressiveness at the pitting potential. Results are summarized in Table 3.

Note the tremendous effect that deaeration of the $3.5 \% \mathrm{NaCl}$ solution (similar to seawater) has on the resistance to pitting, quantified as the difference $E_{c}-E_{\text {corr }}$ Samples in aerated solutions are more likcly to pit than samples in deacrated water, in large part because of the effect of oxygen on the currosion potential, $E_{\text {corr }}$ These measurements indicate that Type $316 \mathrm{~L}$ is more resistant to pitting than the Type 316 samples studied by Scarberry et al. However, as Fratesi points out, there is a large statistical variation in such measuremints.
Manning et al. studied the etfect of potential scan ratc on the pitting potential determination of several high-performance alloys in a solution of $4 \% \mathrm{NaCl}$ and $0.01 \mathrm{M} \mathrm{HCl}$ at $\mathrm{pH} 2$ and $70^{\circ} \mathrm{C}\{13\}$. The materials investigated included Type 316 stainless steel (austenitic), Ferralium 255 alloy (duplex), 20Cb-3 and Haynes 20-Mod alloys (super stainless), Alloy 825, and Alloy $G$ (Hastelloy G).

Rectangular test specimens were cut from a $0.64-\mathrm{cm}$ plate and were $1.3 \times 7 \mathrm{~cm}$ in dimension. The specimens were ground with 220-grit paper, degrcased in boiling acetone, rinsed with deionized water, and immediately placed in the test cell.

Threc types of pitting tests were employed in this particular study. The majority of the experiments were potentiodynamic pitting tests, which were initiated at $-300 \mathrm{mV}$ vs SCE (cathodic potential for all alloys examined) after a 2-min time period at the corrosion potential. The potential was scanned in the noble direction linearly with time at various rates, including $0.36,0.72,1,5,20$ and $50 \mathrm{~V} / \mathrm{hr}$. Results for selected alloys at two scan rates that are roughly comparable to those used by Scarberry et al. are given in Table 4 . Unfortunately, corrosion potentials are not given, so the difference $E_{\mathrm{c}}-E_{\mathrm{ear}}$ cannot be calculated.

Errors represent $95 \%$ confidence limits. From these data, it is concluded that Alloy 825 requires a more anodic potential for pitting than does Type 316 stainless sted. Galvanic coupling to a 
Table 2(a). Corrosion and pitting potentials (mV, SCE) for deaerated substitute ocean water $\left(80^{\circ} \mathrm{C}\right.$, pH 8.2),

\begin{tabular}{|c|c|c|c|c|c|}
\hline Alloy & Test & $\begin{array}{c}E_{\mathrm{c}} \\
(\mathrm{mV})\end{array}$ & $\begin{array}{l}E_{\mathrm{corr}} \\
(\mathrm{mV})\end{array}$ & $\begin{array}{c}E_{\mathrm{c}}-E_{\mathrm{com}} \\
(\mathrm{m} V)\end{array}$ & Immersion test \\
\hline 304 & FS & -300 & -53 to -115 & -247 to -185 & Pitted \\
\hline 316 & FS & -185 & -30 to -8 & -155 to -177 & Heavy incipient pitting \\
\hline 825 & FS & -40 & -42 to -35 & $210-5$ & Incipient pitting \\
\hline 625 & FS & 630 & -35 to -10 & 665 to 640 & No pitting \\
\hline 304 & SS & -202 & -115 to -53 & -87 to -149 & Pitted \\
\hline 316 & SS & -205 & -30 to -8 & -175 to -197 & Heavy incipient pitting \\
\hline 825 & SS & 40 & -42 to -35 & 5 to -2 & Incipient pitting \\
\hline 625 & SS & 260 & -35 to -10 & 22510250 & No pitting \\
\hline 304 & ST & -70 & -115 to -53 & 45 to -17 & Pitted \\
\hline 316 & ST & 0 & -30 to -8 & 30 to 8 & Heavy incipient pitting \\
\hline 825 & $\mathrm{ST}$ & 260 & -42 to -35 & 218 to 225 & Incipient pitting \\
\hline 625 & $\mathbf{S T}$ & None & -35 to -10 & None & No pitting \\
\hline
\end{tabular}

Note: FS = fast scan; SS = slow scan; ST = scratch lest.

Table 2(b). Corrosion and pitting potentials (mV, SCE) of substitute ocean water $\left(80^{\circ} \mathrm{C}\right.$ ) ihat is saturated with $\mathrm{SO}_{2}$.

\begin{tabular}{rrrrrrl}
\hline Alloy & Test & $\begin{array}{r}E_{\mathrm{c}} \\
(\mathbf{m V})\end{array}$ & \multicolumn{2}{c}{$\begin{array}{c}E_{\text {corr }} \\
(\mathbf{m V})\end{array}$} & $\begin{array}{c}E_{\mathrm{c}}-E_{\text {carr }} \\
\text { (mV) }\end{array}$ & Immersion test \\
\hline 304 & FS & -130 & -80 to -10 & -50 to -120 & Pitted \\
316 & FS & 10 & -140 to -80 & 150 to 90 & Pitted \\
825 & FS & 40 & -100 to -60 & 140 to 100 & Pitted \\
625 & FS & 620 & -30 to -10 & 630 to 650 & No pitting \\
304 & SS & -268 & -80 to -10 & -148 to -254 & Pitted \\
316 & SS & -60 & -140 to -80 & 20 to -80 & Pitted \\
825 & SS & 70 & -100 to -60 & 170 to 110 & Pitted \\
625 & SS & 440 & -30 to -10 & -410 to -430 & No pitting \\
304 & ST & -230 & -80 to -10 & -150 to -220 & Pitted \\
316 & ST & -130 & -140 to -80 & 10 to -50 & Pitted \\
825 & ST & -130 & -100 to -60 & -30 to -70 & Pitted \\
625 & ST & None & -30 to -10 & None & No pitting \\
\hline
\end{tabular}

Note: $\mathrm{FS}=$ fust scan; $\mathrm{SS}=$ slow scan; ST = scratch test. 

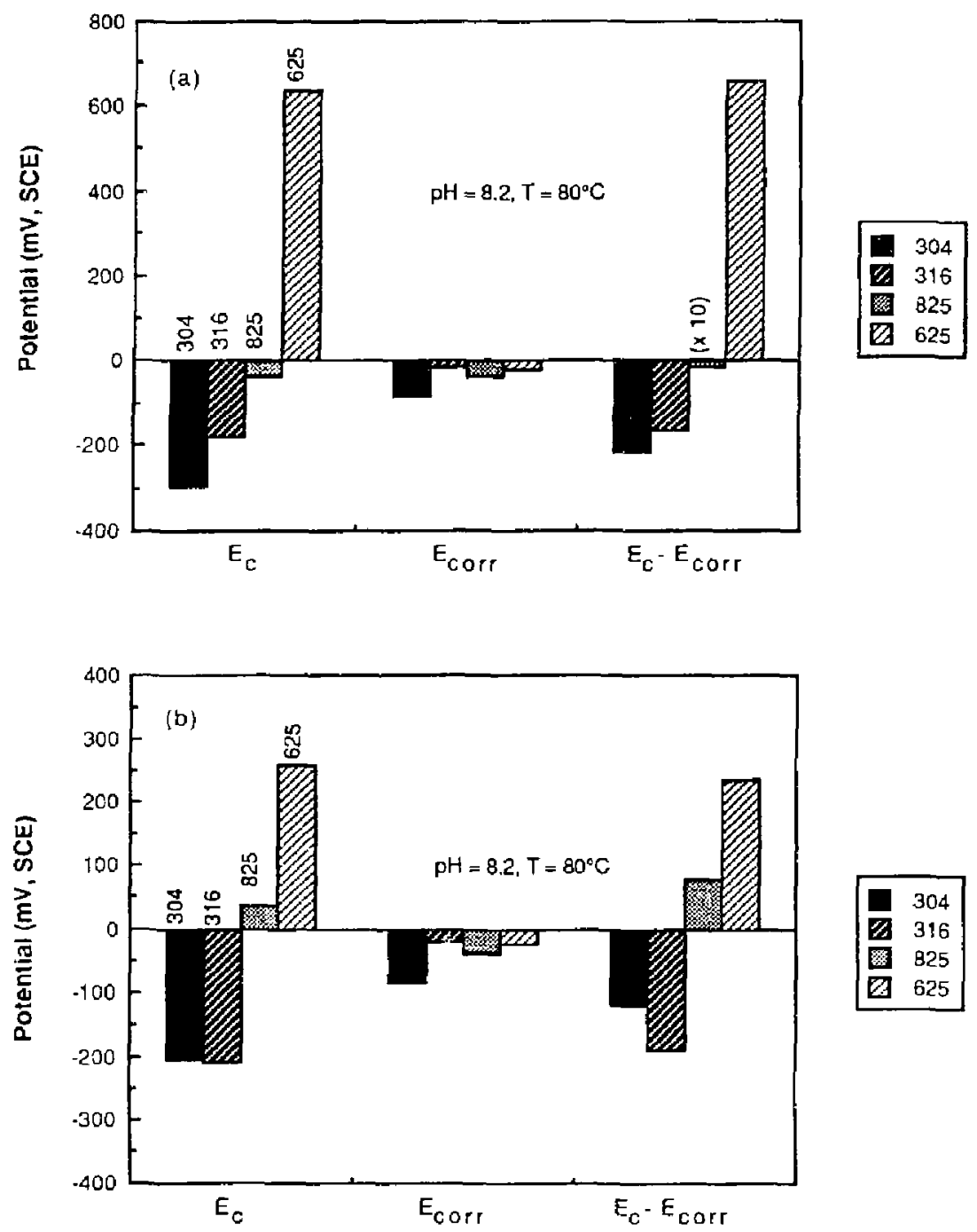

Figure 18. Pitting potential $\left(E_{c}\right)$ and corrosion potential $\left(E_{\text {corr }}\right)$ of candidate materials for (a) fast, and (b) slow scan tests in deaerated substitute ocean water [34].

noble mctal or alloy would induce pitting in Type 316 more easily than in Alloy 825 . Manning et al. also used clectron microscopy and energydispersive $x$-ray spectroscopy to study points of pit initiation on the metal surface. Frequently, pits begar it inclusions in the base metal. The compositions of the inclusions responsible for pit initiation in the various alloys are summarized in Table 5

Pitting and the onset of concomitant SCC can be prevented by controlling the potential at a level cathodic of the pilting potential. Newman 


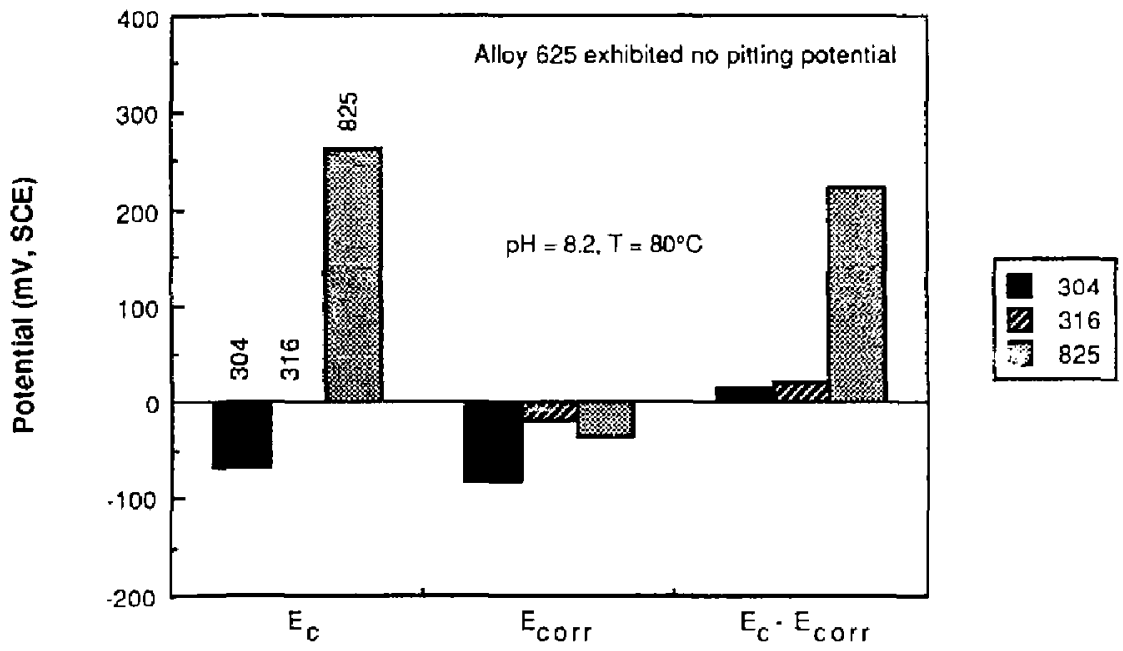

Figure 19. Pitting potential $\left(E_{c}\right)$, and corrosion potential $\left(E_{c \cap r}\right)$, of candidate materials for scralch tests [34].

and Franz have studied this aspect of pitting extensively and have determined the protection potential for pitting, $E_{p p}$, for Type 304 stainless steel in $1 \mathrm{M} \mathrm{NaCl}$ with 0.04 sodium thiosulfate added to stabilize pit growth [36]. They observed that instantaneous pit current varied roughly linearly with potential above $-200 \mathrm{mV}$, SCE. Abrupt repassivation occurred at potentials less than or equal to $E_{p p}$ (-245 mV, SCE). Their measurements were consistent with other publjshed results that they cited.

Mancia and Tamba have found that the conditions for the prevention and control of LC (pitting and SCC) of Type 304 stainless steels in chloride-containing water can be defined by means of diagrams of experimental electrode potential, $E$, vs $\mathrm{NaCl}$ concentration [3\%]. The validity of the diagrams was checked by means of long-term tests carried out under controlled conditions (in a laboratory loop and in neutral seawater) on precorraded and nonprecorroded specimens provided with erovice geometry. The prevention of SCC was studied by means of slow strain rate tesLS (SSRTS) performed either at the Irec corrosion potential or at an imposed poten- tial. The existence was established of a range of potentials within which LC propagation is stopped by a deactivation mechanism while the free surface of the stainless steel remains passive; this type of protection is termed "cathanodic."

\subsection{Pit Depths}

As will be evident from subsequent discussion, SCC can begin at pits once the pits have penetrated the base nutal sufficiently. Therefore, a correlation exists betwcen SCC initiation and pit depth. Lichti et al. conducted a test program to assess the SCC and pitting corrosion of several engineering alloys, including Types 304 and $316 \mathrm{~L}$ slainless steels, Alloy 825. Alloy 625, and Alloy C-276 (Hastolloy) [38].

In the work of Lichti et al, heated U-bends $\left(100^{\circ} \mathrm{C}\right)$ were exposed to a drip solution of geothermal condensate with 30 to $70 \mathrm{ppm}$ chloride. The test was intended to simulate running conditions on the outside of a hot off-gas discharge pipe located within a natural-draft conling 

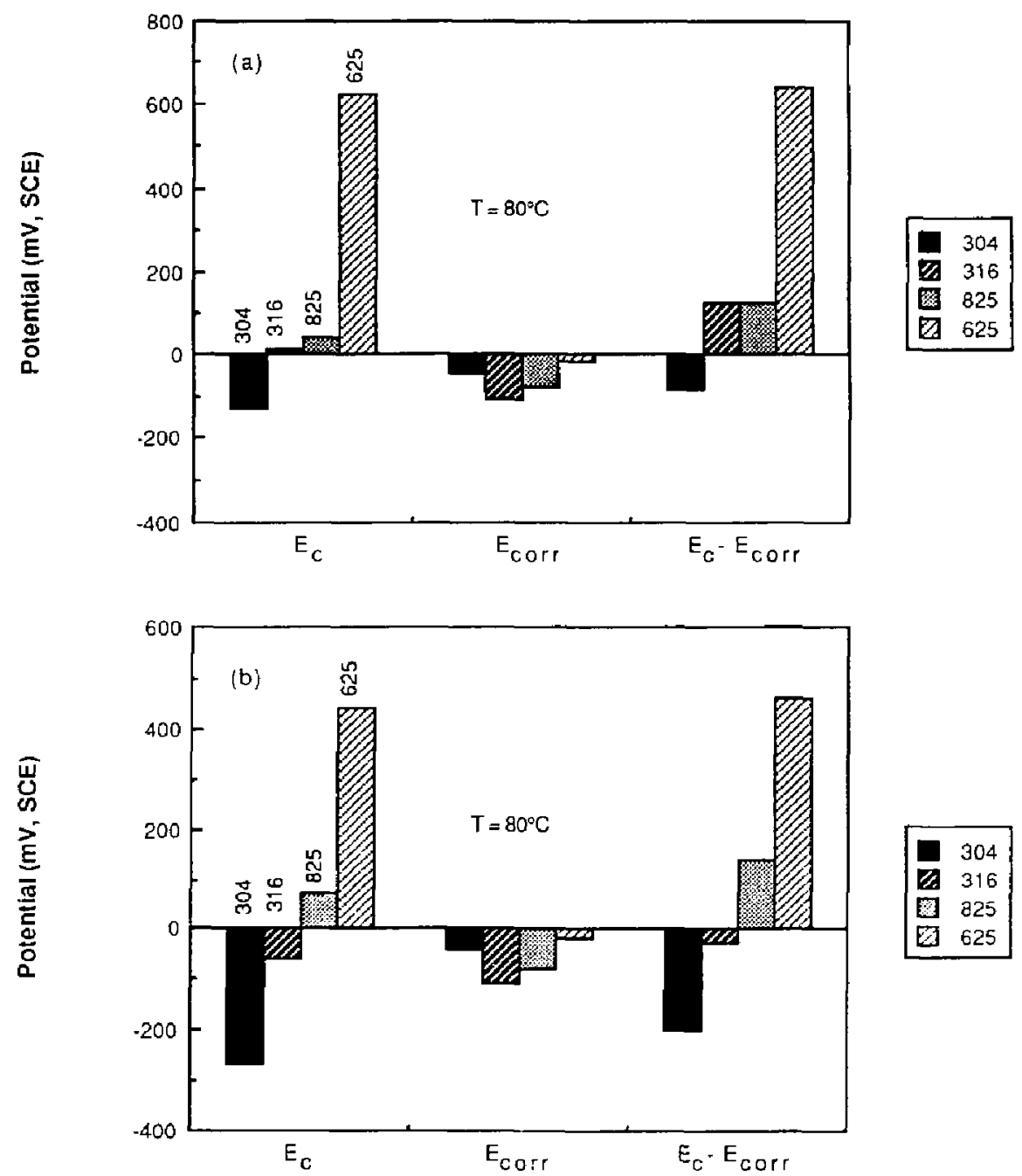

Figure 20. Pitting potential $\left(E_{\mathrm{c}}\right)$ and corrosion potential $\left(E_{\text {corr }}\right)$ of candidate materials for

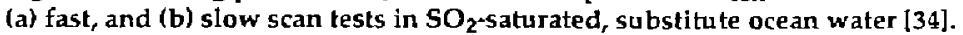

tower, and shutdown conditions in a steam transmission pipeline. The composition of the drip fluid included $200-1400 \mathrm{ppm} \mathrm{CO}_{2}, 50-200$ ppm $\mathrm{HCO}_{3}, 10-75$ ppm H2 $\mathrm{S}, 1-10$ ppm HS, 30-40 ppm $\mathrm{NH}_{4}, 0.2 \mathrm{ppm} \mathrm{Fe}, 1-20$ ppm $\mathrm{SO}_{4},<1$ ppm
$\mathrm{SiO}_{2}$, and $30-70 \mathrm{ppm} \mathrm{Cl}$. This solution was maintained at $\mathrm{pH} 5-6$ and $10-20^{\circ} \mathrm{C}$. For the austenitic alloys tested, resistance to pitting corrosion improved with increasing molybdenum conlent. Iron-nickel based alloys of low molybdenum 


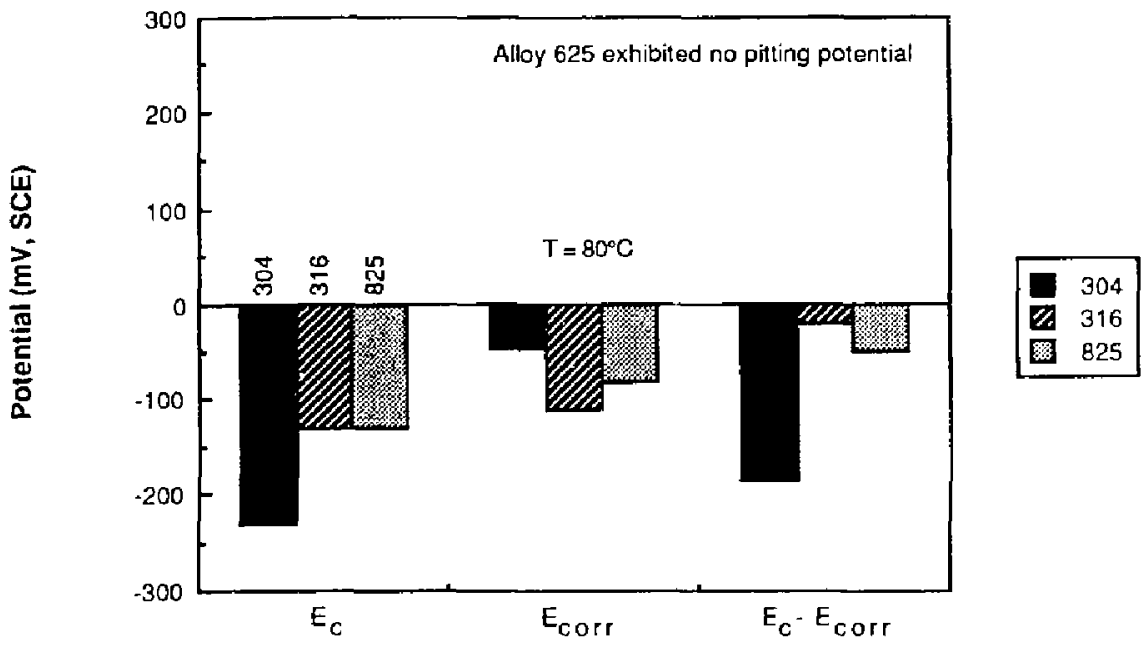

Figure 21. Pitting potential $\left(E_{\mathbf{c}}\right)$ and corrosion potential ( $\left.E_{\text {corr }}\right)$ of candidate materials for scratch tests in $\mathrm{SO}_{2}$-saturated, substitute ocean water [34].

Table 3. Corrosion and pitting potentials (mV, SCE) for Type 316L stainless steel in $3.5 \% \mathrm{NaCl}$.

\begin{tabular}{llcrc}
\hline Medium & \multicolumn{1}{c}{ Surface } & $\begin{array}{c}E_{\text {corr }} \\
(\mathrm{mV})\end{array}$ & $\begin{array}{c}E_{c} \\
(\mathrm{mV})\end{array}$ & $\begin{array}{c}E_{\mathrm{c}}-E_{\text {cor }} \\
\text { (mV) }\end{array}$ \\
\hline Aerated & Passivated only & 138 & 319 & $\mathbf{1 8 1}$ \\
Deaerated & Passivated only & -128 & 309 & 437 \\
Aerated & With emery polish & -135 & 50 & 185 \\
Deaerated & With emery polish & $-\mathbf{2 4 0}$ & 232 & 472 \\
\hline
\end{tabular}

Table 4. Average pitting potentials of several materials.

\begin{tabular}{lcccc}
\hline & & \multicolumn{3}{c}{$E_{\mathrm{c}}(\mathrm{mV}, \mathrm{SCE})$} \\
\cline { 2 - 5 } Alloy & Heat & $0 \mathrm{~V} / \mathrm{hr}$ & $0.36 \mathrm{~V} / \mathrm{hr}$ & $50 \mathrm{~V} / \mathrm{hr}$ \\
\hline 316 & 1 & -100 to -80 & $-94 \pm 28$ & $-\mathbf{1 4 7} \pm 71$ \\
825 & 1 & 160 to 180 & $209 \pm 36$ & $1 \pm 30$ \\
825 & 2 & 140 to 160 & $178 \pm 43$ & None \\
$20-$ Mod & 1 & 180 to 200 & $236 \pm 36$ & $276 \pm 33$ \\
$20-$ Mod & 2 & 260 to 280 & $321 \pm 32$ & None \\
G & 1 & None & None & None \\
\hline
\end{tabular}


Table 5. Energy-dispersive $x$-ray spectroscopy of inclusions responsible for pit initiation.

\begin{tabular}{ll}
\hline Alloy & Elements detected in inclusion \\
\hline 316 & $\mathrm{Ti}, \mathrm{Mn}, \mathrm{S}, \mathrm{Cr}, \mathrm{Si}$ \\
825 & $\mathrm{Ti}, \mathrm{V}$ \\
$20-$ Mod & $\mathrm{Ti}, \mathrm{V}$ \\
\hline
\end{tabular}

content, which included Alloy 825 , were subject to pitting corrosion but did not show cracking. The high-iron-nickel based alloys, which included Alloy C-276, were immune to all types of localized attack in the test environment. Results are summarızed in Table 6 and Fig. 22.

The ASM Metals Handbook also gives data on pit depths in Type 304, Type 316L, and Alloy 825 after approximately 6 months of exposure to chloride-containing environments [39]. Results are summarized in Table 7 and Fig. 23. Note that Type 316L and Alloy 825 are slightly better than Type 304; a representative penetration rate for piting of these alloys is approximately $1 \mathrm{~mm} / \mathrm{yr}$ $01000 \mu \mathrm{m} / \mathrm{yr})$.

\subsection{Effect of Molybdenum Content on Pitting}

Asphahani has conducted an extensive study on the LC of high-perlormance alloys [40]. The potentiostatic polarization method of testing appears 10 be the most promising in that it defines the damaging potential range in which localized corrosive attack occurs. The dependency of this potential range on temperature, $\mathrm{pH}$, chloride ion concentration, and molybdenum content was examined. The alloys studied included Type 316 stainless steel (bench mark), Alloy 825, Alloy 625, Alloy G, and Alloy C-276.

Immersion tests were conducted on flat specimens prepared from mill-annealed stock. Smooth specimens had dimensions of approximately $5 \times 2.5 \times 0.3 \mathrm{~cm}$. Specimens with artificial crevices had dimensions of approximately $7.5 \times 2.5 \times 0.3 \mathrm{~cm}$. The specimens had saw-cuk cdges and were dry-polished with fast-cut resin cloth prior to testing. Electrochemical tests were conducted on cylindrical specimens $(1.3 \times 1.3 \mathrm{~cm})$ that were saw-cut from annealed rods, wetpolished with 120-grit silicon carbide paper, and degreased in acetone. Immersion tests were performed in different environments at ambient and clevated temperatures.

The cortosion rates of the smooth and the creviced specimens were negligible after a 96-hr exposure in a neutral $4 \% \mathrm{NaCl}$ environment. No localized corrosive attacks were seen, not even on the creviced specimens exposed at $70^{\circ} \mathrm{C}$.

However, in an acidic-oxidizing solution consisting of $7 \%$ by volume $\mathrm{H}_{2} \mathrm{SO}_{4} 3 \%$ by volume $\mathrm{HCl}$, $1 \% \mathrm{CuCl}_{2}$, and $1 \% \mathrm{FeCl}_{3}$, the Type 316 and Alloy 825 specimens suffered pitting attack within less than 1 day of exposure at ambient temperature without the need of an artificial crevice to initiate the attack.

The susceptibilities of Alloy $G$ and Alloy 625 alloys to LC in this solution were temperaturedependent. Alloy $G$ performed well up to about $70^{\circ} \mathrm{C}$. Localized corrosive attack was induced on Alloy 625 at about $102^{\circ} \mathrm{C}$ within the 24 -hr exposure. At moderate temperatures, the resistance was a function of cold work; as low as $10 \%$ cold work rendered this alloy susceptible to LC at $70^{\circ} \mathrm{C}$. Finally, alloy $\mathrm{C}-276$ showed excellent resistance regardless of the testing environment, the tempcrature, and the amount of cold work.

Constant-potential tests were conducted in $4 \% \mathrm{NaCl}$ and in $3.8 \% \mathrm{FeCl}_{3}$ solutions at room temperature and at $70^{\circ} \mathrm{C}$. The results are summarized in Fig. 24. Clearly, the potential required for localized attack becomes more positive with increasing molybdenum content. From these experiments, it is obvious that there is a direct corrclation between the molybdenum content of an alloy and its resistance to localized attack. A ranking of these alloys for resistance to pitting corrosion at the conditions described is: Type 316 stainless sted (worst) < Alloy $825<$ Alloy $C<$ Alloy $625<$ Alloy C-276.

Clearly, the molybdenum content of stainless steels enhances their resistance to LC. Yu et al. studied the structure and chemical composition of the oxide film, before and after SCC, on Types 316 and 321 stainless steels corroded in hightemperature and high-pressure water containing $2000 \mathrm{ppm} \mathrm{Cl}^{-}$and $8 \mathrm{ppm}$ dissolved oxygen [41]. The methods used werc CEMS (conversion 
Table 6. Pitting and SCC in heated U-bends.

\begin{tabular}{|c|c|c|c|}
\hline Alloy & $\begin{array}{c}\text { Exposure } \\
\text { (wk) }\end{array}$ & $\begin{array}{l}\text { Max. pit depth } \\
(\mu \mathrm{m})\end{array}$ & Comment on cracking \\
\hline \multirow[t]{3}{*}{304} & 3 & 290 & Branched cracking in all samples \\
\hline & 6 & 140 & \\
\hline & 8 & 216 & \\
\hline \multirow[t]{3}{*}{$316 \mathrm{~L}$} & $\mathbf{3}$ & 161 & Branched cracking in all samples \\
\hline & 6 & 123 & \\
\hline & 9 & 145 & \\
\hline \multirow[t]{3}{*}{825} & 1 & 147 & Not detected \\
\hline & 9 & 137 & \\
\hline & 15 & 208 & \\
\hline 625 & 9 & None & Not detected \\
\hline C.276 & 9 & None & Not detected \\
\hline
\end{tabular}

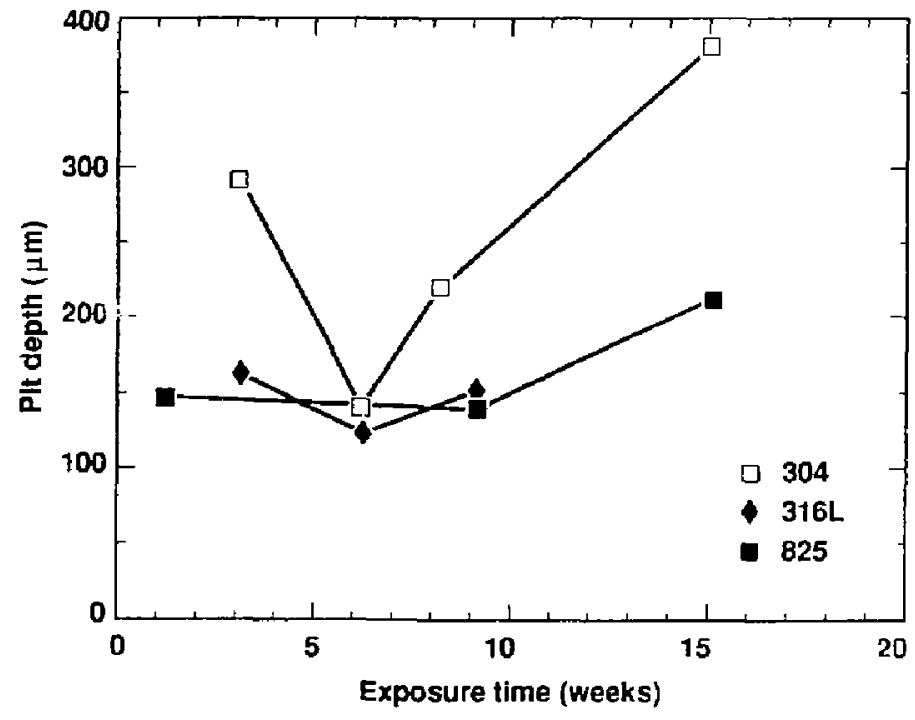

Figure 22. Pit depth for heated U-bends exposed to a geothermal condensate [38].

electron Mossbauer spectroscopy), AES (Auger electron spectroscopy), and XPS ( $x$-ray photoelectron spectroscopyl. In this study, a correlation was established between the structure and chemical composition of the oxide film and SCC resistance. Experimental results showed that the alloying element molybdenum reacted with the corrosive medium to form the $\mathrm{Fe}_{2}\left(\mathrm{MoO}_{4}\right)_{3}$ 
Table 7. Depth of pits on stainless steel spool test specimens in a flue-gas desulfurization system after 6 months of exposure ( 39 days on bypass).

\begin{tabular}{|c|c|c|c|c|c|c|}
\hline Allay & Environment & pH & $\begin{array}{l}\text { Temp } \\
\left({ }^{\circ} \mathrm{C}\right)\end{array}$ & $\begin{array}{c}\mathrm{Cl}^{-} \\
(\mathrm{ppm})\end{array}$ & $\begin{array}{c}\text { Pit depth } \\
(\mathrm{mm})\end{array}$ & Density \\
\hline 304 & a & 4.4 & 60 & 100 & 1.19 & Profuse \\
\hline $316 \mathrm{~L}$ & & & & & 0.58 & Profuse \\
\hline 825 & & & & & 0.66 & Profuse \\
\hline 304 & b & $1-2$ & $60-170$ & 7000 & 1,24 & Profuse \\
\hline $316 \mathrm{~L}$ & & & & & 0.91 & Profuse \\
\hline 825 & & & & & 0.74 & Profuse \\
\hline
\end{tabular}

a Quencher spray header above a 7000-ppm Cl${ }^{-}$slurry.

$b$ wevdry inlet duct.

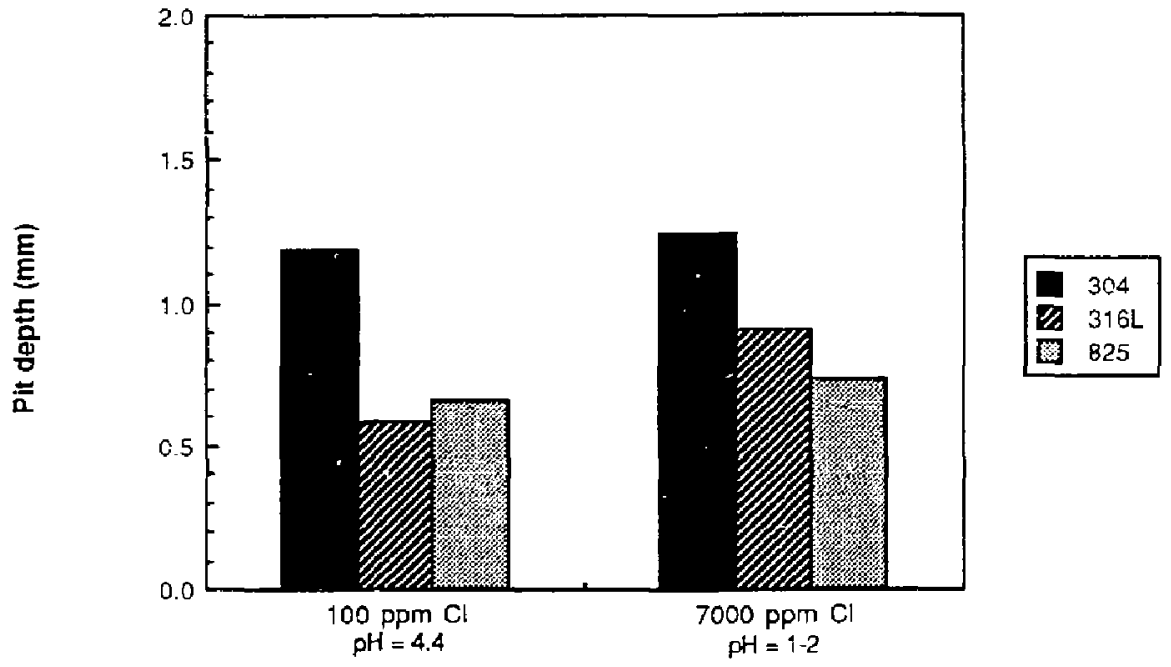

Figure 23. Pit depths in Types 304 and 316L stainless steels and in Alloy 825 after approximately 6 months of exposure to chloride-containing environments [39].

phase. Molybdenum in Type 316 alloy affocted the composition and growth rate of iron oxides, decreased the dissolution rate of chromium in the transpassive region, and inhibited $\mathrm{Cl}^{-}$in its penetration through the oxjde film. Thercfore, molybdenum played an important role in prolonging the incubation period of SCC. The results showed that molybdenum-bearing Type 316 alloy has better SCC resistance than 321 alloy. The role of molybdenum in SCC resistance was also discussed from the point of view of alloy thermodynarnics. 


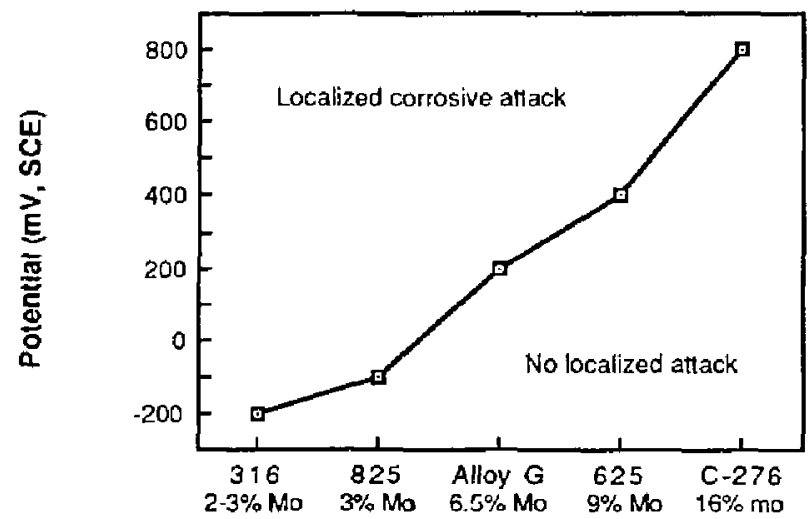

Figure 24. Effect of molybdenum alloy additions on the localized corrosion potential for a constant applied potentia], 2 \%hr exposure in $3.8 \% \mathrm{FeCl}_{3}$ at $70^{\circ} \mathrm{C}$ [40].

\section{Experimental Data on SCC and Other Forms of LC}

\subsection{Tests for SCC}

SCC experiments can be classified into three categories: (i) tests on statically loaded smooth samples; (ii) tests on statically loaded precracked samples; and (iii) tests using slowly strained samples. Tests on statically loaded smooth samples are usually conducted at various fixed stress levels, and the time to failure of the sample in the environment is measured.

Tests on statically loaded precracked samples are usually conducted with either a constant applied load or with a fixed crack opening displacement, and the actual rate or velocity of crack propagation, $d a / d t$, is measured. As a result, $d a / d t$ is plotted vs the stress intensity, $K$.

Much of the data for transgranular stress corrosion cracking (TGSCC) and intergranular stress corrosion cracking (IGSCC) found in the literature was obtained from classic $U$-bend and bent beam experimests $[42,43]$. The stress of principal interest in the U-bend specimen is circumferential. It is nonuriform because (1) there is a stress gradient through the thickness varying from a maximum tension on the outer surface to a maximum compression on the inner surface, (2) the stress varies from zero at the ends of the specimen to a maximum at the center of the bend, and (3) the stress may vary across the width of the bend.
When a U-bend specimen is stressed, the material in the outer fibers of the bend is strained into the plastic portion of the true stress-true strain curve. As discussed in ASTM Standard Procedure G30 [44], the total strain $\varepsilon$ on the outside of the bend can be closely approximated to the equation:

$E=T / 2 R$ when $T \ll R$

where:

$T=$ specimen thickness, and

$R=$ radius of the bend curvature

Stressing is usually achieves by vither a one- or a two-stage operation. Single-stage stressing is accomplished by bending the specimen into shape and maintaining it in that shape without allowing relaxation of the tensile elastic strain. Two-stage stressing involves first forming the approximate U-shape, then allowing the clastic strain to relax completely before the second stage of applying the test stress.

In two-stage $U$-bend experiments such as those conducted by Warren, the applied flexural stress, $\sigma$, is proportional to the deflection, $d$, as shown in Fig. 25 [42]. The deflection, $d$, and applied stress are related by Eq. (24b). 


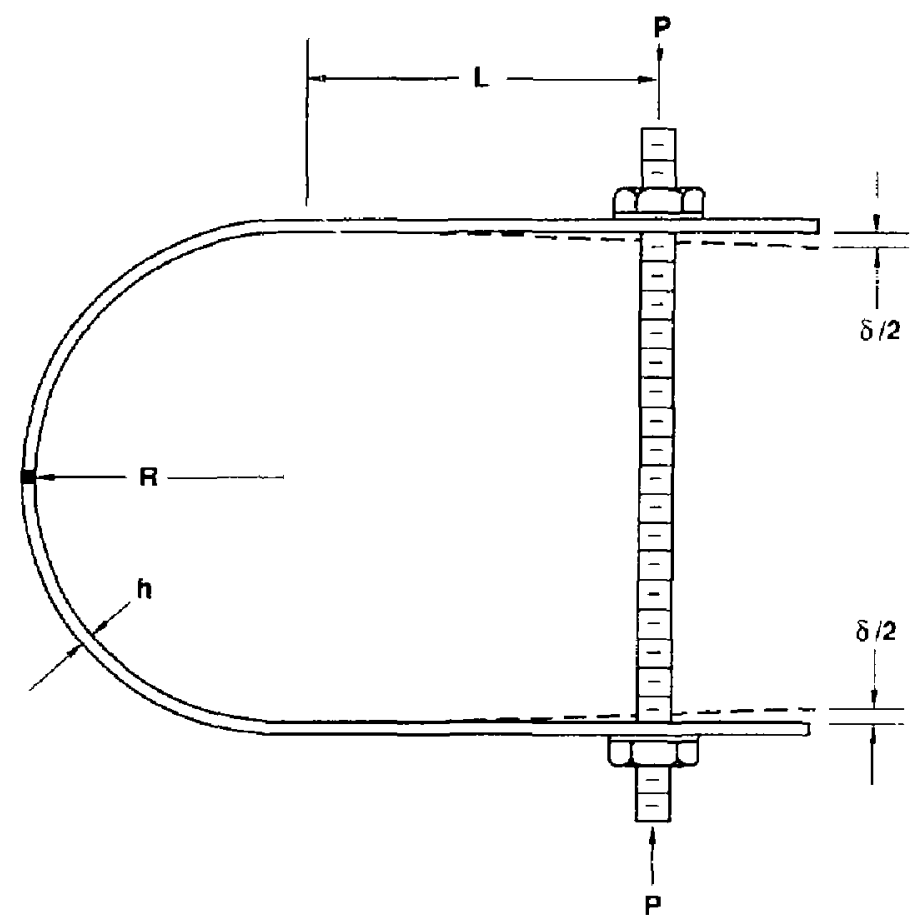

Figure 25. Schematic showing parameters in a U-bend experiment [42].

$d=\{\mid 12 \sigma(2 R+h)] /[(L+R)(B R+h) h E \mid)$

$$
\times\left[L^{3} / 3+R\left(\pi L^{2} / 2+\pi R^{2} / 4+2 L R\right)\right]
$$

where $E$ is the modulus of elasticity, $R$ is the radius of the specimen bend, $h$ is the specimen thickness, and $L$ is the length of the specimen straight section.

Four-point, bent-beam tests are also used to determine susceptibility to SCC [43]. The specimen is supported at the ends and by forcing two inner supports against it in a fashion shown in Fig. 26. The two inner supports are usually located symmetrically around the midpoint between the outer supports. As discussed in ASTM Standard Procedure G39 [45], the elastic stress for the midportion of the specimen (between contact points of the inner support) in the outer fibers of four-point-loaded specimens can be calculated from the following relationship:

$\sigma=12 E t y /\left(3 H^{2}-4 A^{2}\right)$ where:

$\sigma=$ maximum tensile stress,

$E=$ modulus of elasticity,

$t=$ thickness of specimen,

$y=$ maximum deflection (between outer supports),

$H=$ distance between outer supports, and

$A=$ distance between inner and outer supports.

The dimensions are often chosen so that $A=: / 4$.

Either of these techniques can be used to determine a threshold stress, $\sigma_{\mathrm{th}}$. The threshold stress is illustrated in Figs. 27 and 28 and is defined as the stress at which the time to failure approaches infinity $[46,47]$.

More recently, corrosion scientists have begun to use slow strain rate testing (SSRT) in clectrochemical environments [48]. Usually, a tensile machine pulls a smooth sample that is exposed to the corrosive environment at a low crosshead speed $\left(10^{-5}\right.$ to $\left.10^{-9} \mathrm{~m} / \mathrm{s}\right)$. The strain to failure in 


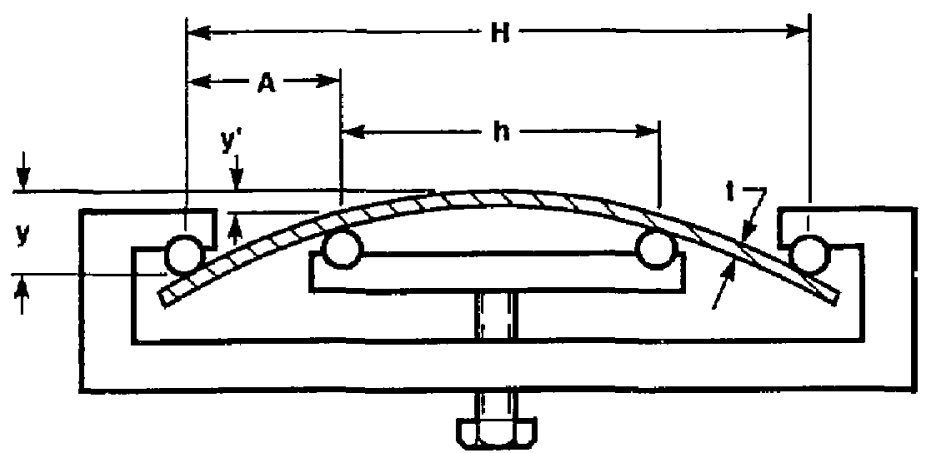

Figure 26. Configuration for a four-point loaded specimen [43].
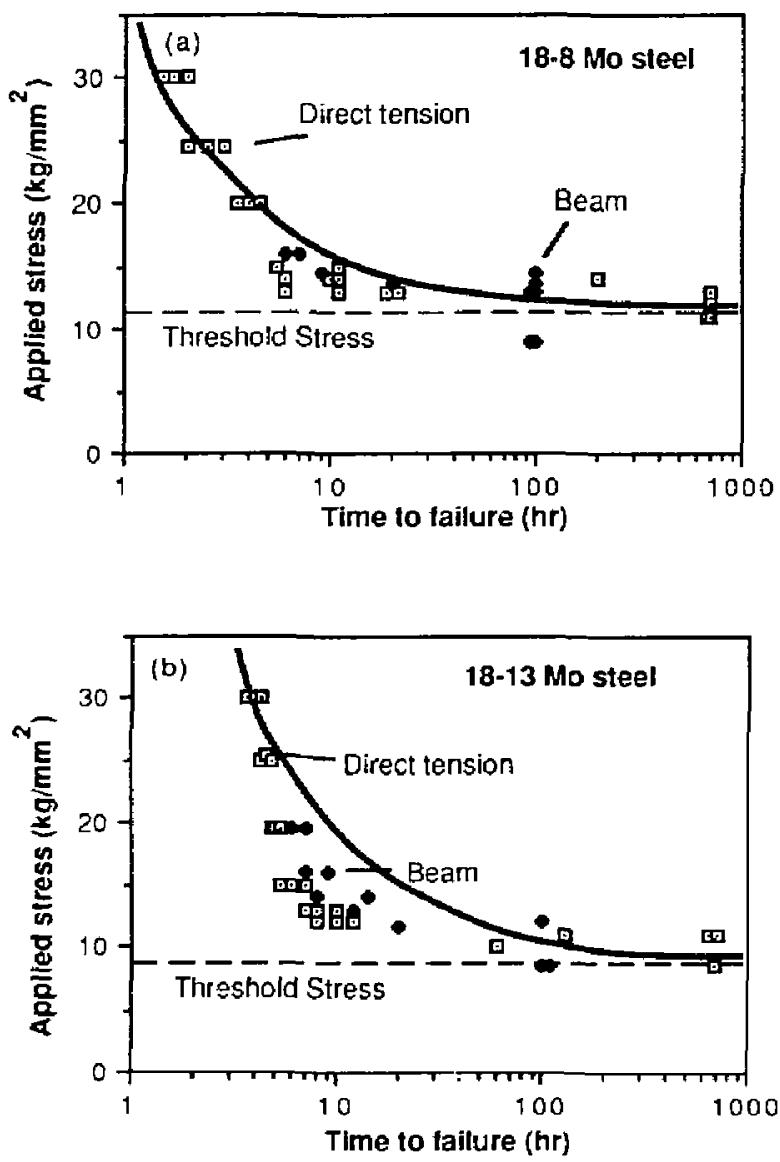

Figure 27. Results of SCC tests on 18-8 and 18-13 molybdenum steels in boiling $\mathrm{MgCl}_{2}$ solution [47]. 


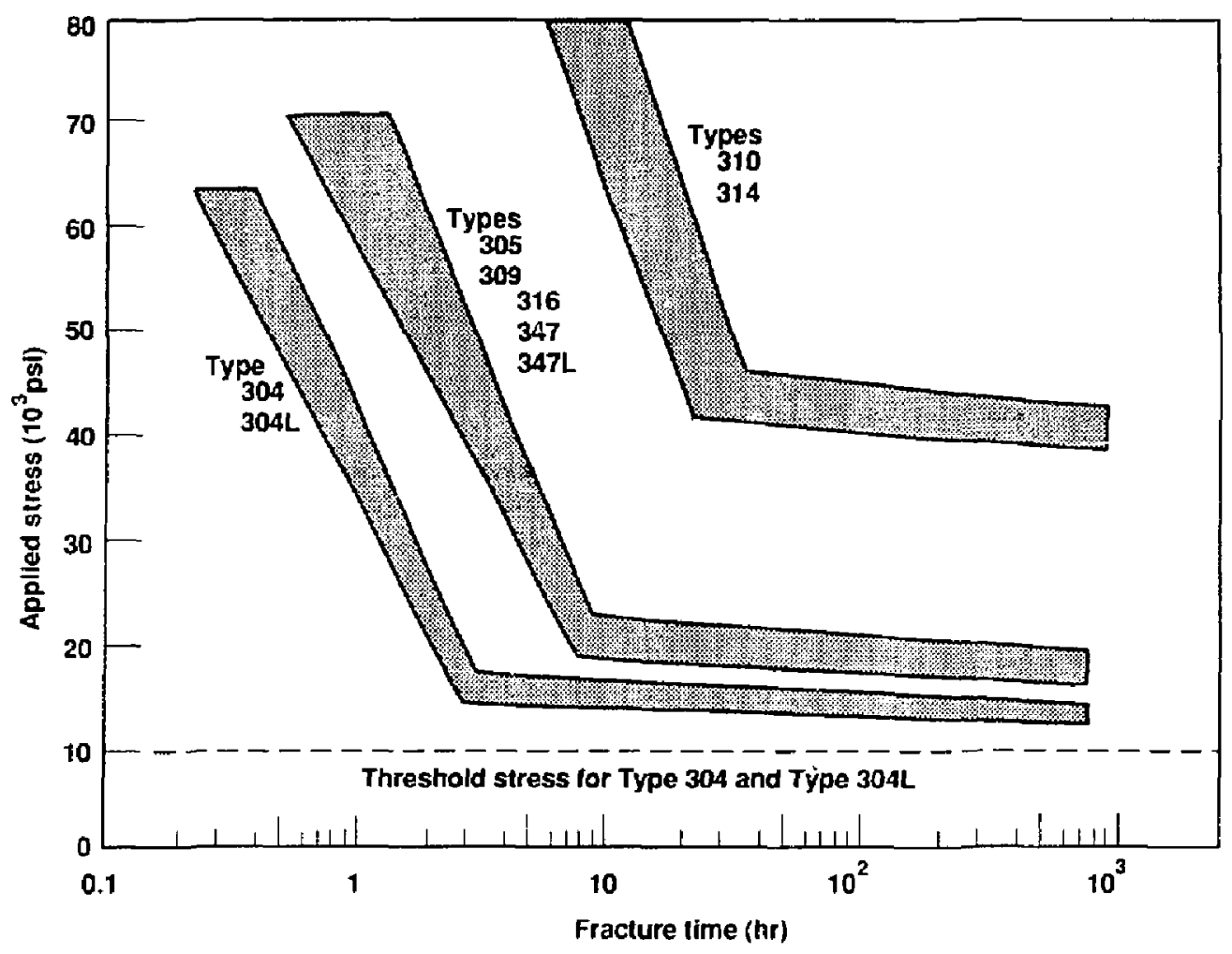

Figure 28. Composite curves illustrating the relative SCC resistance for commercial stainless steels in boiling $42 \% \mathrm{MgCl}_{2}[3]$.

the corrosive environment can then be plotted against the strain rate. In the future, it may be possible to use both acoustic emission and electrochemical noise measurements to better determine model parameters from precise analysis of individual steps in the rupture/tepassivation process [49].

Solomon has used SSRT to study SCC in Type 304 stainless steel in oxygenated $288^{\circ} \mathrm{C}$ water [50]. In this work, Solomon found that the type of cracking was determined by the degree of sensitization (DOS), defined as the percentage of grainboundary attack, and the strain rate, $d \varepsilon / d t$. This is jllustrated in Fig. 29. In the case of unsensitized samples (DOS $<26$ ), ductile failure was observed at values of $d \varepsilon / d t>2 \times 10^{-4} \mathrm{~min}^{-1}$; TGSCC was observed at values of $d \varepsilon / d t<2 \times 10^{-4} \mathrm{~min}^{-1}$. In the case of sensitized samples (DOS > 91), ductile failure was observed at values of $d \varepsilon / d t>6 \times 10^{-3} \mathrm{~min}^{-1}$ : IGSCC was observed at values of $d \varepsilon / d t<6 \times 10^{-3} \mathrm{~min}^{-3}$. At intermediate values of DOS, "granulated" attack was observed.

From Solomon's work, it is clear that when SSRT is used to study SCC phenomena, the experimentalist has to be very careful to sclect a sufficiently slow strain rate, $d \varepsilon / d t$, so that fraclute can occur by corrosion-assisted processes (film rupture and repassivation).

\subsection{Types of Test Environments for SCC}

Type 304 stainless steel in boiling $42 \% \mathrm{MgCl}_{2}$ has become the modei system for SCC studies. In fact, boiling $42 \% \mathrm{MgCl}_{2}$ is specified for SCC tests by ASTM Standard G-36 [19]. $\mathrm{MgCl}_{2}$ solutions are probably the most aggressive SCC agent for 


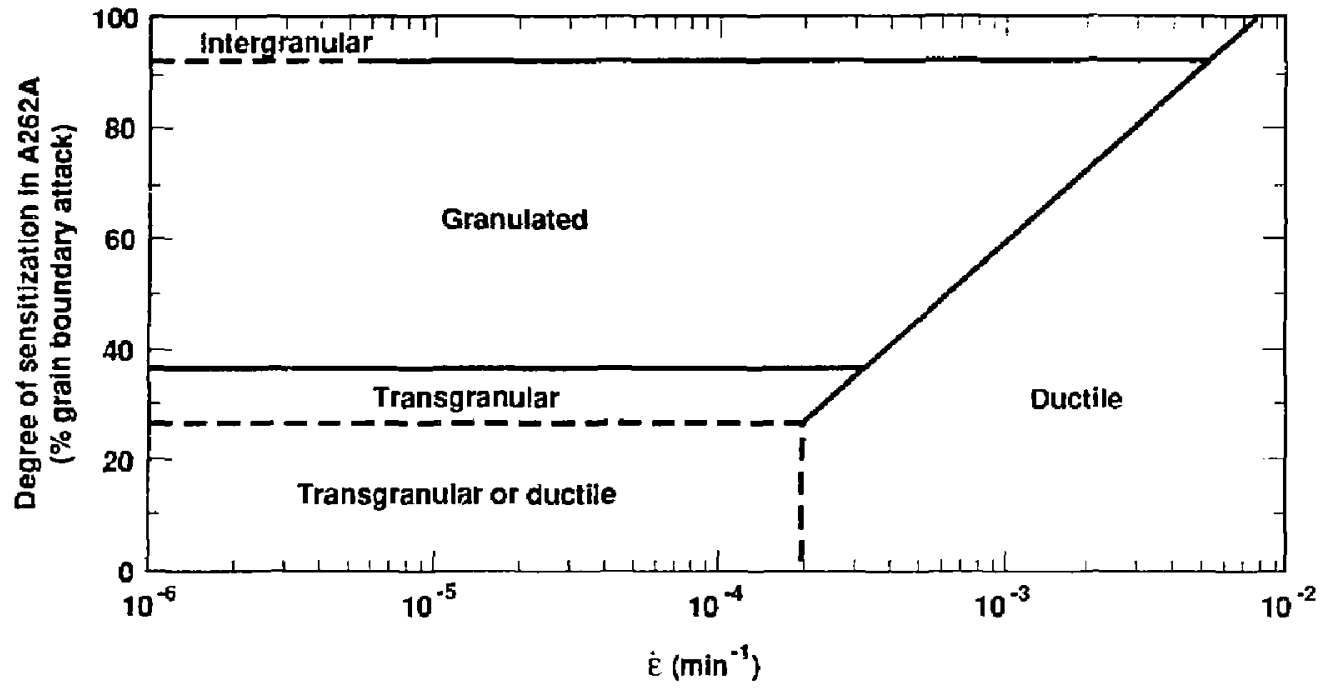

Figure 29. Fracture map showing the mode of fracture as a function of the degree of sensitization of the test specimen and the strain rate employed in the slow strain rate test [50].

the 300 -series staintess sicels. This was demonstrated by Warren 142!. He exposed 18-8 steel U-bend saniples to several chloride solutions, each having a different cation. The cations investigated included $\mathrm{Na}^{+}, \mathrm{Ca}^{2+}, \mathrm{Fe}^{3+}$, and $\mathrm{Mg}^{2+}$; the $\mathrm{Mg}^{2+}$ cation proved to be the most aggressive (Fig. 30). Warren also demonstrated the detrimental effect of $\mathrm{pH}$ suppression on Type 304 stainless steel in $\mathrm{MgCl}_{2}$ solutions (Fig. 31). For this reason, an abundance of literature has been published on SCC studies in $\mathrm{MgCl}_{2}$ solutions. Furthermore, many of these publications have focused on Type 304 stainless stecl because this alloy is of great industrial importance and is rela+ively susceptible to TCSCC in the annealed state and ICSCC in the sensitized state [5]-70].

Harsh-boiling $\mathrm{MgCl}_{2}$ solutions enable the experimentalist to perform screening tests of alloys. However, other test environments are of more practical importance. For example, a 3.5\% $\mathrm{NaCl}$ solution approximases conditions in seawater. Note that many articles have also been published on the SCC of Type 304 stainless steel in chloride and sulfate electrolytes [71-109].

High-temperature, high-pressure water with very low levels of dissolved oxygen (DO) and chloride is encountered in boiling-water reactors (BWRs) [110-122]. These reactors, originally fabricated with Type 304 stainless steel, have water systems that are maintained at $289^{\circ} \mathrm{C}\left(551^{\circ} \mathrm{F}\right)$ and $1040 \mathrm{psi}$. The chloride concentrations are usually a few ppm; the DO is less than 200 ppb (with hydrogenwater chemistry). Note that the $D O$ can be almost $200 \mathrm{ppb}$ without hydrogen-water chemistry [123]. Finally, articles have appeared on the effects of various species, inciuding borates $[124,125]$, misceliancous impurities [126], nitrates and DO [127], organic acids [128], and thiosulfate [129, 130].

\subsection{Effects of the Environment on SCC}

Several environmental parameters are known to influence the rate of crack growth in aqucous solutions. These include, but are not limited to, temperature pressure, solute species, solute concentration and activity, $\mathrm{pH}$, electrochemical potential, solution viscosity, and electrolyte agitation.

Congleton et al. studied the effects of chloride and oxygen concentration on SCC in hightemperature water [131]. SSRTs were performed on Type 316 stainless steel in $265^{\circ} \mathrm{C}$ water containing from 0 to 45 ppm oxygen and from less than 0.1 to $1000 \mathrm{ppm}$ chloride. They founs that time to failure, total elongation, maximum load, and reduction in area were all useful 


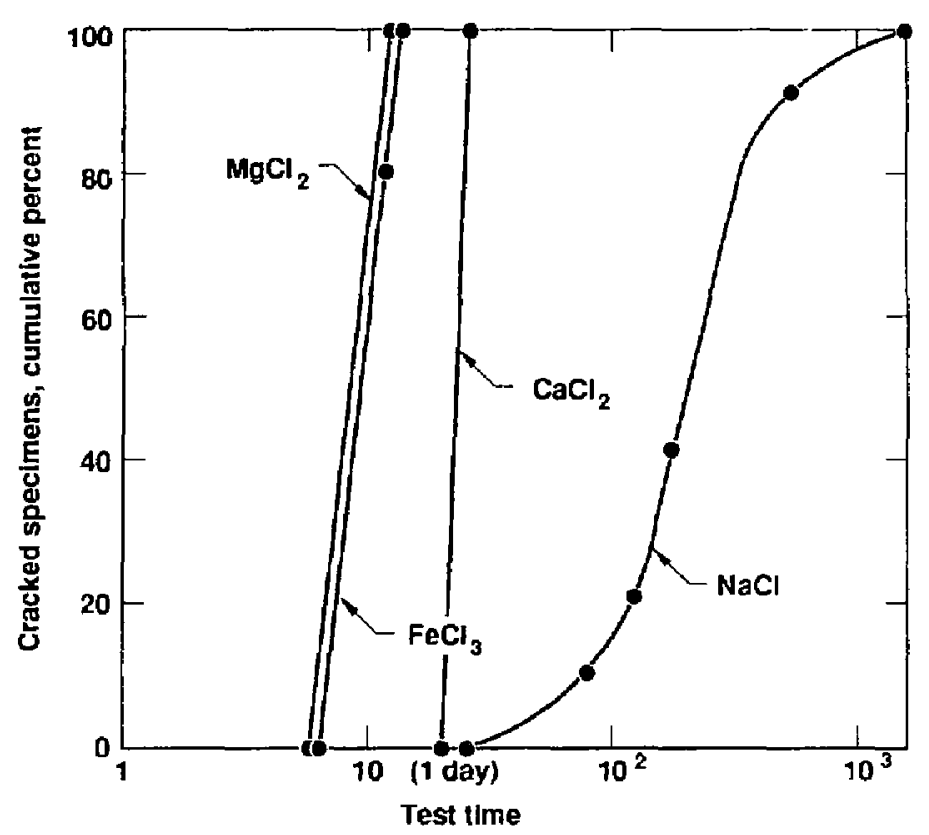

Figure 30. Effect of metallic cation on the time-for-cracking of Type 304 stainless steel specimens exposed at $100^{\circ} \mathrm{C}$ to water containing $100 \mathrm{ppm}$ chloride. $\mathrm{Mg}^{2+}$ is the most aggressive cation [42].

numerical paramecers for quantifying cracking propensity, but they all tended to be less sensitive than metallographic and fractographic examination for identifying small changes in susceptibility or for highlighting differences in the mechanism of cracking. Consequently, metallographic and fractographic studies were extensively used in their present work, and the results were primarily discussed in those terms.

Specimens used by Congleton et al. were fabricated from 4.76-mm-diam rods, had threaded ends and a 2.54 -mm-diam $\times 12.7-\mathrm{mm}$-long gauge length, and were strained in moderately stiff machines, mos! frequently at an initial strain rate of $2 \times 10^{-6} \mathrm{~s}^{-1}$. For each experiment, the time to failure, percentage elongation, and percent reduction in area were recorded. In addition, one-half of the fractured specimen was sectioned at midplane through the longest observable surface crack and prepared for metallographic examination, the remaiting part being exar ined by scanning electron microscopy where considered necessary. All potentials were measured relative to the $\mathrm{Ag}-\mathrm{AgCl}$ external reference electrode.

Tests were performed on both anncaled and sensitized Type 316 stainless steel. For the specimens sectioned at midplane, the maximum crack lengths in the necked region, $a_{\mathrm{n}}$ and in the uniformly deformed gauge length, $a_{5}$, werc medsured. An examination of the number and distribution of cracks in the section indicated three somewhat different types of cracking. Type A denotes the situation in which the cracks had similar lengths in both the necked and unnecked regions, implying that the crack growth rate is relatively independent of stress level (once the threshold is exceeded) and that crack initiation occurred well before the onset of necking. In contrast, Type B refers to a case in which cracks in the necked region were somewhat longer than in the uniformly deformed gauge length. This difference is due to the dependence of crack propagation rate on stress intensity. Finally, Type $C$ refers to a case in which cracking occurred almost exclusively in the necked region at stresses well 


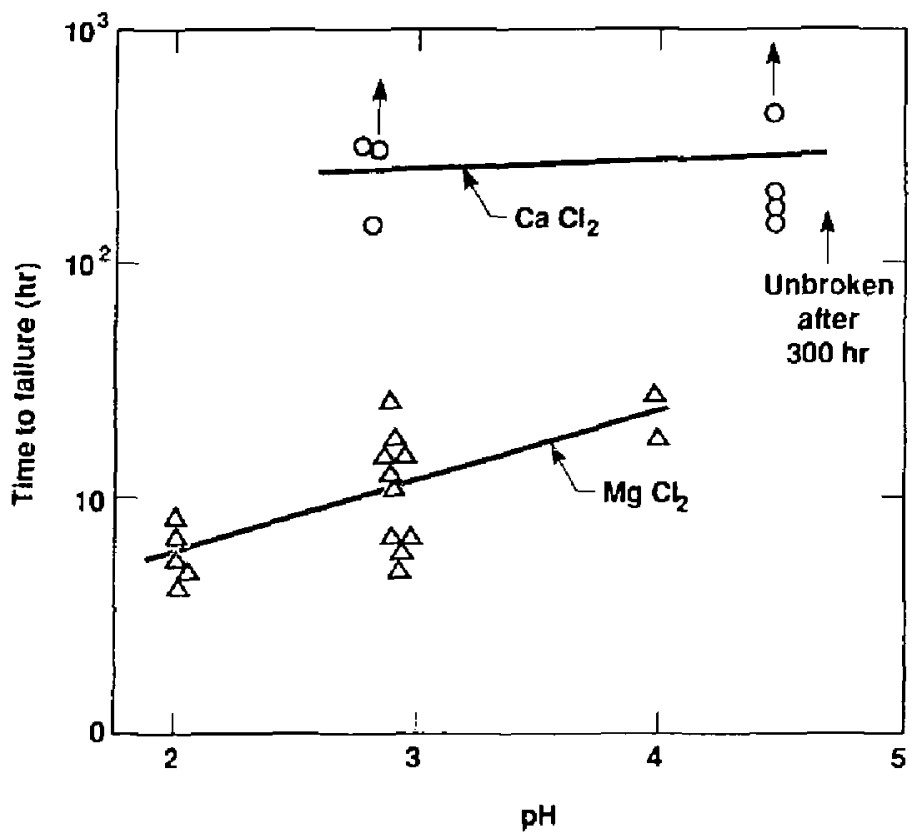

Figure 31. Effect of $\mathrm{pH}$ on the time to failure of Type 304 stainless steel at 50,000 psi in $\mathrm{MgCl}_{2}$ and $\mathrm{CaCl}_{2}$ solutions at $125^{\circ} \mathrm{C}$ [42].

above the yield stress (YS) and approaching the ultimate tensile stress (UTS).

One parameter that can be useful in assessing susceptibility to SCC from SSRTs is the crack growith ratc, although there are various ways in which this can be calculated. An average crack growth rate can be obtained by dividing the maximum length by the total test time. This average crack growth tate can conveniently separate susceptibie material from unsusceptible material but takes no account of differences in the time for crack initiation that occur from specimen to specimen.

There are thus three methods that can be used for obtaining a crack growth rate: (i) $V_{\mathrm{m}}=a_{\mathrm{rnax}} /$ (total tjme); (ii) $V_{L}=a_{s} /($ time to maximum load); and (iii) $V_{\mathrm{H}}=\left(a_{\mathrm{t} 1}-a_{\mathrm{s}}\right) /($ total time - time to maximum load). Clearly, $V_{m}$ neglects any initiation time and is likely to be more applicable to Types $A$ and $B$ cracking, which also are relevant to $V_{L}$, where crack initiation and growth occur at low stresses. On the other hand, $Y_{11}$ appears to be most selevant for cracks that initiate and grow at high stresses, as with Type C cracking. The differences between $V_{L}$ and $V_{m}$ are small, whereas $V_{I I}$ is usually the largest, presumably because of an increase in velocity as $K_{\text {ISCC }}$ is approached. The velocities $V_{m}$ or $V_{L}$ are probably the mote realistic for practical considerations, and $V_{11}$ is only likely to be relevant in the later stages of a failure, where stress intensification is high and total failure imminent.

The available data have been plotted using an interpolation ptocedure. $V_{m}$ is described as a function of oxygen and chloride contents for the annealed condition (Fig. 32) and for the sensitized state (Fig. 33). In the case of annealed material, maximum crack velocities were observed at high and low oxygen or chloride concentrations. In contrast, the sensitized material shows high crack velocities extending from intermediate oxygen contents and very low chloride levels to wider oxygen limits as the chloride increases. The implication would appear to be that in components that contain regions of sensitization bul are otherwise in the annealed state, cracking may 


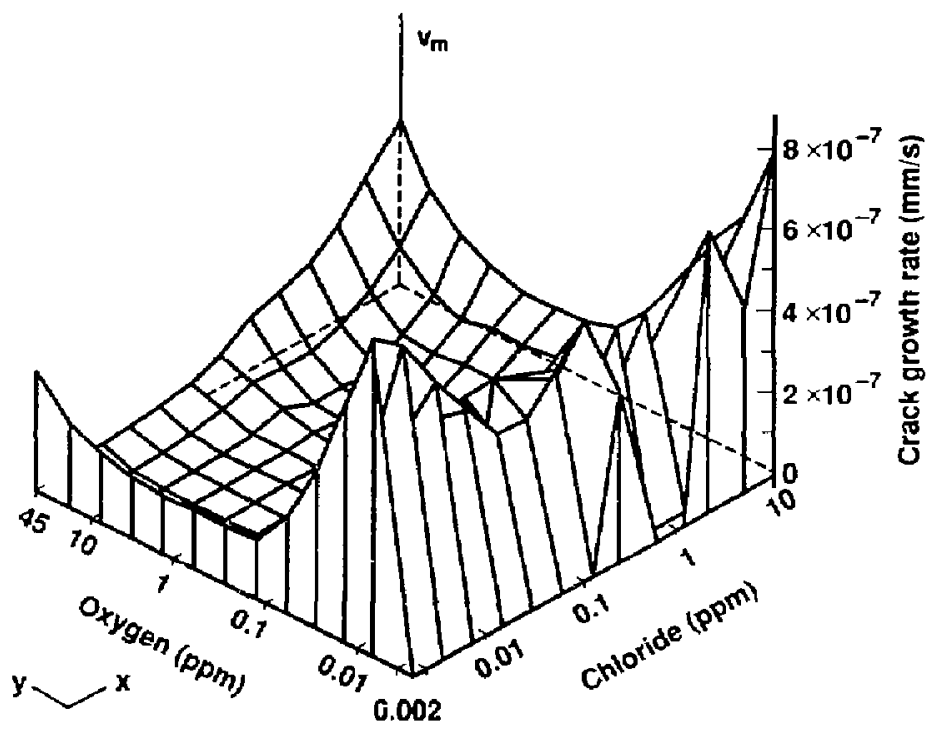

Figure 32. The effects of oxygen and chloride contents of waters on mean crack growth rates in annealed Type 316 stainless steel [131].

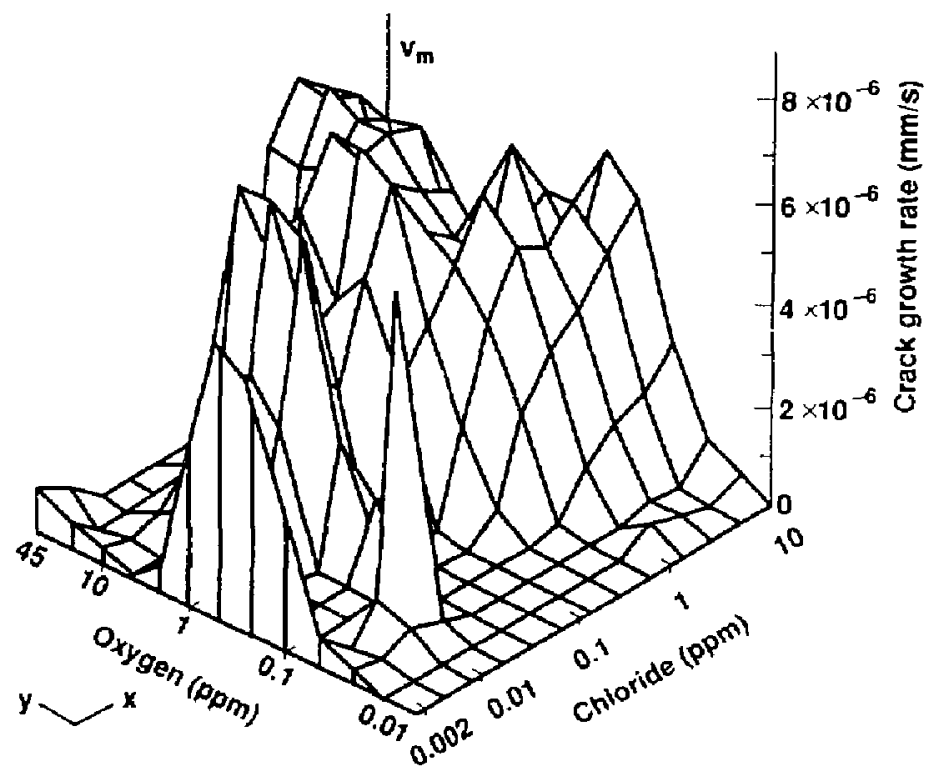

Figure 33. The effects of oxygen and chloride contents of waters on mean crack growth rates in sensinized Type 316 stainless steet [131]. 
occur over virtually the whole range of oxygen and chloride contents studied.

Figure 34 shows plots of $V_{L}$ and $V_{H}$ against chloride content for the annealed steel and reinforces the point that any definition of susceptibility to SCC should take stress into account.

Figure 35(a) shows the mean crack growth rale for annealed stainless steel plotted against potential inferred from the appropriale water conditions, using the potential map given in Fig. 35(b). It is clear that a no-cracking regime exists for anncaled material in the potential range from about -200 ko $+150 \mathrm{mV}$. SHE. Such data clearly contirm the two potential ranges in which cracking occurs for annealed material. Above about $150 \mathrm{mV}$, SHE, isolated cracks form and grow to relatively large depihs, whercas at low potentials, a multitude of short cracks form close to one another, and these readily link together to give a shallow anmulus of transgranular cracking.

The review by Gordon of the susceptibility of Type 304 stainless steds in oxygenated and chlorinated high-temperature waters used the data of Williams, as well as those of many other ineestigators, to obtain a revised diagram showing the domains of water composition within which cracking occurred $[132,133 \mid$. Williams original data are shown in Fig. 36, and Congleton's data are shown in Figs. 37 and 38 . F rares 39 and 40 show the results of experiments by Congleton ct al. together with those produced by earlier workers in the form of the plots used by Gordon. The upper line in Fig. 39, due to Williams, indicates that transgranular cracking only occurs in annealed stainless steels for the high-chloride and high-oxygen region of the diagram.

The following conclusions are drawn from the work of Congleton et al. First, the predominant cracking modes for anncaled and sensitized Type 316 stainless stecl in high-lemperature waters are transgranular and intergranular, respectively. In very-low-nxygen waters containing $210 \mathrm{ppm}$ chloride, sensitized material displayed transgranular cracking. The extent of the cracking depended upon the water composition, the severity of the cracking generally increasing with increasing oxygen and chloride contents of the water. Crack growth rates at low or high stresses are functions of oxygen content in particular, but also of chloride content of the waters to some extent. For annealed material, the highest crack growth rates coccurred at low oxygen contents, but for sensitized material, intermediate axygen contents, between 0.1 and $10 \mathrm{ppm}$, gave the highest crack velocitics.

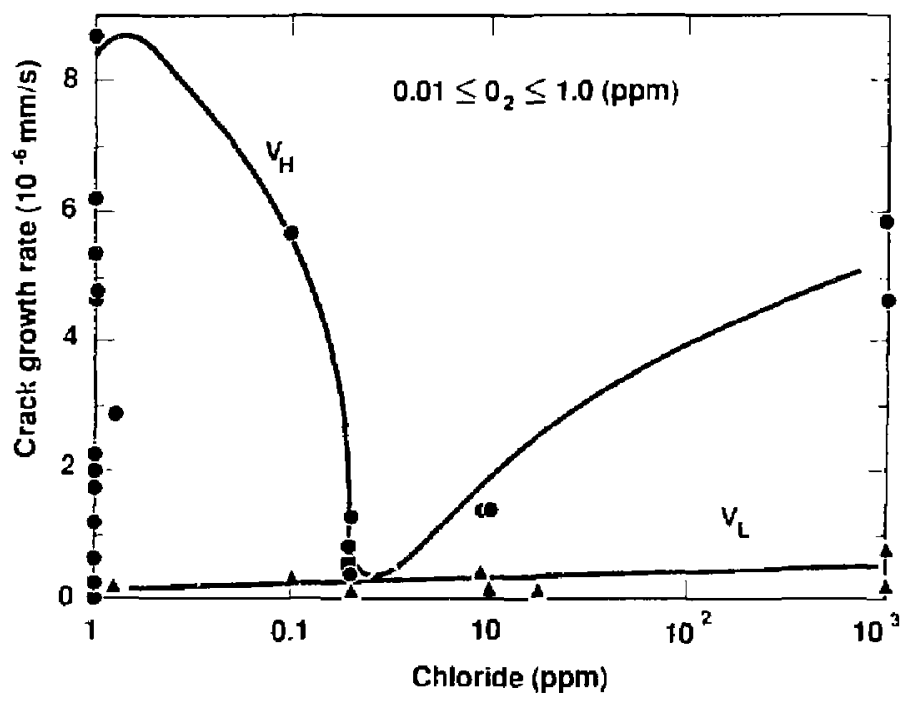

Figure 34. Crack growth rates, $V_{\mathrm{L}}$ and $V_{\mathrm{H}}$, for annealed Type 316 stainless steel as a function of chloride contents of waters [131]. 

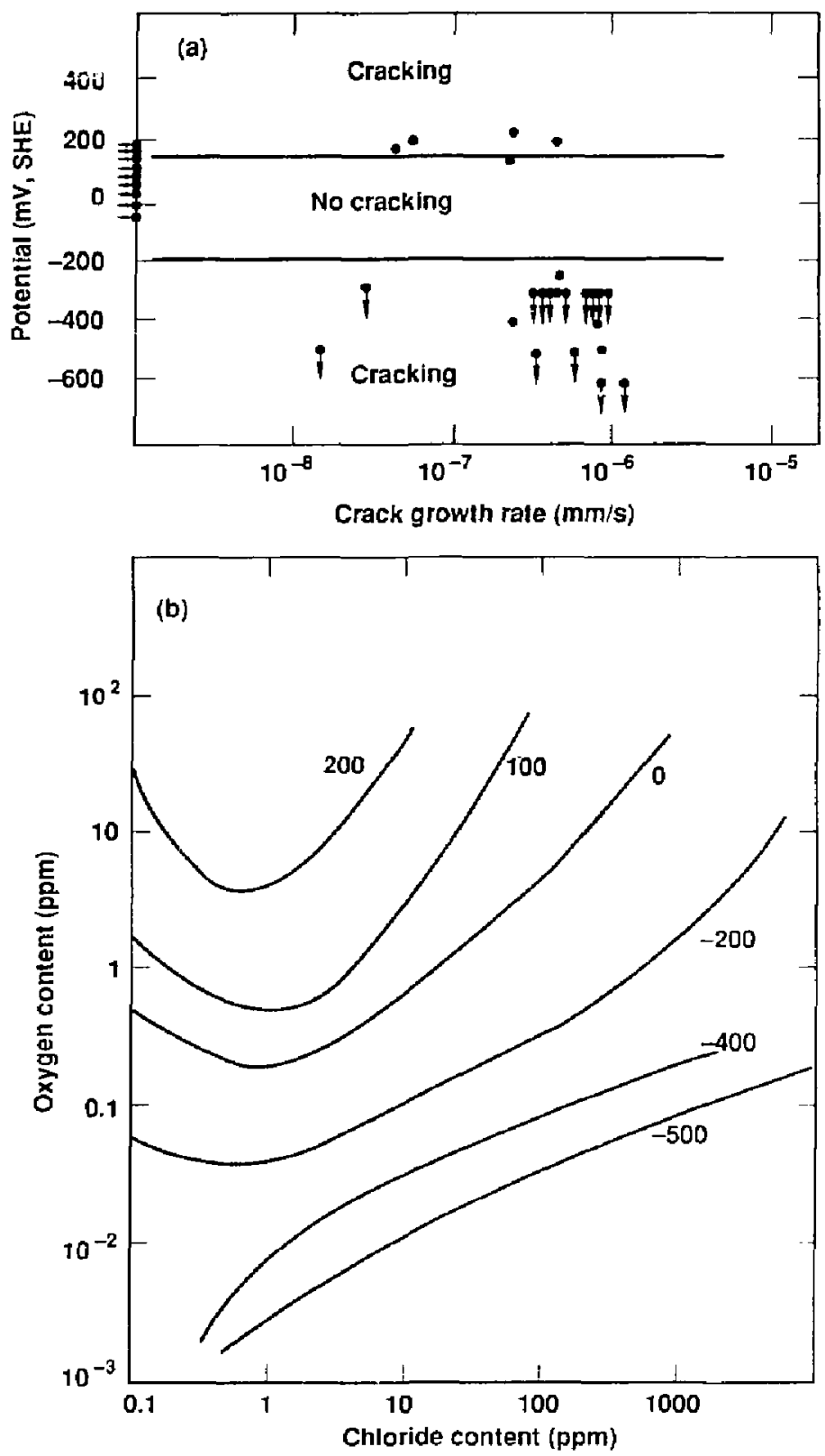

Figure 35. (a) Graph of mean crack growth rate for annealed stainless steel plotted against potential inferred from the annrnpriate water conditions using the potential map given in (b). (b) Potential-oxygen-chloride content map for Type 316 stainless steel in $265^{\circ} \mathrm{C}$ water. Equipotential lines are plotted, the numbers associated with each line indicating the equilibrium potential achieved under those water conditions expressed as mV, SHE [131]. 


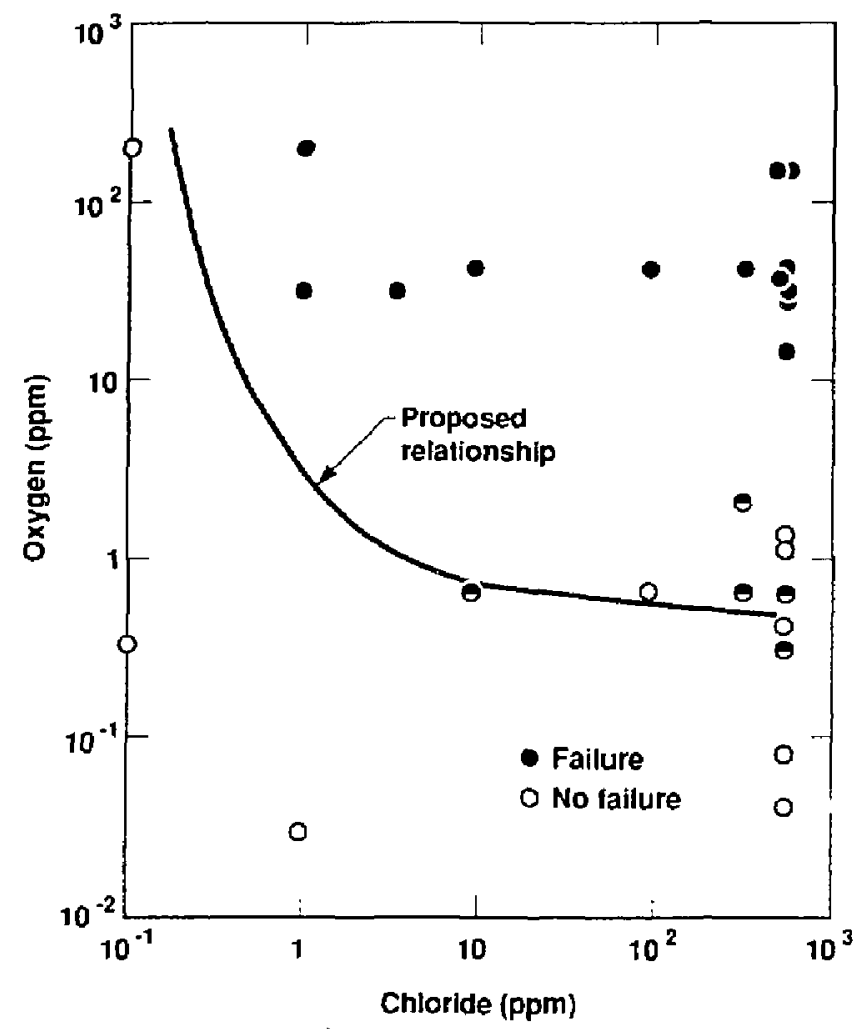

Figure 36. Proposed relationship between chloride and oxygen content of alkaline-phosphate-treated boiler water, and susceptibility to SCC of austenitic stainless steel exposed to the stearn phase with intermittent wetting [133].

The data presented by Congleton et al. significantly affect the positions of the "crackingno-cracking" domains on the $\mathrm{O}_{2}$-Cl diagram by reducing the size of the "no-cracking" domain below that previously absumed. This change is due to the occurrence of transgranular cracking in annealed Type 316 steel at very low oxygen contents even when the chloride is less than $0.1 \mathrm{ppm}$.

Potential-oxygen-chloride maps for annealed Type 316 steel have been obtained that allow the effects of oxygen and chloride contents of walers upon the incidence of cracking to be explained in terms of potential. By appropriate potentiostatic control, cracking may be prevented in waters that promote cracking at open circuit polential, or it may be promoted in waters that prevent cracking at the free corrosion potential. The reasons for the dependence of cracking on potential, and hence water composition, in Type 316 stainless steel will remain obscure until more electrorhemical and other data , re available.

\subsection{Effects of Alloy Composition on SCC}

First, the gencral effects of alloy composition (nickel content) are considered. The most wellknown curve summarizing the data for the effect of nickel on the chlonide $\mathrm{SCC}$ of $\mathrm{Fe}-18 \mathrm{Cr}$ alloys is that shown in Fig. 41. as originally reported by Copson [134] and discussed by wu [135]. 


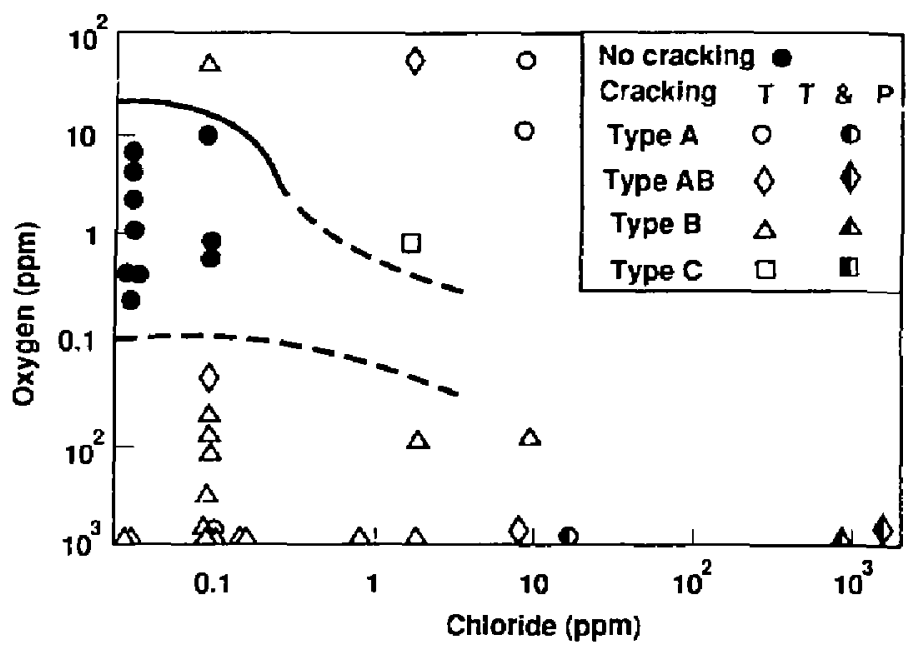

Figure 37. Types of SCC observed in annealed Type 316 stainless stee] as a function of oxygen and chloride contents of waters [131]. $T$, transgranular; P, pitting. Type $A, a_{n} / a_{s}=1$; Type B, $a_{n} / a_{9} \geq 2$; Type $C, a_{s}=0$; where $a_{n}$ is the crack length in the necked region, and $a_{s}$ is the crack length over the uniform gauge length.

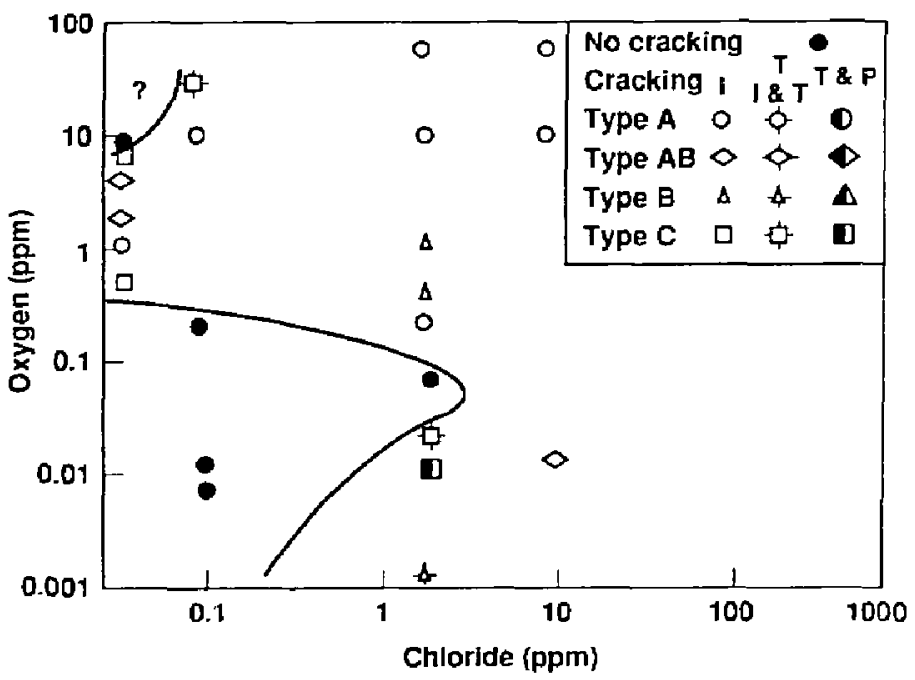

Figure 38. Types of SCC observed in sensitized Type 316 stainless steel as a function of oxygen and chloride contents of waters [131]. I, intergranular; T, transgranu]ar; P, pitting. (See Fig. 37 for meanings of A, B, and C.) 


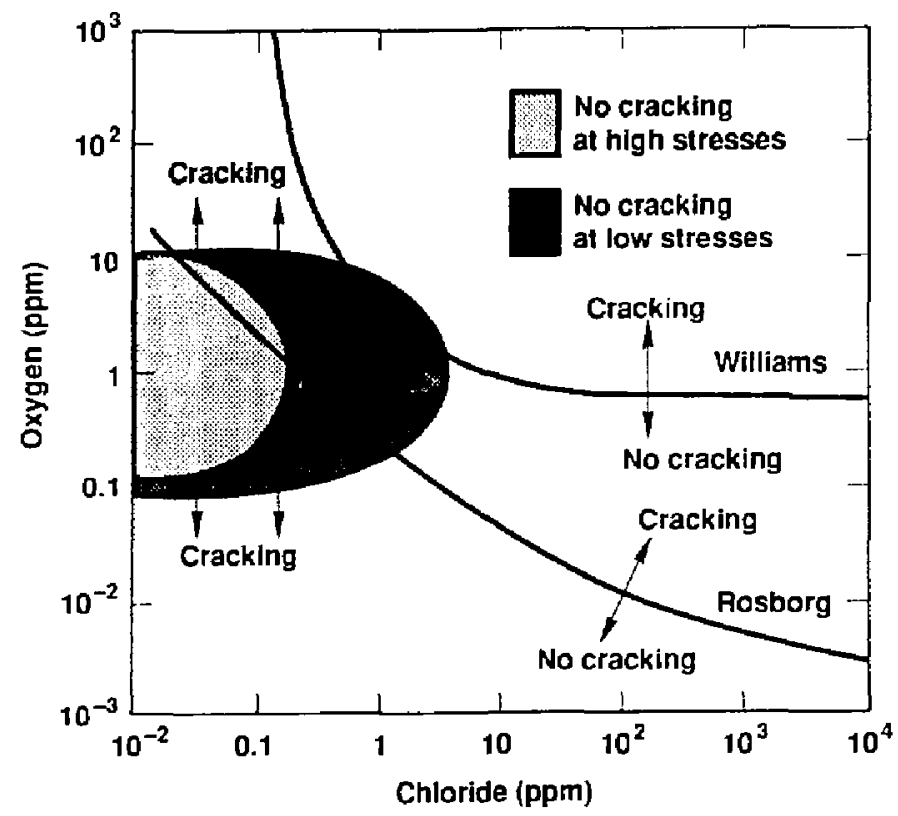

Figure 39. Cracking and no-cracking regimes for annealed Type 316 stainless steel as a function of oxygen and chloride contents of waters [131].

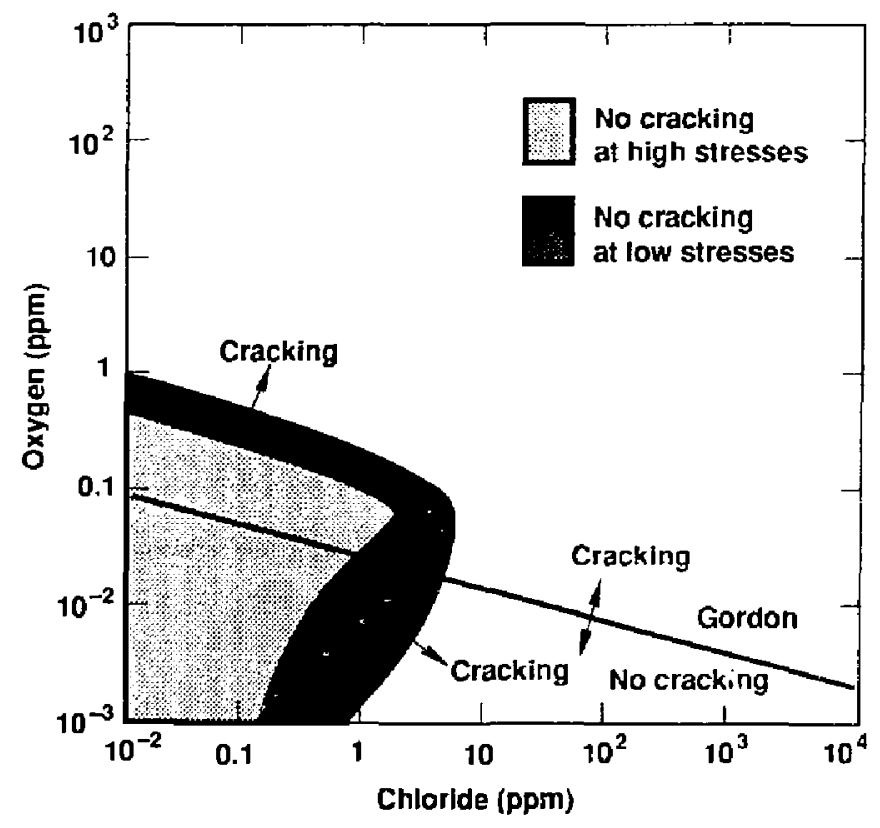

Figure 40. Gacking and no-cracking regimes for sensitized Type 316 stainless steel as a function of oxygen and chloride contents of waters [131]. 


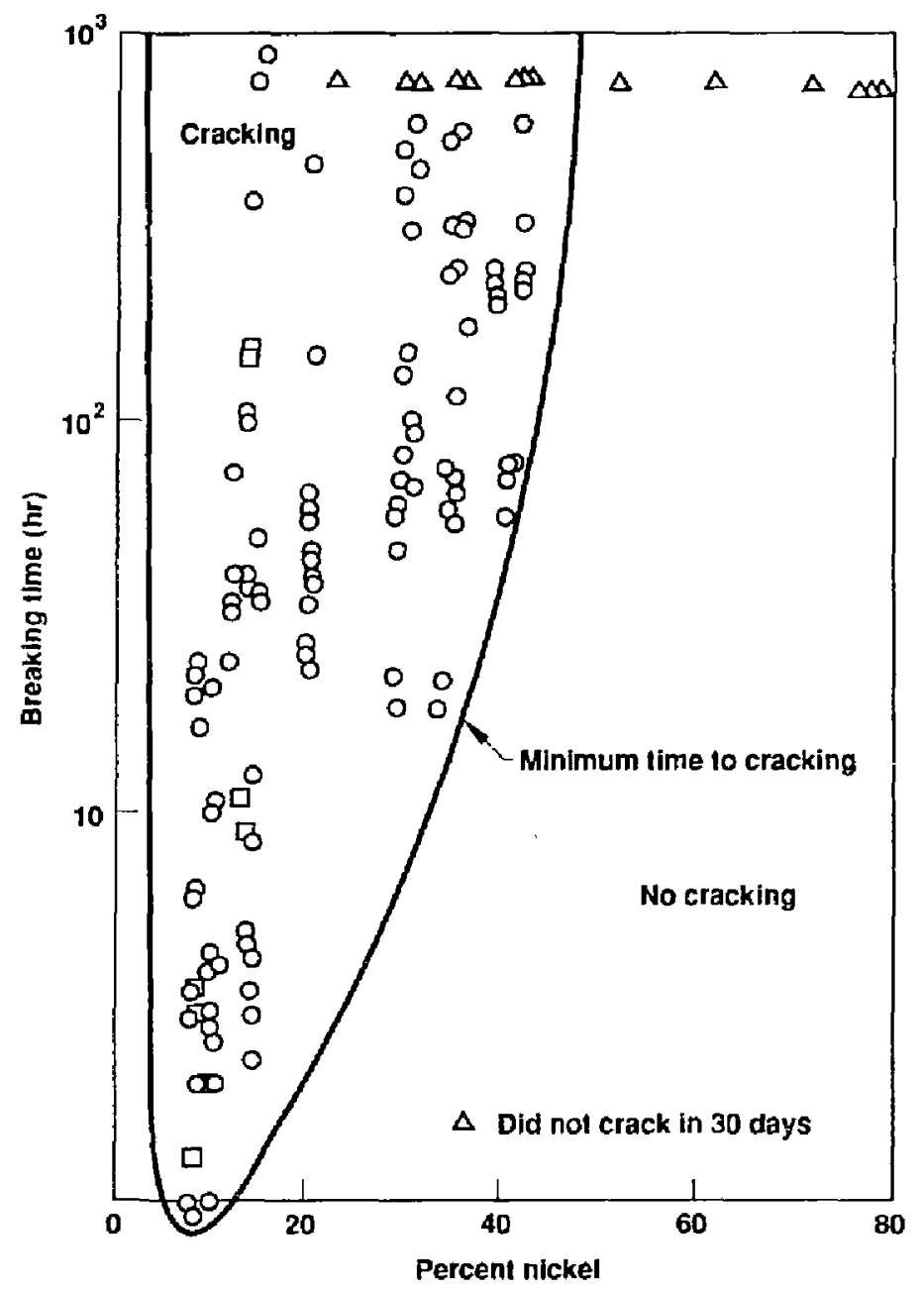

Figure 41. Effect of increasing the nickel content on the susceptibility of iron-chromium-nickel wires in boiling $42 \% \mathrm{MgCl}_{2}[134]$.

On the basis of the results shown in the rigure, it is reasonable to conclude that alloys with more than 45 to $50 \%$ nickel should be resistant to chloride cracking. In the case of $12 \%$ chromium martensitic steels, the cracking resistance in a chloride environment is dependent upon the final tempering temperature [136]. For example, Type 410 stainless steel tempered at approximately $565^{\circ} \mathrm{C}$ and above is resistant to cracking in chlo. rides, and when tempered in the region of $455^{\circ} \mathrm{C}$ it is very susceptible to cracking in chlorides.
However, this could be due to the structural changes brought about by tempering. The sceond conclusion, that higher-nickel alloys are immune to cracking in chlorides, should be modified, because high-nickel alloys such as Alloy 600 (Inconel) have been reported to crack, even in high-purity water [137]. Stachle reporied that Alloy 718 (Inconel), which contains 50-55\% nickel, is still susceptible to cracking in chlorides [138]. This may be due to the precipitation of a gamma double-prime phase, $\mathrm{Ni}_{3}(\mathrm{Al}, \mathrm{Ti})$, which 
leads to reduction of the nickel content of the alloy matrix.

Kowaka et al. conducted studies to develop a SCC-resistant stainless steel as one of the countermeasures against SCC in the piping systems of BWRs [139]. It was found that molybdenum in Type 316 stainless sted has the bencficial effect of increasing $\$ C C$ resistance by rctardation of chromium carbide precipitation at grain boundaries, thereby reducing the tendency toward sensitization. Kowaka et al. believe that molybdenum also promotes the formation of a molybdenum-containing passive film, which is also rich in chromium.

Duckworthet al. performed clectrochemical folarization and exposure tests and found that the piting/erevice corrosion of chemical-plant materials is related to the water content of the hydrochloride solt |140). Corrosion resistance of Alloys C-276 and 825 is superior to that of Type 316 stainless sted because of increasing amounts of chromium and molybdenum. Kyrolainen [141], Carter et al. |142], Fujii [143|, and Maiya [144] have also obsened that increased molybdenum confent enhances resistance to localized corrosion of 300-series austenitic stainless stcels.

Oltra and Colson studied the effect of chromium, nickel, and molybdenum additions on the SCC of austenitic stainless steels in chioride solutions $[145]$. Using the constant strain rate (CSR) method, various criteria allowed evaluation of these compositional effects on mechanical depassivation, localized dissolution, and repassivation. The investigation was conducted in boiling $47 \% \mathrm{MgCl}_{2}$ solution. This study found that nickel decreases the eritical elongation sate required for localized depassivation. The density of cracks formed at a given elongation rate was decreased by the adjition of molybdenum. Chromium increased the density of crack initiation.

\subsection{Carbon Content and Sensitization}

ICSCC of austenitic stainless stcels occurs when these materials are subjected to a sufficiently severe combination of stress, cortosive environment, and sensitization, a term denoting increased susceptibility to attack following a thermal exposure that cauers chromium-rich $\mathrm{M}_{23} \mathrm{C}_{6}$ carbides $\mathrm{to}$ precipilate at grain boundaries.

The phenomenun of sensitization has been the subject of extensive investigation [146-171]. Chromium carbide precipitation in stainless stecls occurs in the temperature range from 500 to $850^{\circ} \mathrm{C}$ $\left(930\right.$ to $1560^{\circ} \mathrm{F}$ ), with the rate of precipitation controlled by chromium diffusion [24]. A variety of metallurgicai changes have been suggested as mechanisms for sensitization, but it is generally accepted that the principal feature responsible is a narrow chromium-clepleled zone adjacent to the carbides. This merhanism was suggested in 1933 by Bain et al. [146] and was further developed by Stawstrom and Hilkert|147] and Tedmon et al. [148]. Tedmon ct al. suggest that susceptibility to intergranular attack uccurs when there is an essentially continuous zone in which the local chromium concentration is below about 13 at.\%. Chromium is the colement responsible for the formation of stable passive films in stainless stecls, and localized depletion of this element adjacent to grain boundaries results in the establishment of an active path fone which deres not repassivate) into !he bulk material.

The austenite chrorrium concentration in equilibrium with the $\mathrm{Cr}_{23} \mathrm{C}_{6}$ carbide depends most sensitively on the activity coefficient of chromium and on the activity of carbon, as expected from thermerdyamic arguments. It is assumed that the diflusing chromium atom reacts with a coordinated carbon atom, which is represented by $(6 / 23) \mathrm{C}$

$\mathrm{Cr}+(6 / 23) \mathrm{C} \leftrightarrow \mathrm{CrC}_{6,2} ;$

The equilibrium constant for this reaction, $K_{\mathrm{CrC}}$, is related to the standard free energy of formation for this rezction, $\Delta \mathrm{G}_{\mathrm{CrC}}^{\circ}$ by Eq. (27).

$\left.K_{\mathrm{CrC}}=\exp \left(-\Delta \bar{G}_{\mathrm{CrC}}^{2}\right) / R T\right)$

where $R$ is the universal gas constant and $T$ is the absoilute temperature. The equilibrium constant can also be written in terms of the activities of the two reactants, $a_{C_{r}}$ and $a_{C}$.

$K_{\mathrm{CrC}}=1 /\left[a_{\mathrm{Cr}} \cdot\left(a_{\mathrm{C}_{\mathrm{C}}}\right)^{k_{\mathrm{r}} / 23}\right\}$

From Eq. (28), an expression can be derived for the mole fraction of chromium in the depleted region adjacent to the carbide precipitates, $X_{\mathrm{Cr}_{\text {r.mq }}}$ :

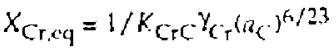

This expression clearly shows that by decreasing the activity of carbon, $a_{C}$, in the bulk alloy, the mole fraction of chromium in the depleted region is increased, thereby decreasing the tendency of an afloy to undergo sensitization. Of course, this 
is why Type $304 \mathrm{~L}$ is less prone to sensitization than Type 304.

In addition to lowering the carbon content of an austenitic alloy such as Type 304 or 336 , it is also possible to add stabilizing elements (strong carbide formers such as titanium and niobium?. Note that the above development is an idealization which neglects the possible formation of carbides from iron, nickel, or stabilizing elements. A thermodynamic model has been developed thy Fullman that accounts for these effects through the incorporation of chromium equivalency parameters, E, 1749]. Sufficient parameters have been included in Fullman's compulational model to predict the effects of aluminum, cribalt. cepper, manganese, silicon, titanium, vanadium, and tungsten on sensitization. The parameter $\varepsilon_{j}$ is defined as the change in chromium content with respect to a change in element $j,-\left(\partial \Gamma_{\mathrm{Cr}} / \partial P_{j}\right)_{X_{\mathrm{C}} \text {. }}$.

Takaku et al. have used constant extension rate lests (CERTs), constant load tests, and cyclic tension tests to study the susceptibility to ICSCC of high-nitrogen, forged stainless steel pipe in $288^{\circ} \mathrm{C}$ water $[150]$. Specifically, this study investigated Types 304LN and 316LN stainless stecls as alternate materials for BWRs. In general, grain refining is relatively difficult in the processing of forged seamless pipe compared with extruded and rolled pipe, in which a high working ratio can be obtained. Therefore, the decrease in strength duc to coarse grainr and low carbon content was compensated for by the solid solution strengthening afforded by the addition of nitrogen. As a result, good ductility and toughness as well as strength were obtained by the addition of 0.10 to $0.133 \%$ nitrogen, for the forged Types 304LN and $316 \mathrm{LN}$ steels.

Takaku et al. also studied low-temperature sensitization and determined that nitrogen addition up to approximatey $0.14 \%$ was not detri. mental to intergranular corrosion resistance. Sensitization could not be induced, provided the carbon content was maintained below $0 .(12 \%$. This study concluded that Types 316LN and 304LN stainless steel pipes, containing approximately $0.14^{\text {\% }}$ nitrogen (maximum), have excellent overall properties, including high SCC resistance in $288^{\circ} \mathrm{C}$ watcr, and are suitable for application in BWRs.

The stress corrosion susceptibility and crack growth rate of austenitic stainless stecl can be described by the degree of sensitization (DOS) as measured by cortosion tests such as the Strauss of electrochemical potentiokinetic reactivation (EPR) tests |151-153]. EPR was developed by the nuclear power industry for determining degree of sensitization in Types 304, 304L, 316, and 316L austenitic stainless steels. The method is nondestructive and was developed to permit the degree of sensitization to be related to susceptibility to ICSCC in high-purity water environments.

The report by Arev and Lvle [152] describes a test program conducted to evaluate the EPR Iest as a method for use in chemical plants to determine whether installed austenitic stainless sted components are sensilized. Results from E[R tersts on Tyoses 304 and 316 stainless sted samples were compared with results from standard ASTM tests. It was concluded that the EPR test is equivalent to the standard electrolytic oxalic acid etch (EOAE) test (ASTM A 262-81, Practice A) for determining whether a component is or is not sensitized. However, the EPR test provides a quantitative measure of the degree of sensitization of stainless steds, which the EOAE iest does not. in this regard, it is to be noted that ASTM Committee $G 1$ is in the process of standardizing the EPR test.

Majidi and Streicher have compared three different electrochemical reactivation tests with etch structures produced in the EOAE test [151]. These nondestructive tests are needed to evaluate welded stainless steel (Types $304,304 \mathrm{~L}$ ) pipes and other plant equipment for susceptibility to intergranular attack. Sensitization associated with precipitates of chromium carbides at grain boundaries can make these materials subject to intergranular attack in acids and, in particular, to ICSCC in high-temperature water $\left(289^{\circ} \mathrm{C}\right)$ in boiling-water nuclear reactor power plants.

In the first of the two older reactivation tests investigated by Majidi and Streicher [151], sensitization is detected by the electrical charge generated during reactivation. In the second, sensitization is measured by the ratio of maximum currents generated by a prior anodic loop and the reactivation loop. A third, simpler reactivation method based on a measurement of the maximum current generated during rcactivation is proposed. If the objective of the ficld tests, which are to the carried out with portable equipment, is to distinguish between nonsensitized and scrnsitized material, this can be accomplished most simply, most rapidly, and at lowest cost by an evaluation of oxalic acid etch structures.

Clark has extended the EPR technique to characterize weld heat-affected zones (HAZs) and to correlate degree of sensitization with ]CSCC 
resistance [153]. Current studies are directed toward establishing procedures for, and qualifyir.g, a technique to obtain EPR measurements in situ on reactor components.

In addition to EPR, constant extension rate testing (CERT) has been used to study sensitization effects in 300-scries stainless steels. Note that CERT is also known as SSRT. For example, Povich and Broecker have used CERT in an attempt to study $S C C$ in high-temperature $\left(288^{\circ} \mathrm{C}\right)$, high-pressure $(1500$ psi) water that contained 8 ppm oxygen [154]. The alloys evaluated included Types $304,304 \mathrm{~L}, 316,316 \mathrm{~L}, 347$, and XM-19 (Nitronic 50). Attermpls were made to determine the effects of solution annealing (5A), fumace sensitization (FS), and shot perning (SP) $\mathrm{SA}$ was done al $1100^{\circ} \mathrm{C}$ for $30 \mathrm{~min}$ in argon; samples were quenched in water. FS was done at
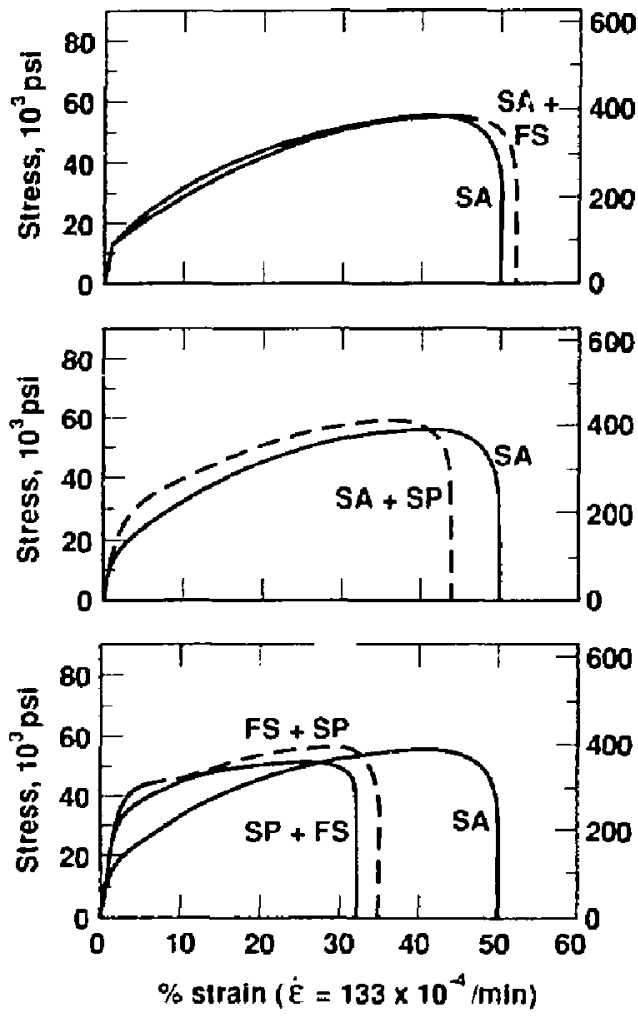

Figure 42. CERT stress-strain results for Type 304L stainless steel in air-saturated water at $288^{\circ} \mathrm{C}$ [154]. SA, solution annealed; $F S_{\text {, furnace- }}$ sensilized; SP, shot peened. $600^{\circ} \mathrm{C}$ for $24 \mathrm{hr}$ in argon; samples were quenched in argon. The strain rate used in the CERT tests was approximately $1.33 \times 10^{-4} \mathrm{~min}^{-1}$. The work required for fracture was then determined by integrating the arca under stress-strain curves (Figs. 42 and 43). From this quantity, a CERT index (CI) is defined: $\mathrm{Cl}=$ the work required to fracture a sample divided by the work required Io fracture a reference sample. Since SA samples failed in a ductile mode and never by SCC. SA samples were used as the reference. Thus, a tof unity indicales no SCC tendency and a $\mathrm{Cl}$ of less than unity indicates that some SCC has occurred.

These investigators concluded thot in the $5 \mathrm{~A}$ condition, only Type 304 exhibited SCC. The mode of cracking was transgranular (TG). The fracture surface was about $15 \% \mathrm{TG}$ and $85 \%$ ductile. In the FS condition, Type 304 exhibited
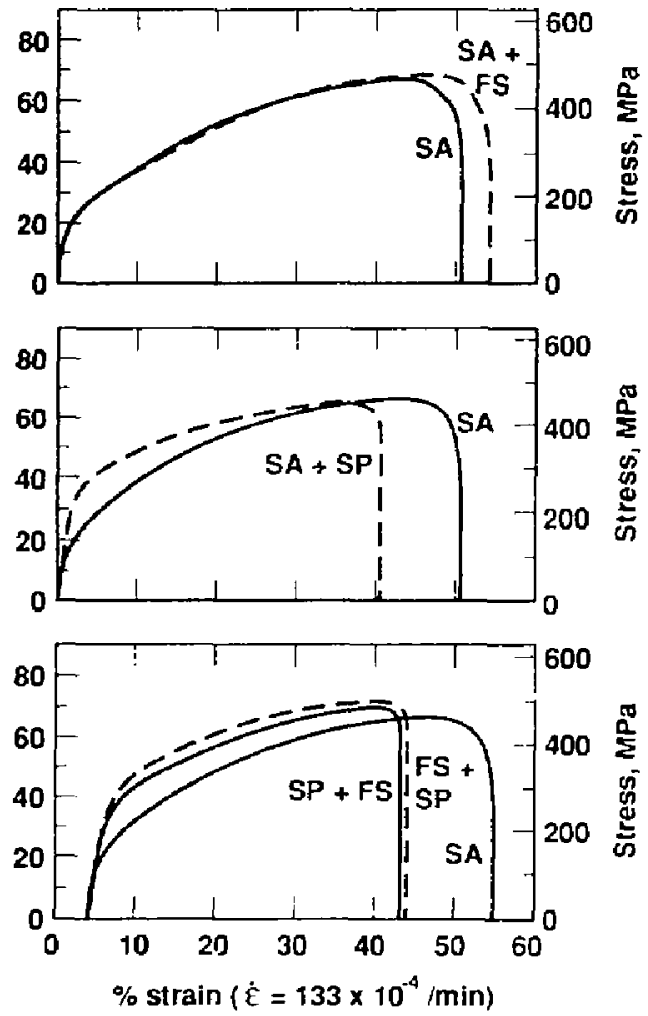

Figure 43. CERT stress-strain results for Type $316 \mathrm{~L}$ stainless steel in air-saturated water at $288^{\circ} \mathrm{C}$ [154]. 
significant intergranular (IG) SCC. There were also signs of TG cracking near the surface. This suggests a TG crack initiation mechanism followed by IG crack propagation. The fracture surface was abou $45 \%$ IG, $5 \%$ TC, and $50 \%$ ductile. Other alloys (Types 304L, 316, 316L, 347, and $X M-19$ ) exhibited only ductile fracture in the SA and FS conditions (no ICSCC or TCSCC was observed). The CIs for alloys in the FS condition are shown in Fig. 44 and range from approximately 1.1 for Type XM-19 to 0.6 for Type 304.

In the SP condition, all alloys exhibited SCC. Significant TCSCC was exhibited in the case of Type 304; the fracture surface was about $50 \%$ TG and $50 \%$ ductile. Some degree of TGSCC was also observed in Types 314L, 316, 316L, and 347. Type XM-19 exhibited only secondary surface cracking; however, the cracks did not propagate. The Cls for alloys in the SP condition are shown in Fig. 45 and range from approximately 0.95 for Type XM-19 to 0.7 for Type 304.

For the FS + SP condition, the FS heat treatment preceded the SP. Both TCSCC and IGSCC were observed for Type 304 in the FS + SP condition. In contrast, significant TGSCC and no IGSCC were observed in Types $304 \mathrm{~L}$ and 347. The absence of ICSCC suggests that there was no grain-boundary sensitization in either Type 304L or 347. No SCC was observed in Types 316, 316L, and XAi-19. The CIs for alloys in the FS + SP condition are shown in Fig. 46 and range from approximately 0.95 for Type XM-19 to 0.6 for Type 304.

For the SP + FS condition, SP preceded the FS heat treatment. TGSCC seemed to initiate IGSCC in Type 304. TGSCC and ICSCC were both observed in Types 304L and 316. Only TCSCC was observed in Type 347. There was very little indication of SCC in Types 316L and XM-19. The Cls for alloys in the SP + FS condition are shown in Fig. 47 and range from approximately 0.9 for Type XM-19 to (0.4 for Type 304. Clearly, SCC effects were most severe for alloys in the SP + FS condition.

Sensitization effects have been cobserved and reported in Types 314 and 316 stainless stcels by numerous investigators. For example, Kowaka et al. also found that a decrease in the carbon markedly reduces the SCC susceptibility of Type 316 stainless steel in high-temperature water [155]. A carbon content of less than $0.02 \%$ is particularly preferable from the viewpoint of superior SCC resistance. This group also found that additions of nitrogen of less than $0.02 \%$ are preferable from the viewpoint of superior SCC resistance. Additions of nitrogen of less than $0.12 \%$ or the presence of phosphorus and sulfur at impurity levels have no detrimental effect on SCC in high-temperature water.

Kudo et al. have studied the corrosion resistance of as-rolled Types 304 and 316 staintess steels for cladding [156]. The cffect of several

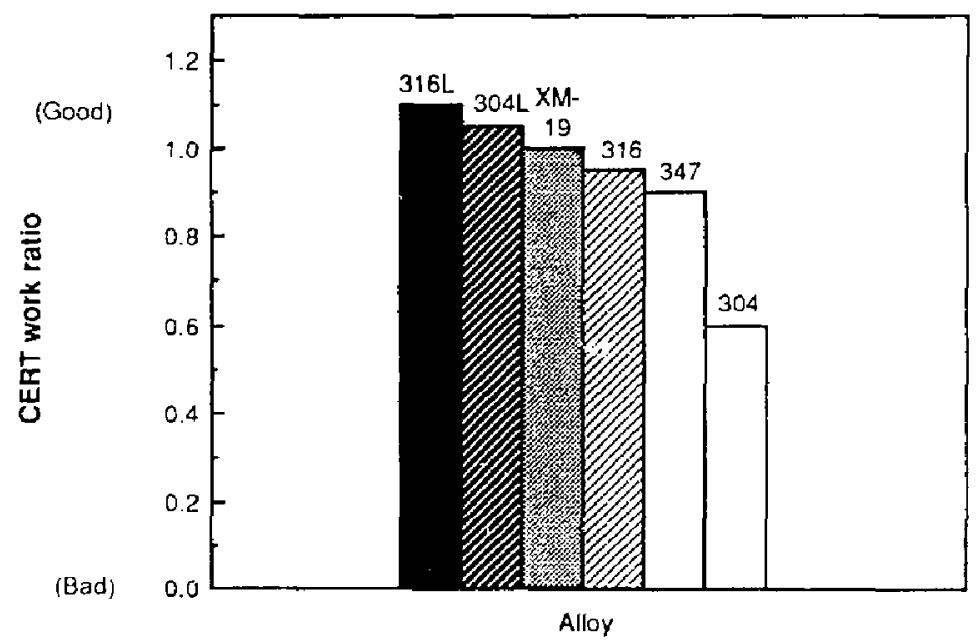

Figure 44. Effect of furnace sensitization on CERT work ratios for various alloys in air-saturated water af $288^{\circ} \mathrm{C}$ [154]. 


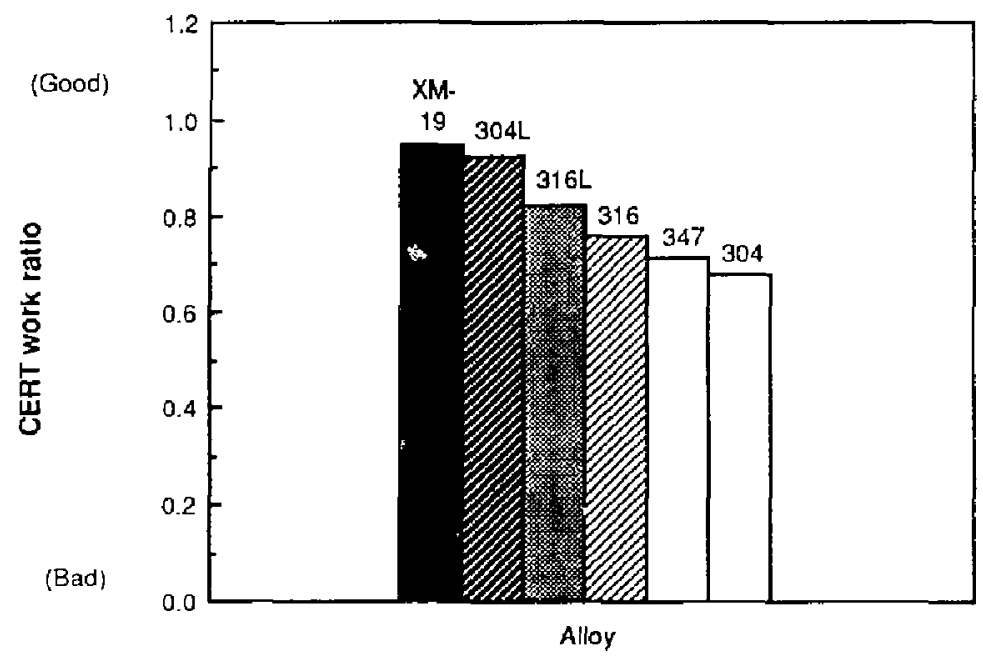

Figure 45. Effect of shot peening on CERT work ratios for various alloys in air-saturated water at $288^{\circ} \mathrm{C}$ [154].

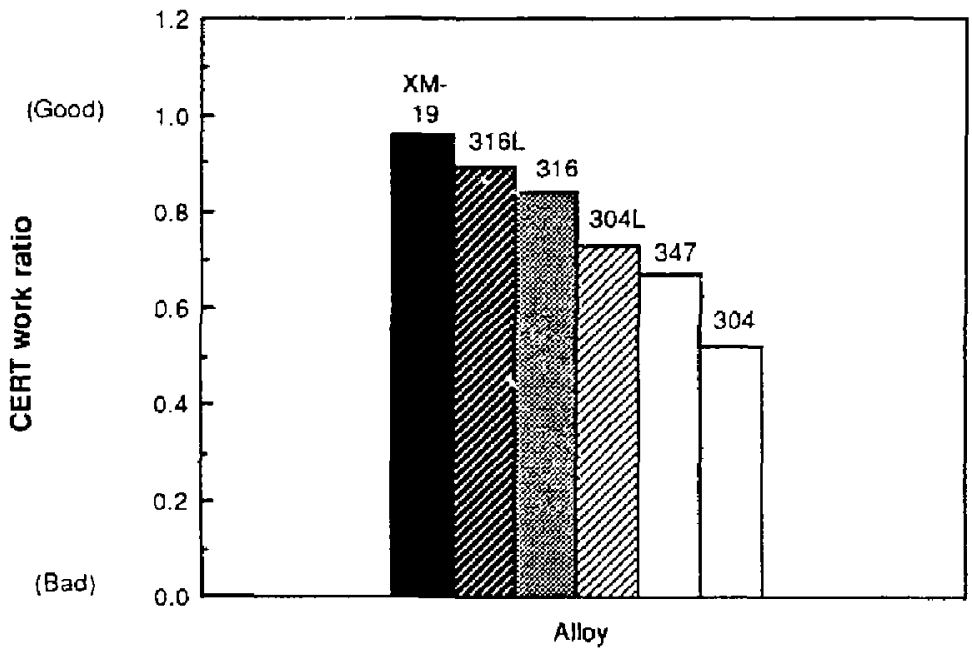

Figure 46. Effect of furnace sensitization followed by shot peening on CERT work ratios for various alloys in air-saturated water at $288^{\circ} \mathrm{C}$ [154].

factors on the corrosion resistance of as-rolled Types 304 and 316 stainless steels for clad use was investigated. No intergranular corrosion occurred on steel with a carbon content below $0.02 \%$. However, long-time heat treatment for stress relief around $650^{\circ} \mathrm{C}$ caused detcrioration of the gencral corrosion resistance of the sted in acids. In order to maintain the resistance of the alloy to general corrosion, Kudo et al. found that it is desirable to reduce the carbon content below $0.01 \%$. The finishing temperature for hot rolling had no significant effect on the corrosion 


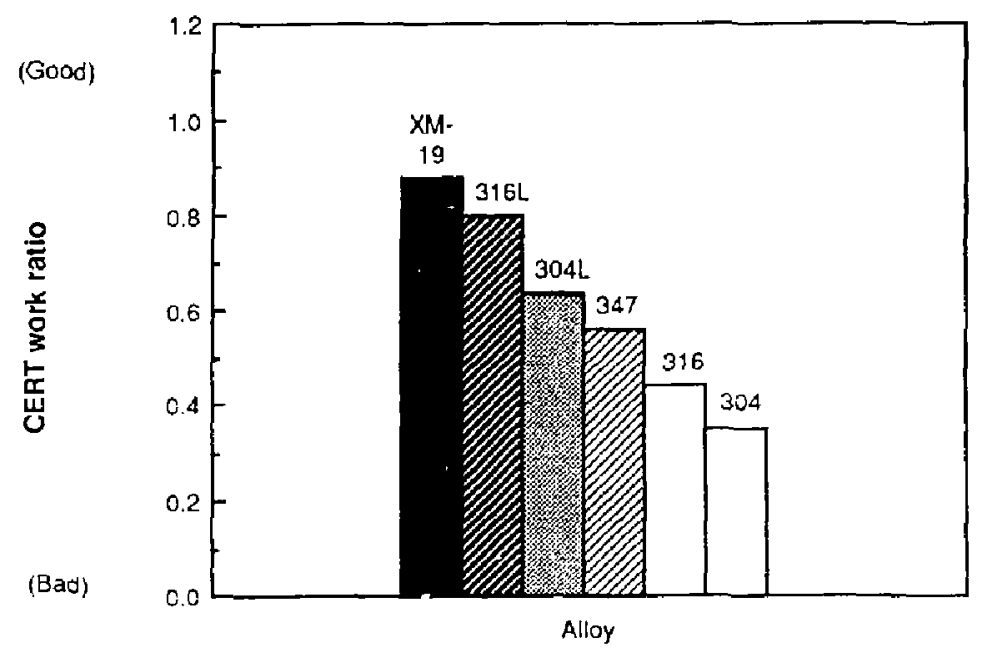

Figure 47. Effect of shot peening followed by furnace sensitization on CERT work ratios for various alloys in air-saturated water at $288^{\circ} \mathrm{C}$ [154].

resistance of steel with carbon content below $0.02 \%$, and the crevice corrosion and SCC resistance of the steel are not inferior to those of solution-treated steels. Carbide precipitation of as-Tolled steels was accelerated as compared with that of solution-trealed steels.

Kass et al. studied the SCC of welded Type 304 stainless steel unce " i loading |157). This study found that decrea...ng the carbon content of weldicd Type 304 stainless stecl results in a marked resistance to IGSCC in cyclic loading tests. Type $304 \mathrm{~L}$ is superior to Type 304 in regard to ICSCC.

Davison et al. reviewed the literature on stainless steels used in heat exchanger applications [158]. They found that the opportunity for intergranular attack is readily eliminated by the selection of low-carbon or stabilized grades. Although it is always recommended that design climinate crevices, it is unlikely that crevices can be completely avoided. In all cases, it is prudent to select a grade of stainless steel that will show crevire corrosion resistance for all reasonably anticipated regimes of operation. SCC can be avoided by the selection of ferritic, duplex, or highly alloyed austenitic grades. Alternatively, grades especially sensitive to SCC, such as Types 304 and 316L. may be used when precautions are taken to eliminate one or more of the factors of SCC, namely stress, chloride, and kemperature. Davison et al. found that for high temperature, the microalloyed austenitic stainless steel Type 253MA provided creep resistance and oxidation resistance superior to those of Type 310. These properties are achieved at a lower total alloy content, thereby reducing cost and suppressing undesirable reactions.

Finally, it is important to note that allows such as Alloys 825,625, and 600 have ackually shown improved corrosion resistance at grain-boundarics afler cold working and heat trealment [159]. For example, samples of these mater-ials were colddrawn to $47 \%$ reduction, then heat-treated at $850^{\circ} \mathrm{C}$ for $] \mathrm{hr}$ and $650^{\circ} \mathrm{C}$ for $1 \mathrm{hr}$. The depth of grain-boundary penctration into heat-treated specimens was approximately $3 \mu \mathrm{m}$ after $120 \mathrm{hr}$ of exposure to boiling $\mathrm{HNO}_{3}$, compared with $390 \mu \mathrm{m}$ of penetration without the heat trearment. These data indicate that Alloy 825 does not undergo sensitization.

\subsection{Effect of Grain-Boundary Segregation on SCC}

Grain-boundary segregation of various impuritics, including phosphorus, sulfur, carbon, siljcon, and nitrogen, has been reported in austenitic stainless steels and can produce a grin boundary that is composed of up to $50 \%$ impurity 
within a 1 - to 2 -mm thick region [16, 172]. Phosphorus segregation has been shown to cause intergranular corrosion in highly oxidizing solutions, and impurity segregation of phosphorus and porhaps silicon has been suggested as a primary factor in irradiationassisted SCC, which necurs in the oxidizing incere environment of light-water reactors [173].

\subsection{Direct Comparison of SCC and Crevice Corrosion Susceptibilities of the Austenitic Candidates}

Asphahani [174] has studied the chloride SCC of all of the austenitic cancidate materials in acidic sodium chloride solutions. Chloride SCC of Types 304, 3041., 316, and 316L was observed in dilute $\mathrm{NaCl}$ solutsons $(0.8$ to $4 \%$ ) containing either $\mathrm{H}_{3} \mathrm{PO}_{4}(0.2$ to $1 \%)$ or $\mathrm{CH}_{3} \mathrm{OOH}(0.5 \%)$. For example, SCC of these austenitic stainless steels could be induced by 10 days of exposure to a solution containing $0.8 \% \mathrm{NaCl}$ and $0.2 \% \mathrm{H}_{3} \mathrm{PO}_{4}$ at a temperature of $141^{\circ} \mathrm{C}$. Pitting and crevice corrosiun were predominant in solutions containing icetic acid.

In sharp contrast to the 300 -scries stainless steels, Asphahani found that the austenitic stainless alloys with higher nickel content, including Alloy 20Cb-3 (Carpenter), Alloy 825, and Alloy 20-Mod (Haynes), are very resistant to chloride stress cracking. However, some pitting and crevice corrosion of these materials were observed, with the exception of Alloy 20-Mod. Asphahani found that the high-performance nickel-based alloys, Alloys G and C-276, show excellent resistance to chloride stress cracking and to localized corrosive attack. The compositions of the alloys investigated by Asphathani are summarized in Table 8 . Figure 48 is a graphic comparison of the compositions of Type 304L, Type 316L, and Alloy 825 extracted from Table 8 .

The SCC lests were conducted on U-bend specimens approximately $133 \times 13 \times 3 \mathrm{~mm}$ in size. Each specimen was deformed around a $25-\mathrm{mm}$ mandrcl and then further stressed by straining its ends (tightening a nut and bolt) to a final span of $12 \mathrm{~mm}$. The imposed stress depended on the yield strength of the moterial, and no effort was made to calculate the exact value of the applied stress. Samples were exposed to the acidic sodium chloride solutions at $141^{\circ} \mathrm{C}$ in sealed Alloy C-276 autoclaves.

The following results were obtained after a I-month exposure to a solution containing 4\% $\mathrm{NaCl}$ and $1 \% \mathrm{H}_{3} \mathrm{PO}_{4}$ [Table 9(a)]. The SCC observed in the 300-series specimens (Types 304, $3124 \mathrm{~L}, 316$, and $316 \mathrm{~L}$ ) was of the branching. transgranular type (TGSCC). Furthermore, severe erevice corrosion was observed under the nut and the head of the bolt used for stressing these samples. Alloy 20Cb-3 suffered severe pitting and crevice corrosion but no SCC. Alloy 825 showed only slight crevice corrosion and was completely resistant to SCC. Alloys 20-Mod, G, and $C-276$ all demonstrated outstanding resistance to both localized attack and SCC. In fact, it is interesting to note that Alloy C-276 had been selected as the autoclave material. Sinilar results were observed in more dilute selutions of sodium chloride and phosphoric acid, except that

Table 8. Nominal compositions of alloys tested (wt\%).

\begin{tabular}{|c|c|c|c|c|c|c|c|c|}
\hline Alloy & $\mathrm{Fe}$ & $\mathrm{Ni}$ & $\mathrm{Cr}_{\mathrm{r}}$ & Mo & $\mathrm{Mn}$ & $S i$ & $\mathrm{Cu}$ & $\mathrm{C}$ \\
\hline 304 & Bal & 9 & 19 & - & $2^{a}$ & $1^{3}$ & - & 0.05 \\
\hline $304 \mathrm{~L}$ & Bal & 9 & 19 & - & $2^{a}$ & $1^{\mathrm{a}}$ & - & 0.05 \\
\hline $304 \mathrm{~L}$ & Bal & 9 & 19 & - & $2^{0}$ & $1^{3}$ & - & $0.03^{\mathrm{a}}$ \\
\hline 316 & Bal & 12 & 17 & 2.5 & $2^{a}$ & $1^{3}$ & - & 0.05 \\
\hline $316 \mathrm{~L}$ & Bal & 12 & 17 & 2.5 & $2^{\mathrm{a}}$ & $1^{3}$ & - & $0.03^{a}$ \\
\hline $20 \mathrm{Cb}-3$ & Bal & 33 & 20 & 2.5 & $2^{a}$ & $1^{\mathfrak{a}}$ & 3 & 0.04 \\
\hline 825 & 30 & Bal & 21 & 3 & $1^{a}$ & $0.5^{3}$ & 2 & 0.04 \\
\hline 20-Mod & Bal & 26 & 22 & 5 & $2.5^{\mathrm{a}}$ & $1^{2}$ & 一 & $0.05^{3}$ \\
\hline G & 20 & Bal & 22 & 7 & 1.5 & 1 & 2 & $0.05^{\mathrm{a}}$ \\
\hline$C-276$ & 5 & Bal & 16 & 16 & $1^{d}$ & $0.8^{\mathrm{a}}$ & - & $0.02^{\mathrm{a}}$ \\
\hline
\end{tabular}

a Maximum concentration. 


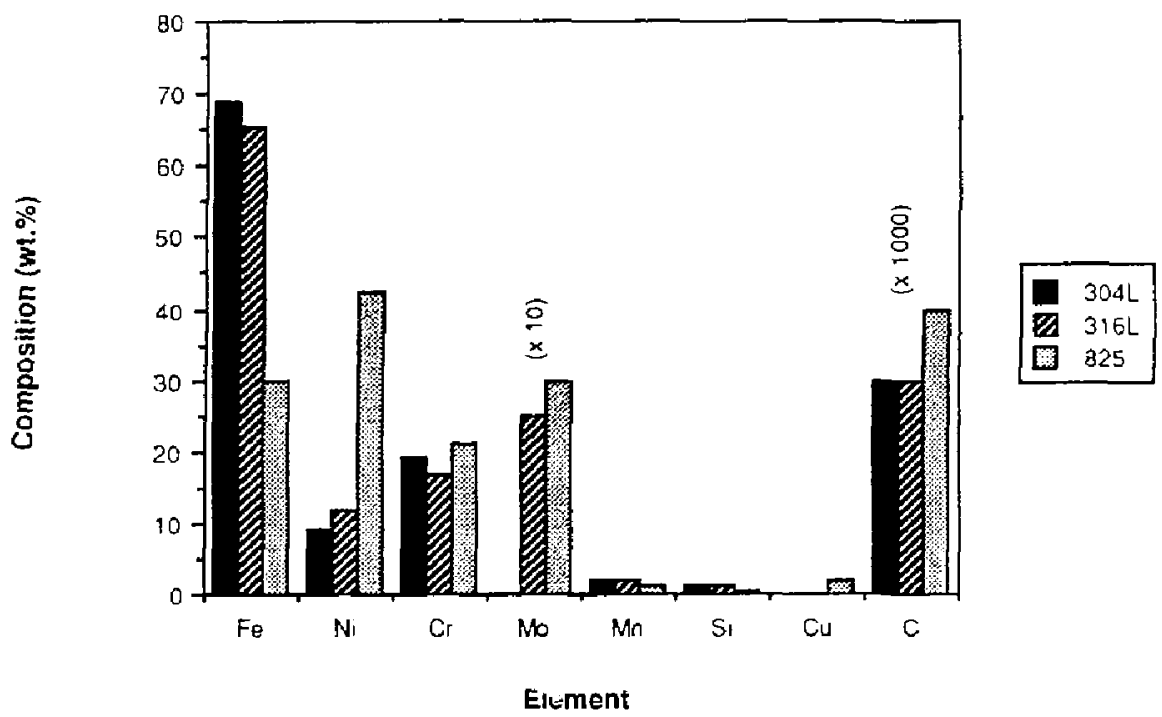

Figure 48. Nominal compositions for the austenitic candidate materials [174].

Ihe attack of the Alloy 825 was slightly worse [Table $9(\mathrm{~b})$ ].

Asphahani also conducted experiments in a solution of $0.8 \% \mathrm{NaCl}+0.5 \% \mathrm{CH}_{3} \mathrm{COOH}$ [Table 9(c)]. Again, branching TGSCC was observed for the 300-series alloys. Acetic acid tended to increase the pitting and crevice corrosion of the specimens. The results of this series of tests indicated that SCC of the Types 304, $304 \mathrm{~L}, 316$, and $316 \mathrm{~L}$ stainless steels was not limited only to the chloride solutions containing $\mathrm{H}_{3} \mathrm{PO}_{4}$.
Finally, Aspl:anani's results for a solution of $\mathrm{NaCl}$ and $\mathrm{HCl}$ are presented [Table 9(d)]. SCC was observed in the 300 -series alloys after 30 days of exposure; no SCC was observed in Alloy 825 or the alloys with higher nickel content. All specimens with no cracking after the 10-day exposure were further tested for an additional 20-day exposure [Table 9 (d)]. The temperature of the container was maintained at $285^{\circ} \mathrm{C}$. The container developed a leak at the seal, and the test solution evaporated some time near the end of the testing period.

Table $9(a)$. U-bend specimens after 1 month in $4 \% \mathrm{NaCl}$ and $1 \% \mathrm{H}_{3} \mathrm{PO}_{4}$ at $141^{\circ} \mathrm{C}$.

\begin{tabular}{lclc}
\hline Alloy & $\begin{array}{c}\text { Corrosion rate } \\
(\mathrm{mm} / \mathrm{yr})\end{array}$ & \multicolumn{1}{c}{ Localized corrosion } & SCC \\
\hline 304 & 0.15 & Crevice corrosion & Yes \\
$304 \mathrm{~L}$ & 0.13 & Crevice corrosion & Yes \\
316 & 0.11 & Crevice corrosion & Yes \\
$316 \mathrm{~L}$ & 0.04 & Slight attack & Yes \\
$20 \mathrm{Cb}-3$ & 0.07 & Crevice corrosion and pitting & No \\
825 & $<0.01$ & Slight attack & No \\
$20-$ Mod & $<0.01$ & No attack & No \\
G & $<0.01$ & No attack & No \\
C-276 & $<0.01$ & No attack & No \\
\hline
\end{tabular}


Table 9(b). U-bends after 1 month in $0.8 \% \mathrm{NaCl}$ and $0.2 \% \mathrm{H}_{3} P \mathrm{O}_{4}$ at $141{ }^{\circ} \mathrm{C}$.

\begin{tabular}{|c|c|c|c|}
\hline Alloy & $\begin{array}{c}\text { Corrosion rate } \\
\text { (mm/yr) }\end{array}$ & Localized corrosion & SCC \\
\hline 304 & $0.14^{\mathrm{a}}$ & Crevice comasion & Yes \\
\hline $304 \mathrm{~L}$ & $0.03^{\mathrm{a}}$ & Crevice corrosion & Yes \\
\hline 316 & $0.02^{\mathrm{a}}$ & Crevice corrosion & Yes \\
\hline $316 \mathrm{~L}$ & $0.01^{\mathrm{a}}$ & Slight attack & Yes \\
\hline $20 \mathrm{Cb}-3$ & 0.07 & Crevice corrosion and pitting & No \\
\hline 825 & 0.03 & Crevice corrosion and pitting & No \\
\hline 20-Mod & $<0.01$ & No attack & No \\
\hline$G$ & $<0.01$ & No attack & No \\
\hline$C-276$ & $<0.01$ & Noattack & No \\
\hline
\end{tabular}

S Specimen removed after 10 days.

Table $9(\mathrm{c})$. U-bend specimens after 1 month in $0.8 \% \mathrm{NaCl}$ and $0.5 \% \mathrm{CH}_{3} \mathrm{COOH}$ AT $141^{\circ} \mathrm{C}$.

\begin{tabular}{lccc}
\hline Alloy & $\begin{array}{c}\text { Corrosion rate } \\
(\mathrm{mm} / \mathrm{yr})\end{array}$ & Localized corrosion & SCC \\
\hline 304 & 0.03 & Severe pitting & Yes \\
$304 \mathrm{~L}$ & 0.02 & Severe pitting & Yes \\
316 & 0.01 & Severe pitting & Yes \\
$316 \mathrm{~L}$ & $<0.01$ & Pitting & Yes $^{\mathrm{a}}$ \\
$20 \mathrm{Cb}-3$ & $<0.01$ & No attack & No \\
825 & $<0.01$ & No attack & No \\
$20-\mathrm{Mod}$ & $<0.01$ & No attack & No \\
G & $<0.01$ & No attack & No \\
C-276 & $<0.01$ & No attack & No \\
\hline
\end{tabular}

I One specimen out of two cracked.

Table 9(d). U-bend specimens in $0.8 \% \mathrm{NaCl}$ and $\mathrm{HCl}(\mathrm{pH} 2.2)$ at $141^{\circ} \mathrm{C}$.

\begin{tabular}{lcc}
\hline Alloy & 10-day exposure & 30-day exposure \\
\hline 304 & No cracking & Cracking \\
$304 \mathrm{~L}$ & No cracking & Cracking \\
316 & No cracking & Cracking \\
$316 \mathrm{~L}$ & No cracking & Cracking \\
20Cb-3 & No cracking & No cracking \\
825 & No cracking & No cracking \\
20-Mod & No cracking & No cracking \\
6 & No cracking & No cracking \\
C-276 & No cracking & No cracking \\
\hline
\end{tabular}


As Asphahani noted, it is surprising that phosphoric or acetic acids cause localized corrosion and SCC of stainless stecis in dilute chloride solutions. Phosphates and acetates have been known to inhibit corrosion and SCC. For example, $\mathrm{NaH}_{2} \mathrm{PO}_{4}$ additions to $\mathrm{NaCl}$ solutions inhibit the SCC of high-strength, low-alloy steels [1751. Similarly, $\mathrm{CH}_{3} \mathrm{COOH}$ additions to boiling $\mathrm{MgCl}_{2}$ solutions have proven effective in inhibiting the SCC of 18-8 stainless steel [176].

Asphahani also performed experiments in which Type 316L specimens were galvanically coupled to other alloys close in performance or more noble (Types 3ith and 316, Alloys $20 \mathrm{Cb}-3$ and $G$, efc.). The cortosion potential, $E_{\text {corr }}$ of Type 316L was shifted to more noble values above the critical pitting potential, $E_{\mathrm{c}}$, and within the susceptible polfential range for cracking.
The exceptional corrosinn resistance of the high-performance nickel-based alloys is believed to be due to both their high nickel and high molytadenum contents. For example, not only are Alloy $\mathrm{G}$ and $\mathrm{C}-276$ immune to $\mathrm{SCC}$ in the acidic sodium chloride solutions discussed here, they are also immune to SCC in boiling $42 \% \mathrm{MgCl}_{2}$ solutions. While carbon content and molybdenum addition do not improve the performance of the 3) (1): cries stainless steels, increasing the molybdenum content of the highchromium, high-nickel stainless alloys, such as 20Cb-3, Alky 825, and 20-Mod plays a definite role in imploving their resistance to localized altack and SCC. This finding is consistent with the discussion above.

\section{Unusual Environmental Effects in the Repository: Gamma Irradiation and Biological Corrosion}

Thi metal bartiers used for high-level nuclear wastes will be exposed to high fluxes of gamma radiation. Therefore, the effect of gamma radiation on SCC must be considered. Furthermore, the barricrs will have to remain intact for scveral thousand years. Consequently, it is also necessary to consider other corrosion scenarios that may arise over extended periods of time, such as microbiologically induced corrosion (MIC).

\subsection{General Effects of Gamma Irradiation}

It has been known for many years that the irradiation of liquid water by gamma rays produces ionic, free radical, and molecular products. Berauce of the fast reaction of ionic species, the "primary products" of water radiolysis are considered to be $\mathrm{H}^{+}, \mathrm{OH}^{-}, \mathrm{caq}^{-}, \mathrm{HO}_{2}, \mathrm{H}_{2} \mathrm{O}_{2}$, and $\mathrm{H}_{2}$. where the first four are called the radical products, and the last two are the molecular products. The radical products are very chemically reactive. with the molecular products or with dissolved solutes in the water, if present. If oxygen is dissolved in the water, both $H$ and $e_{a q}^{-}$seact with it rapidly to form $\mathrm{HO}_{2}$ and $\mathrm{O}_{2}$, respecively. At pH near neutral, the $\mathrm{HO}_{2}$ ionizes rapidly to form $\mathrm{H}^{*}$ and $\mathrm{O}_{2}$. The result of all these reactions is that in ir radiated oxygenated water, one has steady-state concentrations of the oxidizing species $\mathrm{OH}, \mathrm{O}_{2}$, and $\mathrm{H}_{2} \mathrm{O}_{2}$. One also has a low steady-state concentration of $\mathrm{H}_{2}$ (which is effectively inert to stainiess steel at temperatures at which water is liquid).

When one inserts an elcetrode into such an irradiated solution, one observes a corrosion potenlial, $E_{\mathrm{cor} r}$, which reflects the composite of the reactions of all the reactive species in the solution with the material of the electrode. Several research groups, including Class et a]. [177, 178], Marsh et al. [179|, Kim and Oriani [180, 181], Clarke and Jacobs [182], and Ruther et a). [183] have observed that $E_{\text {corr }}$ of stainiess stecl shifts to mure posilive (noble) values in the presence of gamma irradiation.

The initial understanding of this radiolvtic effect on corrosion potent ial is attributed to Glass et al. of the Nevada Nuclear Waste Storage Invesligations Project. This study found that the positive shift in $E_{\text {conr }}$ was composed of threc parts. The major part was found to persist after the irfudiation was terminated, but most of it was removed if the irradiated solution was replaced by a new solution. This pari was allributed to hydrogen peroxide, $\mathrm{H}_{2} \mathrm{O}_{2}$. The part that remained after the solution was changed was attributed to permanent changes in the oxide layer on the stainless steel. The third part was nnly present during irradiation and was attributed to the transicnt radical species. 
According to Glass et al, the following anodic and cathodic reactions are believed to be of major importance in determining the corrosion potentials of austenitic stainless stcels under gamma irradiation [17]]. First, the cathodic reactions are:

$\mathrm{H}_{2} \mathrm{O}_{2} \rightarrow 2(\cdot \mathrm{OH})_{\wedge D S}$

$(\cdot \mathrm{OH})_{\mathrm{ADS}}+\mathrm{v}^{-} \leftrightarrow \mathrm{OH}^{-}$

$\mathrm{O}_{2}+2 \mathrm{H}_{2} \mathrm{O}+4 \mathrm{e}^{-} \rightarrow 4 \mathrm{OH}^{-}$

$\mathrm{O}_{2}^{-}+\mathrm{H}_{2} \mathrm{O}+\mathrm{C}^{-} \rightarrow \mathrm{HO}_{2}^{-}+\mathrm{OH}^{-}$

$\mathrm{HO}_{2}^{-}+\mathrm{H}_{2} \mathrm{O}+2 \mathrm{c}^{-} \rightarrow 3 \mathrm{OH}^{-}$

where ADS denotes adsorbed species. Equation (30), not given explicilly by Glass et al., has been included for completent'ss. The reactions represented by Eqs. (33) and (34) are believed to be relatively less important than reactions represented by Eqs. (31) and (32). The cathodic reactions are:

$\mathrm{Fe} \rightarrow \mathrm{Fe}^{2+}+2 \mathrm{e}^{-}$

$\mathrm{Cr} \rightarrow \mathrm{Cr}^{3+}+3 \mathrm{c}^{-}$

$\mathrm{Ni} \rightarrow \mathrm{Ni}^{2+}+2 \mathrm{e}^{-}$

The coupling of the cathodic processes with metal dissolution reactions results in the observed mixed corrosion potential, $E_{\text {corr }}$. The effect of a single radiolysis product such as hydrogen peroxide on the corrosion potential can be understood by comparing its reduction potential with that of the usual depolarizer, dissolved oxygen (DO) [184\}.

$\mathrm{H}_{2} \mathrm{O}_{2}+2 \mathrm{H}^{+}+2 \mathrm{e}^{-} \rightarrow 2 \mathrm{H}_{2} \mathrm{O}(1535 \mathrm{mV}, \mathrm{SCE})$

$\mathrm{O}_{2}+4 \mathrm{H}^{+}+4 \mathrm{c}^{-} \rightarrow 2 \mathrm{f}_{2} \mathrm{O}(988 \mathrm{mV}, \mathrm{SCE})$

Preferential reduction of hydrogen peroxide would shift the corrosion potential to more positive values; it is evident that hydrogen peroxide is a more effective depolarizer than oxygen. Such changes in the corrosion potential tend to decrease the difference $E_{c}-E_{\text {corr }}$, thereby decreasing the material's resistance to pitting and SCC. Note that Glass et al. found that gamma irradiation had little effect on the pilting potential [177].

Marsh et al. found increases in $E_{\text {corr }}$ for both oxygenated and de-oxygenated solutions, but the de-oxygenated solutions responded more slowly [179]. This study concluded that the increase was caused by oxidizing radicals and molecular species, and that the presence of oxygen enhances the production of oxidizing products. Furthermore, this study found that irradiation inhibits the initiation of localized corrosion at relatively low electrode polentials. It was tentatively suggested that this inhibition occurs because the adsorption of oxidizing radiolysis products enhances the protective properties of the passivate oxide film.

The primary effect of gamma irradiation is probably to form the free radicals $\mathrm{H}^{+}$and $\mathrm{OH}^{-}$ [180, 181]. These free radicals also react with one another to some extent to form $\mathrm{H}_{2}, \mathrm{O}_{2}$, and $\mathrm{H}_{2} \mathrm{O}_{2}$. Some of the radicals escape from the radiolysis zone and react with dissolved $\mathrm{H}_{2}, \mathrm{O}_{2}$, and $\mathrm{H}_{2} \mathrm{O}_{2}$ molecules in the solution to lead to the reformation of water. This concept is not original with Kim and Oriani. Radiation chemistry is discussed in detail by Spinks and Woo:s [ 185 ].

\subsection{Effects of Gamma Irradiation on SCC of Stainless Steels}

Intergranular stress corrosion cracking (1CSCC) was observed in 1967 in the heat-affected zone (HAZ) of Type 304 stainless steel piping uscd in the recirculation circuit of a BWR [186]. Since then, the problem has been found in many reactors of this type.

It is widely recognized that IGSCC occurs in stainless steels when three conditions are simultaneously present: (1) the material must be sensi(ized, i.e., the concentration of dissolved chromium in the grain boundaries must be depleted to less than 12 wt \% by the formation of chromium carbide precipitates, (2) the material must be placed under sufficient tensile stress, and (3) the environment must be sufficiently corrosive to attack the material in the grain boundaries. Since gamma irradiation of aqueous solutions produces several oxidizing and reducing species by radiolysis, it might be expected to affect SCC.

Fujita et al. performed constant extension rale trists (CERTs) on sensitized TYpe 304 stainless sted with and without exposure to gamma rays in high-temperature water that had been purified by an ion exchanger [186]. The CERT results are shown in Table 10. Two different DO concestrations were investigated: $D O<20 \mathrm{ppb}$ and $\mathrm{DO}=8 \mathrm{ppm}$. The chloride cons , itrations were 
Table 10. Results obtained from CERT tests of Type 304 stainless steel under gamma irradiation.

\begin{tabular}{|c|c|c|c|c|c|c|}
\hline \multirow[b]{2}{*}{$\begin{array}{l}\text { Gamma } \\
\text { irsadiation }\end{array}$} & \multirow[b]{2}{*}{ DO } & \multirow{2}{*}{$\begin{array}{l}\text { Lead } \\
\text { time } \\
\text { (days) }\end{array}$} & \multicolumn{4}{|c|}{ At fracture } \\
\hline & & & $\begin{array}{l}\text { Time } \\
\text { (hr) }\end{array}$ & $\begin{array}{c}\text { Elong. } \\
\text { (mm) }\end{array}$ & $\begin{array}{c}\text { Strain } \\
(\%)\end{array}$ & $\begin{array}{c}\text { Stress } \\
\left(\mathbf{k g} / \mathrm{mm}^{2}\right)\end{array}$ \\
\hline No & $\leq 20 \mathrm{ppb}$ & 0 & 109 & 6.54 & 32.7 & 39.9 \\
\hline Yes & $\leq 20 \mathrm{ppb}$ & 0 & 110 & 6.60 & 33.0 & 39.2 \\
\hline No & $\leq 20 \mathrm{ppb}$ & 5 & 112 & 6.72 & 33.6 & 39.4 \\
\hline Yes & $\leq 20 \mathrm{ppb}$ & 5 & 120 & 7.20 & 36.0 & 39.8 \\
\hline No & $8 \mathrm{ppm}$ & 0 & 55 & 3.30 & 16.5 & 30.6 \\
\hline Yes & $8 \mathrm{ppm}$ & 0 & 36 & 2.16 & 10.8 & 22.3 \\
\hline No & $8 \mathrm{ppm}$ & 5 & 112 & 6.72 & 33.6 & 39.7 \\
\hline Yes & 8 ppm & 5 & 119 & 7.14 & 35.7 & 39.0 \\
\hline
\end{tabular}

Note: the test environment was highly purified water at $250 \mathrm{C}$ and $50 \mathrm{Ml} d$; the extencion rate was $1 \times 10^{-3} \mathrm{~mm} / \mathrm{min}$.

not reported. The gamma-ray dose rate was $4.5 \times$ $10^{4} \mathrm{R} / \mathrm{hr}$, the temperalure was $250^{\circ} \mathrm{C}$, and the flow rate was $2 \times 10^{4} \mathrm{~cm}^{3} / \mathrm{min}$, with an autoclave volume of $550 \mathrm{~cm}^{3}$. The samples hid been solution heat-treated at $1050^{\circ} \mathrm{C}$ for $30 \mathrm{~min}$ and sensitized at $650^{\circ} \mathrm{C}$ for $2 \mathrm{hr}$ in vacuum. The strain rates during the tests ranged between $4 \times 10^{-7} 5^{-1}$ and $4 \times 10^{-6} \mathrm{~s}^{-1}$.

Fujita et al. found that under the low-oxygen conditions ( $<20 \mathrm{ppb}$ ), the specimens failed ductilely whether or not they were gamma-irradiated. The strain at fracture was slightly higher under irradiation, while the maximum stress was about the same. It was therefore concluded that under these conditions the gamma irradiation actually had a slight protective effect. Under the higheroxygen conditions (8 ppm), Fujita et al. found that specimens that had been pre-oxidized in the test environment for 5 l 1010 days withoul applied load also exhibited ductile failure during subsequent CERT testing, whether or not they were irradiated. In this case, gamma irradiation again gave some increase in the strain at fracture. How'ever, specimens that were not pre-oxidized showed IGSCC both with and without irradiation under the high-DO conditions and had greatly reduced fracture strains. Moreover, in this case, gamma irradration was delelerious, giving 2510 $34 \%$ lower fracture strains.

In 1985 Ishigure el al. reported on an extension of this work to include intermediate values of the sixygen concentration [187]. This study found that the failure's were ductile for concentrations up to $200 \mathrm{ppb}$ of oxygen. At $500 \mathrm{ppb}$ and above, ICSCC was observed. The effect of gamma irradiation was slightly berneficial (i.e., higher fracture strains were found) for oxygen concentrations up to and including $500 \mathrm{ppb}$, but the irradiation produced lower fracture strain at 8 ppm oxygen, as mentioned above. Ishigure et al also observed that the addition of $\mathrm{H}_{2} \mathrm{O}_{2}$ with irradiation increased the fracture strain. Addition of $\mathrm{H}_{2}$ improved (increased) the fraclure strain without irradiation, and was even more beneficial with ir radiation.

Kuribayashi and Okabayashi conducted experiments to examine the influence of gamma irradiation on SCC of sensitized austenitic stainless steel [188]. The SCC tests were conducted with gamma irradiation in boiling $12 \% \mathrm{NaCl}$ solution, $\mathrm{pH}$ adjusted to 3 with $\mathrm{HCl}$, and a hightemperature pure water $\left(230^{\circ} \mathrm{C}\right)$. In this study, it was found that gamma irradiation increased IGSCC susceptibility of sensitized Type 304 stainless stecl in the acidic $\mathrm{NaCl}$ environment. Ferric ions $\left(\mathrm{Fe}^{3+}\right)$ are radialytically formed by gamma irradiation from ferrous ions $\left(\mathrm{F}^{2+}\right)$ in acid solution, and this phenomenon is the widely known principle of the Fricke dosimeter. The ferric ions may act as a strong oxidizing agent and may increase the susceptibility to ICSCC in the boiling acid chloride solution. Furthermore, gamma radiation also increased IGSCC susceptibility of sensitized Type 304 sted in hightemperature oxygenated pure watcr.

Furuya et al. reported experiments on the effects of gamma irradiation on SCC in boiling deionized water $|46|$. The alloys studied were Types 304, 304 L, 304EL, and 3095 stainless steels, Alloys 825, 60), and 625, and SMA 50 (a low-alloy stecl containing small amounts of manganese and copper). The materials were sensitized by heat 
treatments at $700^{\circ} \mathrm{C}$ for 100 min and then at $500^{\circ} \mathrm{C}$ for $24 \mathrm{hr}$. The samples were formed into double $U$-bends, some with $V$-notches. All the materials were included in the first test series, which lasted 180 days. Furuya et al. found that the samples made of Types 304, 304L, and 3095 exhibited SCC. while the others (Type 304EL, Alloys 825, 60), and 625, and SMA 50) did not. This was found to be the case both with and without gamma irradiation, but the number of failures with Type 304, particularly at $V$-natches, was much greater for the irradiated samples. The chloride eoncentrations in the first series were between 0.2 and $3.8 \mathrm{Fpm}$.

Furuya et al performed a second series of tests on Type 304 only, in which care was taken to kCep the chloride and DO at lower concentrations by using a closed refluxing system rather than a fowing system. In this series, which ran for 60 days, ICSCC was observed on the irradiated samples but not on the unimadialed ones. The chloride conceutrations were less than $0.7 \mathrm{ppm}$ in this series. The oxygen concentrations were not reporled. Figure 49 illustrates the effects of gamma irradiation on SCC observed by Furuya et al.
It is difficult to harmonize the results of Fujita et al. and lshigure et al. with those of Furuya et al. Fujita et al. found a slight beneficial effect of gamma irradiation on IGSCC in sensitized Type 304 stainless sted when the oxygen concentration was minimized, whilc Furuya el al. found a strong deleterious effect under conditions that presumably minimized the oxygen concentration. However, the first group used liquid water at $250^{\circ} \mathrm{C}$, while the second group used boiling water, presumably at $100^{\circ} \mathrm{C}$. Alsa, since the first group did not specify the chlonde concentration, it is difficult to ascertain that the same chemical conditions prevailed in the two sets of experiments. It can be concluded though, that both groups observed cffects of gamma irradiation on IGSCC in sensitized Type 304 stainless steel under some conditions. Note that Kuribayashi and Okabayashi also observed an enhancement of SCC by gamma irradiation in acidic $\mathrm{NaCl}$ solutions and in oxygenated water. In contrast to the delcterious effects of gamma irradiation on Type 304 stainless steel, Furuya et al. found that gamma irradiation had little effect no Alloy 825.

Kikuchi ct al. performed SCC experiments using solutions of $\mathrm{O}_{2}$ and $\mathrm{H}_{2} \mathrm{O}_{2}$ wilhout irradiaticn [189].

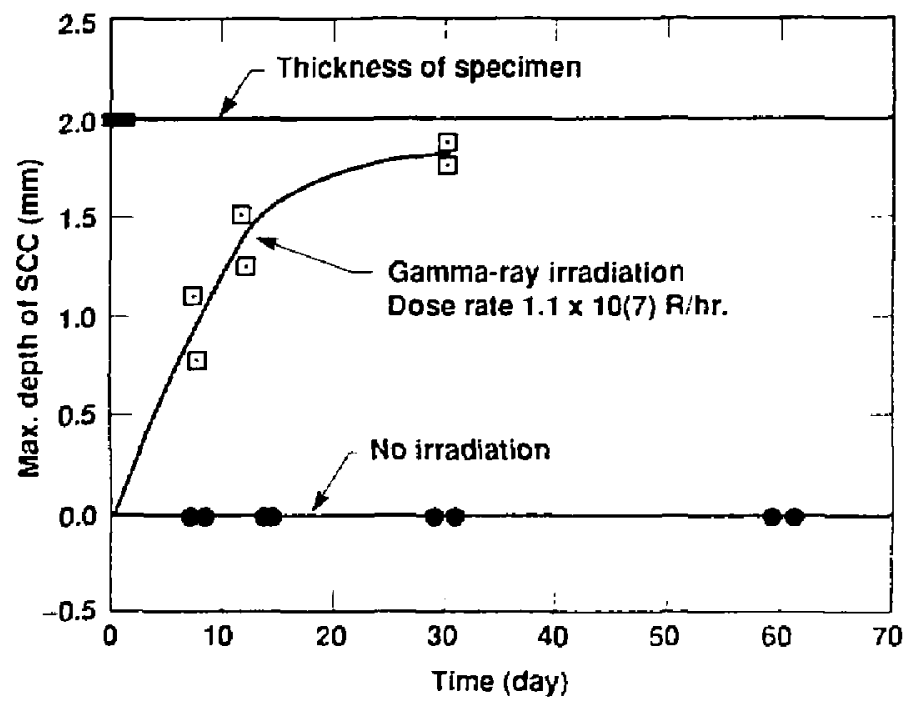

Figure 49. Effects of gamma-ray irradiation on SCC failures of sensitized Type 304 stainless steel [47]. 
In this study, it was found that $\mathrm{H}_{2} \mathrm{O}_{2}$ can effectively inhibit the formation of IGSCC caused by DO, and that the threshold concentration of $\mathrm{H}_{2} \mathrm{O}_{2}$ needed to inhibit ICSCC increases with increased concentration of dissolved $\mathrm{O}_{2}$.

It should be noted that nuclear-waste containcrs will not ox subjocted to significant fuences of reutrons. Howevir, it is of interest that a program has been conducied by Clarke and Jacobs to study the effects of prior neulron imadiation on the effects of gamma irradiation on the SCC behavior of Type 304 stainiess steel in hightemperalure water [182]. A series of CERT tests were completed at $288^{\circ} \mathrm{C}$ in oxygenated water on annealed materials machined from neutranirradiated reactor components. These tests confirmed that high fluences of prior neutron irradiation promote 1CSCC in Type 304 stainless stecl, and that a threshold fluence exists for high plastic-strain levels at about $5 \times 10^{20} \mathrm{n} / \mathrm{cm}^{2}$ $(E>1 \mathrm{MeV}$. An experiment was also conducted to measure the electrochemical potential (ECP) of stainless steel in oxygenated $288^{\circ} \mathrm{C}$ water as a radiation source was moved closer to the electrode surface.

On the basis of the results developed during this study, the following generalized conclusions were made. First, the results of the CERT testing of annealed and irradjated Type 304 stainless steel material reveal an irradiation effect on IGSCC resistance. A sample irradiated to $3 \times 10^{21} \mathrm{n} / \mathrm{cm}^{2}$ ( $E>1 \mathrm{McV}$ ) and then CERT-tested in $288^{\circ} \mathrm{C}$ water with 32 to $36 \mathrm{mg} / /$ DO failed entirely by ICSCC. A companion specimen irradiated to $1 \times 10^{18}$ $\mathrm{n} / \mathrm{cm}^{2}$ and tested identically to the above failed in a ductile mode. This result is highly significant, as similar testing of nonirradiated, annealed Type 304 stainless steel in high-temperature oxygenated water had never produced JGSCC in this material. Second, testing of reactor-irradiated tube material, after high in-reactor fluence accumulation, confirmed the irradiation-assisted SCC effect noted for the plate material. In addition, CERT tests conducted on the absorber-tube samples indicated a threshold neutron fluence of about $5 \times 10^{2 n} \mathrm{n} / \mathrm{cm}^{2}$ for irradiation-assisted SCC at high strain levels. Third, a 25 -fold increase in strain rate, from $4 \times 10^{-6} / \mathrm{min}$ to $1 \times 10^{-4} / \mathrm{min}$, can reduce the amount of IGSCC in high-fluence specimens from 100 ) to $40 \%$. James [190)] discussed the effects of gamma irradiation on various candidate materials for high-level radioactive wastle storage and found that imadiatum had very little influence on SCC resistance.
Finally, it was found that the ECP of stainless steel hecame more noble ( $150 \mathrm{mV})$ over the stcady-state potential as a gamma-radiation source was moved very close to the electrode. This finding is consistent with the work of Class et al. $[177,178]$. The significance of this finding is that the effect of gamma irradiation on the water close to the electrode surface is to move the ECP into a region where IGSCC is more likely to occur. However, this high gamma-radiation level cannot be the sole contributor to IGSCC initiation and propagation since a sample exposed to a kw neutron fluence $\left(1 \times 10^{18} \mathrm{n} / \mathrm{cm}^{2}\right)$ failed ductilely when CERT-tested in a manner that produces ICSCC in high-fluence material $\left.(>5 \times] 0^{20} \mathrm{n} / \mathrm{cm}^{2}\right\}$. It is apparently necessary that the makerial's microstructure be made susceptible to intergranular attack, whether by thermal treatment (scnsitization), or by high levels of ncutron irradiation. The effect of neutron irradiation is to cause displacement of atoms and radiation-cnhanced diffusion. These processes have been found to change the chemical composition at the grain boundaries.

\subsection{Effects of Biological Growth on Pitting and LC}

Microbiologically induced (or influenced) corrosion (MIC) has been observed and studied since the 1800s [1911. Observations of MIC on stainless stecls have been rcported several times since the 1970s [Kobrin, 1976; Tatnall, 1981a; Tatnall, 1981b; Pope et al., 1982; Puckorius, 1983; Gorelov and Talybly, 1983; Pope et al., 1984; Das and Mishra, 1986; Silva et ai., 1986; Kobrin 1986; Thorpe, 1986 and 1987; Pope, 1984; and Hayner et al., 1984] [192-205]. The possibility of the nccurrence of $\mathrm{MIC}$ in deep geological repositories for high-level nuclear wastc has been discussed by West and McKinley [206].

It is clear from the literature that a variety of microbes are capable of inducing corrosion in stainless steels under appropriate conditions. Microbial crevice, pitting, and "gouging" types of corrosion have been scen, as well as SCC.

Sometimes small pits are found to lead to large subsurface cavities in the metal. MIC has been found on Types 304, 304L, E308, 316, and 316L stainless steels, esprecially on welds. Also, Kobrin blamed MIC for some corrosion failures un nickel and Alloy B (Hastelloy) [192]. Pope [207l, in reviewing the work up to 1984, stated: "No cases 
could be made for MIC of these materials (higher nickel-chromium alloys and titaniuml from the available literature. All are resistant to the types of MIC familiar to the scientific and engineering communities at the present time."

Most observed cases of MIC on stainless stecls have occurred in warm water containing an abundance of organic malerial, sulfur comarunds, or both. Examples are often reported from the paper industry, the oil and chemical industrics, and from sewage systems. Cooling systems using river water or seawater have also experienced MIC problems, as have hydrotesting operations using well water.

In cases in which MIC has been observed on stainless sted in relatively pure water, the most common culprits have treen the bacteria Callionella and Sphactutilis. These acrobic bacteria are able to oxidize ferrous to ferric ions or manganous to manganic ions. They co-accumulate chloride ions from the water to achieve charge neutralization. and the resulting solutions are corrosive to stainless steel, particularly to the deita-ferrite phase in the weld metal.

In assessing the liketithood of the occurrence of MIC in a high-level nuclear-waste reposstory in tuff, it must be noted that the conditions there are expected to be unfavorable for the survival of bacteria. These conditions include high temperature; dryness; lack of light; scarcity of electron donor materials such as organics, molecular hydrogen, ammonia, nitrate, or ferrous iron in the natural tuif environment; and the simultancous presence of oxygen and high gamma-ray dose rates near the waste containers.

Temperatures near the containers may range as high as $250^{\circ} \mathrm{C}$, although some may be below the boiling point of water. Most bacteria cannot sur:ive heating above the boiling point, although same have been found to survive al above $2500^{\circ} \mathrm{C}$ ("black smoker" bacteria living in hot sulfurous waler vents on the midocean ridges) [208]. Dryness is not favorable for the growth of bacteria, although some can survive it for long periods. Lack of light precludes the growth of photosyn:thetic species. Without light there must be a themical energy source, including an electron donor. While the tuff environment lacks a significant source, the metal in the packages could serve as one.

The simultaneous presence of oxygen and high gamma-ray dose rates is very deleterious to bacteria. Oxygen is cxpected io be present at near the concentration in the atmosphere. Dose rates at the package surfaces will range up to $10^{4}$ $\mathrm{rad} / \mathrm{hr}$. In comparison, the commercial radiation "sterilization" of medical devices and pharmaceuticals is performed with $2.5 \times 10^{6} \mathrm{rad}$. Hall has found that the sterilization of food for long-term storage requires doses up to $6 \times 10^{6}$ rad [209]. Christensen has found that even the most resistant known bacterial spores (such as those of Micrococcus radiodurans) can be sterilized with doses of no more than a factor of 2 times this [210]. It must be noted that high dose rates will be present only near the surfaces of the packages, and that they will eventually decay. This decay means that the packages wijl be objects of concern for corrosion. The predominant gamma emitter is ${ }^{137} \mathrm{Cs}$, which has a 30 -yr half-life.

in summary, though biological corrosion cannot be totally ruled out, it appears to be very unlikely that a species of bacteria will be found that possesses all the qualities necessary to survive and grow in this environment and also have the capability of corroding stainless stecls [197, 211]. No reports of $\mathrm{MIC}$ on Alloy 825 have bcen found for any environment.

\section{Results and Conclusions}

From the survey of degradation mudes on uniform corrosion, pitting, crevice corrosion, and SCC in austenitic steels, it is obvious that Alloy 825 is the best austenitic candidate among the three being evaluated. From this survey, it is clear that other materiais such as Alloyn C-276 and 625 have superior resistance to localized corrosion. However, they are also signife intly more expersure than the best candidate material, Alloy
825. Materials such as Alloys $C-276$ and $h 25$ are being considered by the Alternate Mattrials Task Group.

The results of the survey can be summirized as follow's:

1. All three austenitic candidates (Types 30 and 316l. stainless stecls and Allov 825) de.monstrated pitteng and crevice corrosion in chlaridecontainnge snvironments. 
2. Alloy 825 has greater resistance to pitting and crevice corrosion than either Types $304 \mathrm{~L}$ or 316L stainless steds.

3. In acidic chloride media, SCC was always observed in Types 304L and 316L.

4. SCC was not reported in the literature for Alloy 825. This does not mean that SCC will not nccur in Alloy 825 under other circumstances.

5. Heat treatment at $600^{\circ} \mathrm{C}$ leads to sensitizatinn of Type 304. This heat treatment does not lead to sensitization of low-carbon alloys such as Types $304 \mathrm{~L}$ and $316 \mathrm{~L}$. Shot peening followed by heat treatment at $6(1))^{\circ} \mathrm{C}$ does increase SCC in Types 304L and 316L. However, the mode of failure is transgranular, not the intergranular mode that would be expected if the samples were sensitized. No data have been found to indicate sensitization in Alloy 825.

6. Gamma irradiation enhances SCC of Types 304 and 316L under some conditions. However, Alloy 825 shows no change in its resistance to SCC in the presence of gamma irradiation.

7. Though microbiologically induced (or influenced) corrosion, and possible SCC, have been observed for 300 -serics stainless steels, the nickelbascd alloys such as Alloy $825 \mathrm{scem}$ to bxe immunc to such problems

8. On the basis of the data from the literature on susceptibility to SCC, the candidates are ranked as follow:s: A.lloy 825 (best) $>$ Type $316 \mathrm{~L}>$ Type $304 \mathrm{~L}$ (worst).

\section{Acknowledgments}

This work was performed under the auspices of the U.S. Department of Energy by Lawrence Livermore National Laboratory under contract No. W-7405-Eng-48, and was supported by the Yucca Mountain Project. The authors thank lay C. Cherniak for his editorial assistance. 


\section{References}

1. "Disposal of High-Level Radioactive Wastes in Ceologic Repositories," Technical Criteria, 10 CFR Part 60, Nuclear Regulatory Agency, Federal Register, Rules and Regulations, Vol. 48, No. 120, Tuesday, June 21, 1983, pp. 28194-28229. HQ2.870302.3019

2. "Environmental Standards for the Management and Disposal of Spent Nuclear Fucl, High-Level and Transuranic Radioactive Wastes," 40 CFR Part 191, Environmental Protection Agency, Federal Register, Rules and Regulations, Vol. 50, No. 192, Thursday, September 19, 1985, pp. 38066-38089. HQ2.870301.5394

3. M. G. Fontana, N. D. Greene, Corrosion Engineering, 2nd ed., McGraw-Hill Book Co., New York, 1978. NNA.891018.0176

4. H. H. Uhlig, Comosion and Corrosion Control: An Introduction to Corrosion Science and Engineering, 2nd ed., John Wiley and Sons, New York, 1971. NNA.891018.0177

5. T. Okada, "Halide Nuclei Theory of Pit Initiation in Passive Metals," lournal of the Electrochemical Socicty, Vol. 131, No. 2, 1984, pp. 241-247. NNA.891005.0087

6. T. Okada, "A Theory of Perturbation-Initiated Pitting," Proceedings of an International Symposium Honoring Professor Marcel Pourbaix on His Eightieth Birthday: Equilibrium Diagrams and Localized Corrosion, Vol. 84-9, Robert P. Frankenthal, Jerome Kruger, Eds., The Electrochemical Society, Pennington, New Jersey, 1984, pp. 402-431. NNA 891005.0088

7. H. W. Pickering, R. P. Frankenthal, "On the Mechanism of Localjzed Corrosion of Iron and Stainless Steel: I. Electrochemical Studies," Journal of the Electrochen ical Society, Vol. 119, No. 10, October 1972, pp. 1297-1304. NNA.891005.0089

8. T. Shibata, T. Takeyama, "Stochastic Theory of Pitting Corrosion," Corrosion, Vol. 33, No. 7, July 1977, pp. 243-251. NNA.891005.0090

9. H. J. EngelI, N. D. Stolica, "Die Kinetik der Entstehung und des Wachstums von Luchfraßstellen auf passiven Eisenclektroden," Zeitschrift für Physikalische Chemie N. F., Vol. 20, 1959, pp. 113-120. NNA.891005.0091

10. M. Janik-Czachor, "An Assessment of the Processes Leading to Pit Nucleation on Iron," Reviews and News, Journal of the Electrochemical Saciely, Vol. 128, No. 12, December 1981, Pp. 513C-519C. NNA.891005.0092

11. G. Matamala R. [sic], "Correlation Model of the AISI 316 Stainless Steel Pitting Potential with Collulose Bleach Process Variables," Corrosion, Vol. 43, No. 2, February 1987, pp. 97-100. NNA.890831.0063

12. C. Y. Chao, L. F. Lin, D. D. MeDonald, "A Point Defect Model for Anodic Passive Films, If. Chemical Breakdown and Pit Initiation," Journal of the Electrochemical Society, Vol. 128, Vol.6, June 1981, pp. 1194-1198. NNA.891005.0093

13. P. E. Manning, D. f. Duquette, W. F. Savage, "The Role of Sulfide Inclusion Morphology in Pit Initiation of Several Type 300 Series Stainless Steels," Corrosion, Vol. 36, No. 6, June 1980, pp. 313-319. NNA.891005.0094

14. L. Hagn, "Lifetime Prediction for Parts in Corrosion Environments," in Corrosion in Power Gencrafing Equipment, Plenum Press, 1983. NNA.891005.0095

15. O. Buck, R. Ranjan, "Evaluation of a Crack-Tip-Opening Displacement Model Under StressCorrosion Conditions," in Modeling Environmental Effects on Crack Growth Processes, R. H. Jones, W. W. Gerberich, Eds., The Mctallurgical Society, 1986, p. 209. NNA.891005.0096

16. R. H. Jones, "Stress Corrosion Cracking," Metals Handbook, 9th ed., Vol. 13, L. J. Korb and D. L. Olson, Co-Chairmen, ASM International, Metals Park, Ohio, Suplember 1987, pp. 145-163. NNA.891005.0097

17. M. Pourbaix, Atlas of Electrochemical Equilibria in Aquenus Solutions, Pergamon Ptess, New York, New York, :966. NNA.891005.0098

18. D. Cubicciotti, L. Ljungberg, "The Pourbaix Diagram of Chromium With Iron and the Stress Corrosion Cracking of Stainless Steel," Journal of the Electrochemical Society, Vol. 1.32, No.4, April 1985, pp. 987-988. NNA.891(X05.0099 
19. 1987 Annual Book of ASTM Standards, Section 3, Metals Test Methods and Analytical Procedures, Volume 3.02, Wear and Erosion; Metal Corrosion, pp. 209-217, ASTM Standard Procedure G36, "Standard Practice for Performing Stress-Corrosion Cracking Tests in a Boiling Magnesium Chloride Solution," American Society for Testing and Materials, Philadelphia, Pennsylvania, 1987. NNA.891005.0100

20. M. Da Cunha Belo, J. Bergner, B. Rondot, "Relationships Between the Critical Potential for Stress Corrosion Cracking of Stainless Steels and the Chemical Composition of the Films Formed in Boiling $\mathrm{MgCl}_{2}$ Solutions," Corrosion Science, Vol. 21, No. 4, 1981, pp. 273-277. NNA.891005.0101

21. G. Cragnolino, "The Significance of a Critical Potential in the Intergranular Stress Corrosion Cracking of Stainless Steel Piping in BWR Environments," Predictive Capabilities in Enzironmentally Assisfed Cracking, Miami Beach, Florida, USA, November 17-22, 1985, American Society of Mechanical Engineers, New York, New York, 1985, pp. 293-318.

22. F. Mancia, A. Tamba, "Electrochemical Prevention and Control of Localized Corrosion and SCC of AISI 304 Stainless Steels in NaCl Solutions," Electrochemical Methods in Corrosion Research, Toulouse, France, fuly 9-12, 1985, Materials Science Forum, Vol. 8, 1986, pp. 189-199.

23. F. P. Ford, "Current Understanding of the Mechanisms of Stress Corrosion and Corrosion Fatigue," Symposium on Environment-Sensitive Fracture: Evaluation and Comparisan of Test Methods, Caithersbury, Maryland, April 26-28, 1982, ASTM Special Technical Publication 821, ASTM Publication Code Number (PCN) 04-82 ${ }^{\prime}$ J-27, S. W. Dean, E. N. Pugh, G. M. Ugiansky, Eds., American Society for Testing and Materials, Philadelphia, Pennsylvania, 1982, pp. 32-51. NNA.891005.0102

24. R. L. Fullman, "Modeling of Composition Effects on the SCC of Stainless Steels," Paper No.6, Proceedings: Seminar on Countermeasures for Pipe Cracking in BWRs, Palo Alto, Colifornia, Vol. 1, May 1980, 8 pages. NNA.891005.0103

25. G. P. Cherepanov, "On the Theory of Crack Growth Due to Hydrogen Embrittlement," Corroston, Vol. 29, No. 8, A ugust 1973, pp. 305-309. NNA.891005.0104

26. J. F. Newman, "The Stress Corrosion of Steel in Sodium Hydroxide Solution: A Film Rupture Model," Corrosion Science, Vol. 21, No. 7, 1981, pp. 487-503. NNA.891005.0105

27. R. H. Jones, M. J. Danielson, C. A. Oster, "Modeling Environmental Effects on Crack Growth," Symposium Proceedings, Metallurgical Sociaty, Warrendale, Pennsyluania, 1986, pp. 41-53. NNA.891005.0106

28. J. Newman, Electrochemical Systems, Prentice Hail, Englewood Cliffs, New Jersey, 1973.

29. T. Nakayama, M. Takano, "Application of Slip Dissolution-Repassivation Model for Stress Corrosion Cracking of AlSI 304 Stainless Steel in a Boiling $42 \% \mathrm{MgCl}_{2}$ Solution," Carrosion, Vot. 42 , No. 1, January 1986, pp. 10-14. NNA.891005.0194

30. P. L. Andresen, "Modeling of Water and Material Chemistry Effects on Crack Tip Chemistry and Resulting Crack Growth Kinetics," 3rd International Conference, Degradation of Materials in Nuclear Power Industry, Traverse Cily, Michigan, August 31-September 4, 1987. NNA .891005.0107

31. 1. Maier, J. R. Galvele, "Straining Metal Electrode Technique as a SCC Test, Type 304 Stainless Steel in $\mathrm{NaCl}+\mathrm{H}_{2} \mathrm{SO}_{4}$ Solutions," Corrosion, Vol. 36, No. 2, February 1980, pp, 60-66. NNA.891005.0108

32. P. 1. Marshall, G. T. Burstein, "Repassivation of Stainless Steels," Internalional Congress on Metallic Corrosion, Toronto, June 3-7. 1984, Vol. 2, National Research Council of Canada, pp. 121-128. NNA.891005.0109

33. T. Hodgkiess, S. Rigas, "A Comparison of the Corrosion Resistance of Some Higher-Alloy Stainless Steels in Seawater at 20-100 ${ }^{\circ}$," Desalination, Vol. 44, 1983, pp. 283-294. NNA.891018.0178

34. R. C. Scarberry, E. L. Hibner, J. R. Crum, "Assessment of Pitting-Potential Measurements in Severely Corrosive Environments," Paper Number 245, Corrosion '79, Allanta, Georgia, March 12-16, 1979, National Association of Corrosion Engineers, Katy, Texas. NNA.890831.0064

35. R. Fratesi, "Statistical Estimate of the Pitting Potential of AISI 316L Stainless Sleel in $3.5 \% \mathrm{NaCl}$ Measured by Means of Two Electrochemical Methods," Corrosion, Vol.41, No. 2, February 1985, pp. 114-117. NNA.891005.0110

36. R. C. Newman, E. M. Franz, "The Protection Potential for Pitting Corrosion of Stainless Steel," International Congress on Metallic Corrosion, Toronto, Juin 3-7, 1984, National Research Council of Canada, Vol. 4, pp. 373-377. NNA.891005.0111 
37. F. Mancia, A. Tamba, "Slow Strain Rate Stress Corrosion Cracking of AIS1 304 Stainless Steel in $\mathrm{NaCl}$ Solution and its Prevention by Controlled Cathodic Protection," Corrosion, Vol. 42, No. 6, June 1986, pp. 362-367. NNA.891005.0112

38. K. A. Lichti, H. Bijnen, P. G. Mcllhone, "A Comparison of Pitting Corrosion and Stress Corrosion Cracking Characteristics of Some Engineering Alloys," Metals Australasia, June-July 1984, Pp. 4-6. NNA.891005.0113

39. ASM Metals Handbook, 9th ed., Vol. 13, L. J. Korb and D. L. Olson, Co-Chairmen, ASM International, Metals Park, Ohio, September 1987, pp. 555-559. NNA.890921.0078

40. A. I. Asphahani, "Localized Corrosion of High Performance Alloys," Materials Performance, Vol. 19, No. 8, August 1980, pp. 9-21. NNA.890831.0071

41. F. H. Yu, C. M. Chen, F. Zhou, W. X. Hu, J. M. Chen, "CEMS, AES and XPS Study of the Role of Molybdenum in 316 Stainless Steel SCC Resistance in High Temperature and High Pressure Water," Journal of the Chinese Society for Corrosion Protection, Vol. 5, No. 3, September 1985, pp. 176-188.

42. D. Warren, "Chloride-Bearing Cooling Water and the Stress-Corrosion Cracking of Austenitic Stainless Steel," Proceedings of the Fifteenth Industrial Waste Carference, May 3-5, 1960, Engincering Bulletin of Purdue Unjversity, Engineering Extension Series, Series No. 106, pp. 420-438. NNA.891005.0115

43. T. Shimose, A. Takamura, K. Mori, K. Shimogori, "Stress Corrosion Cracking of Austemtic Stainless Stecls in Chloride Solutions," Transactions of the Japan Institute of Melals, Vol. 6, No. 2, 1965, pp. 83-87. NNA.891005.0116

44. 1987 Annual Book of ASTM Standards, Section 3, Metals Test Methods and Analytical Procedures, Volume 3.02, Wear and Erosion; Metal Corrosion, p. 169, ASTM Standard Procedure G30, [CCN: 01-030287-27, American Society for Testing and Materials, Philadelphia, Pennsylvania, 1987. NNA.891005.0127

45. 1987 Annual Book of ASTM Standards, Section 3, Metals Test Methods and Analytical Procedures, Volume 3.02, Wear and Erosion; Metal Corrosion, p. 236, ASTM Standard Procedure C39, PCA: 01-030287-27, American Society for Testing and Materials, Philadelphia, Pennsylyania, 1987. NNA.891005.0117

46. F. Mancia, A. Tamba, "Slow Strain Rate Stress Corrosion Cracking of AISI 304 Stainless Steel in $\mathrm{NaCl}$ Solution and Its Prevention by Controlled Cothodic Protection," Corrosion, Vol. 42, No. 6, Jurs 1986, pp. 362-367. NN 1.891005 .0112

47. T. Furuya, T. Fukuzuka, K. Fujiwara, H. Tomari, "Camma-Ray Irradiation Effects on Stress Corrosion Cracking of Alloys tor a High Level Liquid Waste Package," R-D Kobe Sielosho Gijutsu Hokoku, Vol. 33, No. 1. January 1985, Pp. 43-46. NNA.890831,0067

48. M. J. Povich, D. E. Broecker, "The Stress Corrosion Cracking of Austenitic Stainless Steel Alloys in High Temperature Air Saturated Water," Materials Performance, October 1979, pp. 41-48. NNA.891005.011B

49. W. E. Wood, W. W. Gerberich, "Mechanical Nature of Stress-Corrosion Cracking in Al-Zn-Mg Aloys. 2. Electrochemical-Mechanical Model," Melallurgical Transactions, Vol. 5 . No. 6, June 1974, p. 1285. NNA.891005.0119

50. H. D. Solomon, "Transgranular. Granulated and Intergranular Stress Corrosion Cracking in A1SI 304 Stainless Steel," Corrosion, Vol. 40, No. 9, September 1984, pp. 493-506. NNA.891005.0120

51. T. Shibata, K. Furusaki, J. Nakata, "Probability Distribution of Crack Initiation and Propagation Times for Stress Corrosion Cracking of Type 304 Stainless Steel," Boshoku Gijutsu, Vol. 33, No. 4, 1984, pp. 223-231.

52. T. Nakayama, M. Takano, "Stress Corrosion Bchavior of AlSI 304 Stainless Sted in a Boiling $42 \%$ $\mathrm{MgCl} 2$ Solution Under a Cyclic Slow Strain Rate Technique," Corrosion, Vol 42, No. 10, October 1985, pp. 592-597. NNA.891005.0121

53. P. Muraleedharan, H. S. Khatak, ]. B. Gnanamoorthy, P. Rodrigucz, "Elfect of Cold Work on Stress Corrosion Cracking Behavior of Types 304 and 316 Stainless Steels," Metallurgical Transactions, [Section] A, Physical Metallurgy and Maierials Science, Vol. 16. A. Mo. 2, February 1985, Pp. 285-289.

54. D. Itzhak, D. Eljezer, "The Influence of Nal Additions on the Stress Corrosion Cracking of Austenitic Stainless Steel in $\mathrm{MgCl}_{2}$ Solution," Materials Engineering Conference, Haifa, Israel, Decenber 20-22, 1981, Freund Publishing House, P.O. Box 35010. Tel Aviv, Isracl, 1981, pp. 252-256. 
55. W. Y. Chu, J. Yao, C. M. Hsiao, "Stress Corrosion Cracking of Stainless Stecl Under Compressive Stress," Corrosion, Vol. 40, No.6, June 1984, pp. 302-306. NNA.891005.0214

56. H. Uchida, K. Yamamoto, K. Kolerazawa, I. Yamada, H. Kawabe, "Effects of Cold Working and Heat Treatment on Stress Corrosion Cracking Susceptibility of SUS 304 Stainless Steel," lournal of the Society of Materials Science, Japan, Vol. 3U, No. 337, October 1981, pp. 988-994.

57. I. A. Maicr, E. L. Perez, J. R. Galvele, "Straining Metal Electrode as a SCC Test. Type 304 Stainless Steel in $\mathrm{MgCl}_{2}, \mathrm{CaCl}_{2}$, and $\mathrm{LiCl}$ Solutions," Corrosion Science, Vol. 22, No. 6, 1982, pp. 537-550. NNA.891101.0023

58. K. Teramoto, M. Tokano, "Crack Growth Rate in Stress Corrosion Cracking of Type 304 Stainless Steel in Boiling $42 \% \mathrm{MgCl}_{2}$ in the CERT Method," Journal of the lapan Institute of Metals, Sendai. Vol. 43, No. 8, August 1979, pp. 744-752.

59. M. Takano, K. Teramoto, T. Nakayama, H. Yamaguchi, "Extremely Slow Strain Rate Stres\$Corrosion Testing Machine and Some Experimental Results," Tetsu-to-Hagane, Vol. 65, No. 2. February 1979, pp. 212-218.

60. H. Kwon, C. H. Kim, "The Effect of Temperature on the Stress Corrosion Cracking of Austenitic Stainless Stcel," Journal of the Korean Institute of Metals, Vol. 17, No. 6, 1979, pp. 484-490.

61. W. A. Baeslack, IJI, W. F. Sayage, D. J. Duquette, "Effect of Strain Rate on Stress Corrosion Cracking in Duplex Type 304 Stainless Steel Weld Metal," Metallurgical Transactions A-Physical Metallurgy and Materials Science, Vol. 10A, No. 10, October 1979, pp. 1429-1435. NNA.891005.0122

62. A. J. A. Mom, R. T. Dencher, C. J. v. d. Wekken, W. A. Schultze, "Some Aspects of the Stress Corrosion Testing of Austenitic, Martensitic, Ferritic-Austenitic and Ferritic Types of Stainless Steed by Means of the Slow Strain-Rate Method," Conference on the Stress Corrosion Cracking Slow Strain Rate Technique, Toronto, Canada, May 2-4, 1977, American Society for Testing and Materials, Philadelphia, Pennsylvania, pp. 305-319.

63. W. J. Daniels, "Comparative Findings Using the Slow Strain-Rate, Constant Flow Stress and U-Bend Stress Corrosion Cracking Techniques," Conference on the Stress Corrosion Cracking Slow Strain Rate Technique, Toronto, Canada, May 2-4, 1977. American Society for Testing and Malerials, Philadelphia, Pennsylvania, 1979, pp. 347-361.

64. M. J. Robinson, J. C. Scully, "Stress Corrosion Crack Propagation in Austenitic C vinless Steels," Conference on Stress Corrosion Cracking and Hydrogen Embrittlement of Iron Base Alloys, Unieux-Firminy. France, Iune 12-16, 1973, National Association of Corrosion Engineers, Katy, Texas, 1977, pp. 10951103.

65. T. Shibata, T. Takeyama, "Analysis of Stress Corrosion Cracking Failure Times of Type 316 Stainles: Steel by the Weibull Distribution," Boshoku Gijutsu, Vol. 30, No. 1, January 1981, pp, 47-53.

66. K. J. Bundy, V. H. Desai, "Studies of Stress-Corrosion Cracking Behavior of Surgical Implant Materials Using a Frachure Mechanics Approach," Conference on Corrosion and Degradation of Implan Materials, Second Symposium, Louisville, Kentucky, May 9-10, 1983, Amarican Society for Testing and Materials, Philadelphia, Pennsylvania, 1979, pp. 73-90.

67. V. Desai, "Stress Corrosion Cracking Studies of Surgical Implant Alloys," Johns Hopkins University, Disseriation Abstracts International, Vol. 45, No. 11, May 1985.

68. M. C. Belo, J. Bernger, B. Rondot, "Relationships Between the Critical Potential for Stress Corrosion Cracking of Stainless Steels and the Chemical Composition of the Films Formed in Boiling $\mathrm{MgCl}_{2}$ Solutions," Corrosion Science, Vol. 21, No. 4, 1981, pp. 273-277. NNA.891005.0123

69. T. Misawa, "The Use of Recrystallization to Study the Plastic Zone Assaciated with Stress Corrosion Cracking in Type 304 Stainless Steel," Corrosion, Yol. 37, No. 7, July 1981, pp. 427-428. NNA.891005.0124

70. I. A. Ward, H. Masuda, K. R. L. Thompson, L. H. Keys, "The Effects of Environmental Factors on the Mechanical Behavior of Fe-Ni-Cr Alloys and Their Weldments," Conference on Metals and Energy. Aucklar 1, New Zealand, May 19-23, 1980, Australasian Institute of Metals, 191 Royal Parade, Parkville 3052, Victoria, Australia, 1980, pp. 126-129.

71. K. Tanno, Y. Yuasa, H. Yashiro, "Stress Corrosion Cracking of Sensitized AIS1 304 Stainless Steel in Oxygenated $\mathrm{Na}_{2} \mathrm{SO}_{4}$ Solution at High Temperature," Corrosion, Vol. 43, No.4, April 1987, pp. 248-250. NNA.891005.0329 
72. T. Shibata, S. Fujmoto, A. Asada, J. Nakata, "Effect of $\mathrm{CaCl}_{2}$ Concentration on the Probability Distribution of Stress Corrosion Cracking Failure Time of Type 304 Stainless Steel," Journal of the Society of Materials Science, Japan, Vol. 36, No. 400, January 1987, pp. 65-71.

73. T. A. Mozhi, W, A. T. Clark, B. E. Wilde, "The Effect of Nitrogen and Carbon on the Stress Corrosion Cracking Performance of Sensitized AISI 304 Stainless Steel in Chloride and Sulfate Solutions at $250^{\circ} \mathrm{C}^{\prime \prime}$ Corrosion Science, Vol. 27, No. 3, March 1987, pp. 257-273. NNA.891101.0022

74. K. Fujiwara, H. Tomari, K. Shimogori, T. Fukuzuka, "Effects of $\mathrm{pH}$ and Applied Potential on the IGSCC Susceptibility of Sensitized 304 Stainless Steel in Dilute $\mathrm{Na}_{2} \mathrm{SO}_{4}$ Solution at High Temperature," Boshoku Gijutsu, Vol. 30, No. 5, May 1981, pp. 270-275.

75. J. K. Lee, "Stress Corrosion Cracking and Pitting of Sensitized Type 204 Stainless Steel in Chloride Solutions Containing Stulfur Species at Temperatures from $50-200^{\circ} \mathrm{C}_{r}^{\prime \prime}$ Ohio State University, Dissertation Abstracts International, Vol. 47, No 3, September 1986.

76. T. Oki, M. Okido, H. Kanematsu, "Fractography of Sensitized 304 Stainless Steel in Neutral Aqucous Solution by Means of Potentiostatic SSRT Method," Boshoku Gijutsu, Vol. 34, No. 10, 1985, pp. 546551.

77. J. Congleton, R. N. Parkins, T. Shoji, "SCC of an Austenitic Stainless Steel in High Temperature Aqueous Environments," Reports of the Research Institute for Strength and Fracture of Materials, Tohoku University, Vol. 17, No. 1-2, March 1984, pp. 13-28.

78. S. H. Shim, "The Effect of Fluid Flow on the Stress Corrosion Cracking of Sensitized Type 304 Stainless Steel in $0.01 \mathrm{M} \mathrm{Na}_{2} \mathrm{SO}_{4}$ Solution at $250^{\circ} \mathrm{C}$," Ohio State University, Dissertation Abstracts International, Vol. 46, No. 12, June 1986.

79. F. Mancia, A. Tamba, "Slow Strain Rate Stress Corrosion Cracking of AISI 304 Stainless Steel in $\mathrm{NaCl}$ Solution and Its Prevention by Controlled Cathodic Protection," Corrosion, Vol. 42, No.6. June 1985, pp. 362-367. NNA.891005.0112

80. J. Congleton, H. C. Shih, T. Shoji, R. N. Parkins, "The Stress Corrosion Cracking of Type 316 Stainless Steel in Oxygenated and Chlorinated High Temperature Water," Corrosion Science, Vol. 25, No. 8-9, 1985, pp. 769-788. NNA.891005.0125

81. A. Tamba, F. Mancia, "Prevention of SCC of AISl 304 Stainless Steel in NaCl Solution by 'Cathanodic' Protection," Stainless Steel '84, Chalmers University of Technology. Goteborg, Swetien, September 3-4, 1984, The Institute of Metals, 1 Carlton House Terrace, I_ondon SJW1Y 5DB, UK, 1985. Pp. 194-197.

82. D. E. Davies, J. P. Dennison, A. A. Odeh, "The Assessment of Stress Corrosion Damage in Austenitic Stainless Steel by Measurements of Craciss Formed During Constant Strain Rate and Constant Load Tests in $1 \mathrm{M} \mathrm{HCl,"} \mathrm{Corrosion} \mathrm{Science,} \mathrm{Voi.} \mathrm{24,} \mathrm{No.} \mathrm{11-12,} \mathrm{1984,} \mathrm{pp.} \mathrm{953-964.} \mathrm{NNA.891101.0020}$

83. A. Friganani, G. Trabanelli, F. Zicchi, "The Use of Slow Strain Rate Technique for Studying Corrosion Cracking Inhibition," Corrosion Science, Vol. 24, No. 11-12, 1984, pp. 917-927. NNA.891101.0021

84. I. A. Maier, V. Mandredi, J. R. Galvele, "The Stress Corrosion Cracking of an Austenitic Stainless Steel in $\mathrm{HCl}+\mathrm{NaCl}$ Solutions at Room Temperature," Corrosion Science, Vol. 25, No. 1, 1985, pp. 15-34. NNA.891005.0126

85. A. Poznansky, D. J. Duquette, "The Effects of Sulfate and Chloride on the Stress Corrosion Cracking of Type 304 Stainless Steel at $290^{\circ} \mathrm{C}$," Materials Engineering Conference, Haifa, Israel, Decomber 20-22, 1981, Freund Publishing House, P.O. Box 35010, Tel Aviv, Israel, 1981, p. 277

86. A. Poznansky, D. J. Duquette, "The Effect of Sensitization Heat Treatment on the Stress Corrosion Cracking of AISI 304 Stainless Steel," Corrosion, Vol. 40, No. 7, July 1984, pp. 375-381. NNA.891005.0127

87. R. J. L. Meyburg, J. M. Krougman, F. P. ljsseling, "Constant Strain-Rate Testing of A1SI Type 304 Stainless Steel in $0.5 \mathrm{M} \mathrm{H}_{2} \mathrm{SO}_{4}+0.1 \mathrm{M} \mathrm{NaCl}$ Solution at Room Temperature with Controlled Potential," Corrosion Science, Vol. 23, No. 9, 1983, pp. 943-957. NNA.891i01.0019

88. T. Kawakubo, M. Hishida, "Crack Initiation and Growth Analysis by Direct Optical Observation During SSRT in High-Temperature Water," Corrosion, Vol. 40, No. 3, March 1984, pp. 120-126. NNA.891005.0128 
89. W. E. Ruther, W. K. Soppet, G. Ayrault, T. F. Kassner, "Effect of Sulfuric Acid, Oxygen and Hydrogen in High-Temperature Water on Str,s 5 Corrosion Cracking of Sensitized " ype 304 Stainless Steel," Corrosion '83, Anaheim. California, April 18-22, 1983, pamphlet, National Association of Corrosion Engineers, Katy, Texas, 1983.

90. J. Congleton, R. N. Parkins, T. Shoji, "SCC of an Austenitic Stainless Steel in High-Temperature Aqueous Environrients," Corrosion '83, Anakeim, California, April 18-22, 1983, pamphlet, National Association of Corrosion Engineers, Katy, Texas, 1983.

91. A. Poznansky, D. 1. Duquette, "Stress Corrosion Cracking of Anncaled and Sensitized Type 304 Stainless Steel in Deaerated Chloride/Sulfate Solutions at $290^{\circ} \mathrm{C}, "$ Corrosion, Vol. 39, No. 11, November 1983, pp. 425-431. NNA.893005.0129

92. A. Poznansky, "Stress Cortosion Cracking of Type 304 Stainless Steel in Chloride/Sulfate Solutioris," Rensselaer Polytechnic Institute, Dissertation Abstracts International, Vol. 42, No. 12, June 1982.

93. M. Osawa, M. Hascgawa, "Stress Corrosion Cracking of Hydrogen-Containing Austenitic Stainless Stcel in $\mathrm{H}_{2} \mathrm{SO}_{4}-\mathrm{NaCl}$ Solution," Transactions of the Iron and Stedl Institute of lapan, Vol. 21, No. 7 , July 1981, PP. 464-468.

94. D. Eliezer, P. Pinkus, D. Itzhak, "Stress Corrosion of Type 304 Steel in $\mathrm{H}_{2} \mathrm{SO}_{4}$ Alkali Halide Environments," Conference on Environmental Degradation of Engineering Materials in Aggressive Environments, Virginia Polytechnic Institufe and State University, Blacksburg. Virginia, September 21-23, 1981, pp. 193-199.

95. S. Ahmad, M. L. Mehta, S. K. Saraf, I. P. Saraswat, "Stress Corrosion Cracking of Sensitized Stainless Steel in Sulfurous Acid," Corrosion, Vol. 37, No.7, July 1981, pp. 412-415. NNA.891005.0130

96. G. Cragnolino, L. F. Lin, Z. Szklarska-Smialowska, "Stress Corrosion Cracking of Sensitized Type 304 Stainless Steel in Sulfate and Chioride Solutions at 250 and $100^{\circ} \mathrm{C}$," Corrosion, Vol. 37, No. 6, June 1981, pp. 312-320. NNA.891005.0131

97. M. Yajima, M. Arii, "Chloride Stress Corrosion Cracking of AlS1 304 Stainless Steel in Air," Materials Performance, Vol. 19, No. 12, December 1980, pp. 17-19. NNA.891005.0132

98. P. L. Andresen, D. J. Duquette, "The Effect of Chloride Ion Concentration and Applied Potential on the SCC Behavior of Type 304 Stainless Steel in Deaerated High-Temperature Water," Corrosion, Vol. 36, No. 2, February 1980, pp. 85-93. NNA.891005.0133

99. I. Maicr, J. R. Galvele, "Straining Metal Electrode Technique as a SCC Test, Type 304 Stainless Stecl in $\mathrm{NaCl}+\mathrm{H}_{2} \mathrm{SO}_{4}$ Solutions," Corrosion Vol. 36, No. 2, February 1980, pp. 60-66. NNA.891101.0013

100. H.S. Tong, D. J. Swartz, "Stress Corros ion Cracking and Electrochemical Behavici of AISI 304 Stainless Steel in Chloride Containing Sulfate Solutions," Journal of the Electrochemical Society. Vol. 127, No. 1, January 1980, pp. 31-36.

101. P. Norberg, S. Bernhardsson, H. Eriksson, S. Lagerberg, "Corrosion Properties of a Recently Developed Duplex Stainless Steel," 8th European Congress of Corrosion. Nice, France, Notenber 19-21. 1985. Centre Francais de la Corrosion, Societe de Chimie Industrielle, 28 rue Saint-Dominique, F75007, Paris, France, 1986, Vol. 2.

102. T. Shibata, S. Fujimoto, A. Asada, J. Nakata, "Effect of $\mathrm{CaCl}_{2}$ Concentration on the Probability Distribution of Stress Corrosion Cracking Failure Time of Type 304 Stainless Steel," Journal of the Society of Materials Science, Japan, Vol. 36, No. 400, January 1987, pp. 65-71.

103. J. Congleton, R. N. Parkins, J. Shoji, "SCC of Austenitic Stainless Steel in High Temperature Aqueous Environments," Reports of the Research Instilute for Strength and Fracture of Materials. Tohoku University, Vol. 17, No. 1-2, March 1984, pp. 13-28.

104. J. Congleton, H. C. Shih, T. Shoji, R. N. Parkins, "The Stress Corrosion Cracking of Type 316 Stainless Steel in Oxygenated and Chlorinated High Temperature Water," Corrosion Science, Vol. 25, No. 8-9, 1985, pp. 769-788.

105. P. S. Maiya, "Quantitative Description of Strain Rate Effects on Susceptibility to Intergranular Stress Corrosion Cracking," Fraclure '84, Conference on Advances in Fracture Research, New Delhi, India, December 4-10, 1984, Pergamon Press Ltd., Headington Hill Hall, Oxford OX3 OBW, U.K., 1984, Vol. 4, pp. 2335-2343. 
106. J. P. Sheehan, C. R. Morin, K. F. Packer, "Study of Stress Cornosion Cracking Susceptibility of Type 316L Stainless Steel in Vitro," Conference on the Corrosion and Degradation of Implant Materials, Second Symposium, Louistitle, Kentucky, May 9-10, 1983, American Society for Testing and Materials, Philadelphia, Pennsylvania, 1985, pp. 57-72.

107. J. Congleton, R. N. Parkins, T. Shoii, "SCC of an Austenitic Stainless Steel in High-Temperature Aqueous Environments," Corrosion '83, Anaheim, California, April 18-22, 1983, pamphlet, National Association of Corrosion Engineers, Katy, Texas, 1983.

108. T. Oki, H. Kondou, S. Kuwano, "Metal-Electrochemical Study on Stress Corrosion Cracking of Type 316 Austenitic Stainless Steel in 3\% NaCl Solution by Potentiostatic CERT Method," Journal of the Society of Materials Science, Japan, Vol. 31, No. 345, June 1982, pp. 584-588.

109. J. P. Carter, F. X. McCawley, "Corrosion Tests in Brine and Steam from the Salton Sea KGRA," Journal of Materials for Energy Systems, Vol. 3, No. 4, March 1982, Pp. 30-38.

110. T. Kawakubo, M. Hishida, "J-Integral Analysis of SCC Growth Rate in High Temperature Water," Boshoku Gijutsu. Vol. 31, No. 1, January 1982, pp. 19-26. NNA.891005.008926.

111. G. Buzzanca, E. Caretta, L. Meini, R. Pascali, C. Ronchetti, "A Contribution to the Interpretation of the Strain Rate Effect on Type 304 Stainless Steel Intergranular Stress Corrosion Cracking," Corrosion Science, Vol. 25. No. 8-9, 1985, pp. 805-813. NNA.891101.0018

112. D. A. Hale, "The Effect of BWR Startup Environments on Crack Growth in Structural Alloys," Journal of Enginecring Materials and Technology, Vol. 108, No. 1, January 1986, pp. 44-49.

113. S. M. Bruemmer, R. H. Jones, J. R. Divine, A. B. Johnson, Jr., "Evaluating the Intergranular SCC Resistance of Sensitized Type 304 Stainless Steel in Low-Temperature Water Envitonments," Conference on Environment-Sensitive Fracture: Evaluation and Comparisun of Test Methods. Gaithersburs. Maryland, April 26-28,1982, American Society for Testing and Materials, Philadelphia, Pennsylyania, 1984, pp. 256-270.

114. H. D. Solomon, "Transgranular, Granulated and Intergranular Stress Corrosion Cracking in AlSI 304 SS," Corrosion, Vol. 40, No. 9, September 1984, pp. 493-506. NNA.891005.0134

115. M. Silverman, D. F. Taylor, "The Influencc of Crevice Chemistry on Constant Extension Rate Tensile (CERT) Tests of 304 L Stainless Steel in $288^{\circ} \mathrm{C}$ Water," Corrosion, Vol. 37, No. 1, January 1981, Pp. 58-60. NNA.891005.0135

116. J. Kuniya, I. Masaoka, R. Sasaki, S. Kirihara, "Effects of Surface Finishing on Stress Corrosion Cracking of Austenitic Stainless Steels in High-Temperature Water," lournal of Malerials for Energy Systems, Vol. 1, No. 4, March 1980, pp. 30-41.

117. M. J. Povich, D. E. Broecker, "The Stress Corrosion Cracking of Austenitic Stainless Steel Alloys in High-Temperature Air-Saturated Water," Materials Performance, Vol. 18, No. 10, October 1979, Pp. 41-48. NNA.891005.0118

118. J. Kuniya, S. Hattori, J. Masaoka, R. Sasakj, H. Ito, "Stress Corrosion Cracking Susceptibility of Various Austenitic Stainless Stecl Pipe Welds in High Temperature Oxygenated Water," Boshoku Gijulsu, Vol. 31, No. 4, April 1982, pp. 261-267.

119. E. Kikuchi, N. Ohnaka, A. Minato, "Statistical Evaluation of IGSCC Resistance of Various Austenitic Stainless Steels in High Temperature Water With Impurities," Boshoku Gijutsu, Vol. 33, No. 10, 1984, pp. 566-572.

120. H. Takaku, K. Kuwabara, M. Kusuhashi, "Susceptibility to SCC of High Nitrogen Forged Stainless Steel Pipe." Materials Performance. Vol. 21, No. 5, May 1982, pp. 36-42. NNA.891005.0136

121. M. J. Povich, D. E. Broccker, "The Stress Cotrosion Cracking of Austenitic Stainless Steel Alloys in High-Temperature Air-Saturated Water," Materials Performance, Vol. 18, No. 10, October 1979, pp. $41-48$.

122. T. Kawakubo, M. Hishida, "An Analysis of Cracking Behavior During CERTS," Conference on Predictive Melhods for Assessing Corrosion Damage to BWR Piping Steam Generators, Fuji, Japan, May 28Iune 2, 1978, National Association of $\mathrm{Cr}$ :osion Engineers, Katy, Texas, 1982, pp. 266-270.

123. 1. N. Kass, R. L. Cowan, "Hydrogen Water Chemistry Technology for BWR's," Proceeuings of the Second International Symposium on Environmental Degradation of Materials in Nuclear Power SystemsWater Reactors, Monterey. Californis. Scptember 9-12, 1985, American Nuclear Society, 1986, Pp. 211-218. NNA.891026.0002 
124. H. C. Park, G. Cragnolino, D. D. MacDonald, "Stress Corrosion Cracking of Sensitized Type 304 Stainless Steel in Borate Solutions at Elevated Temperatures," Conference on Environmental Degradation of Materials in Nuslear Power Systems-Water Reactors, Myrtle Beach, South Carolina, August 22-25, 1983, National Association of Corrosion Engineers, Katy, Texas, 1984, pp. 604-622. NNA.891026.0003

125. H. Tsuge, N. Maruyama, S. Nagata, H. Nagano, "Stress Corrosion Cracking of Austenitic Stainless Steels in Borated Water," Conference on Environmental Degradation of Materials in Nuclear Power Systems-Water Renctors, Myrtle Beach, South Carolina, August 22-25, 1983, National Association of Corrosion Engineers, Katy, Texas, 1984, pp. 582-591. NNA.891026.0004

126. R. B. Davis, M. E. Indig, "The Effect of Aqueous Impurities on the Stress Corrosion Cracking of Austenitic Stainless Steel in High-Temperature Water," pamphlet, National Association of Corrosion Engineers, Katy, Texas, 1983.

127. H. Hirano, N. Aoki, T. Kurosawa, "The Elfect of Dissolved Oxygen and $\mathrm{NO}_{3}^{-}$Anions on the Stress Corrosion Cracking of Type 304 Stainless Steel in Water at $290^{\circ} \mathrm{C}_{r}$ "Corrosion, Vol. 39, No. 8, August 1983, pp. 313-322. NNA.891005.0137

128. 5. Shmad, M. L. Mehta, S. K. Saraf, I. P. Suraswat, "Stress Corrosion Cracking of Sensitized 304 Austenitic Stainless Steel in Petroleum Refinery Environment," Corrosion, Vol. 38, No. 6, June 19k2, pp. 347-353. NNA.891005.0138

129. R. C. Newman, K. Sieradzki, H. S. isaacs, Fraclure Mechanisms of Sensilized Stainless Steels in Sulfiur Containing Environments. Brookhaven National Laboratory, Upton, New York, Report No. DE81026052, 1981.

130. R. C. Newman, K. Sieradzki, H. S. Isaacs, "Fracture Mechanisms of Sensitized Stainless Stevls in Sulfur-Containing Environments," Conference on Environmental Degratation of Engintering Materinls in Aggressive Environments, Blacksburg, Virginia, September 21-23.1987, Virginia Polytechnic Institute, Blacksburg, Virginia, 1981, pp. 163-171.

131. J. Congleton, H. C. Shih, T. Shoji, R. N. Parkins, "The Stress Corrosion Cracking of Type 316 Stainless Steel in Oxygenated and Chlorinated High Temperature Water," Corrosion Science, Vol. 25. No. 8-9, 1985, pp. 769-788.

132. B. M. Gordon, "The Effect of Chloride and Oxygen on the Stress Corrosion Cracking of Stainless Stecls: Review of Literature," Materials Performance, Vol. 19, No. 4, April 1980, pp. $29-38$. NNA.891005.0139

133. W. L. Williarns, "Chloride and Caustic Stress Corrosion of Austenitic Stainless Steel in Hot Water and Steam," Corrosion, Vol. 13, No.8, August 1957, p. 539t-545t. NNA.890831.0065

134. H. R. Copson, Physical Metallurgy of Stress Corrosion Fracture, Interscience, 1959, p. 247.

135. J. C. S. Wu, Sensitization, Intergranular Aftack, Stress Corrosion Cracking, and Irradiation Effects on the Carrosion of Iran-Chromium-Nickel Alloys, Westinghouse Electric Corporation, Advanced Reactars Division, Oak Ridge National Laboratory, Oak Ridge, T. 11: ee, ORNL/TM-6311, April 1978. NNA.891026.0008

136. H. Y. Suss, "Untempered Martensite Affects Stress-Corrosion of Type 410 Stainless," Metal Prozrezs, Vol. 82, 1962, p. 89.

137. D. Van Rooyen, "Review of the Stress Corrosion Cracking of Inconel 600," Corrosion, Vol. 31, Vo. 4, September 1975. NNA.891005.0140

138. R. W. Stachle, A Study of the Mechanism of Stress Corrosion Cracking in the Iron-Nickel Chromium Allyy System, Final Report. RF (Research Foundation) Project 1673, The Ohio State University Research Foundation, Columbus, Ohio, Report No. COO-1319-82; U.S. Atomic Energy Commission Contract No. AT(11-1)-1319, February 1970. NNA.891005.0141

139. M. Kowaka et al., "Development of Nuclear Grade Type 316 Stainless Steel for BWR Piping," Sumilomo Melals, Vol. 34, No. 1, lar!dary 1982, Pp. 85-99.

140. A. Duckworth, J. Metcalf, P. J. Morcland, "The Selection and Performance of Materials in Fine Chemicals Plant," Industrial Corrosion, Vol. 2, No. 3, March 1984, pp. 12-15.

14]. A. Kyrolainen, "Initiation of Pitting at Inclusions in Calcium Treated Stainless Stecl," Stainless Sfeel '84, Chalners University of Technology, Goteborg. Sweden, September 3-4, 1984. The Institutc of Metals, 1 Carlton House Terrace, London SW1Y 5DB, U.K., 1985, pP. 173-180. 
142. I. P. Carter, S. D. Cramer, R. K. Conrad, "Corrosion of Stainless Steels in the Geothermal Environments of the Salton Sea Known Geothermal Resource Area," Corrosion '81. Toronto, Canada, April 6-10, 1981, pamphlet, National Association of Corrosion Engineers, Katy, Texas, 1981.

143. T. Fujii, "Pitting Potentials of Stainless Steel in $0.1 \mathrm{M} \mathrm{NaCl}$ Solution at $280^{\circ} \mathrm{C}$," Transactions of National Research Institufe for Metals (Japan), Vol. 21, No. 1, March 1979, pp. 11-12.

144. P. S. Maiya, "Corrosion Studies on Structural Alloys for Flue Gas Desulfurization Systems," Corrosion in Flue Gas Desulfurization Systems, Anaheim, Caltfornia, New Orleans, Louisiana, USA, April 21, 1983; April 5-6, 1984, National Association of Corrosion Engineers, Katy. Texas, 1984, pp. 93-107.

145. R. Oltra, J. C. Colson, A. Desesatret, "The Electrochemical Effect of Chromium, Nickel, and Molybdenum Additions on the Stress Corrosion Cracking of Austenitic Stainless Steels in a Chloride' Solution," Corrosion, Vol. 42, No. 1, January 1986, pp. 44-50. NNA.891005.0142

146. E. C. Bain, R. H. Aborn, J. J. B. Rutherford, "The Nature and Prevention of Intergranular Corrosion in Austenitic Stecls," Transactions of the American Society for Steel Treating, Vol. 21, 1933, p. 481. NNA.891005.0143

147. C. Stawstrom, M. Hillert, "An Improved Depleted-Zone Theory of Intergranular Corrosion of 18-8 Stainless Stcel." Iournal of the Iron and Steel institute, Vol. 207, 1969, p. 77. NNA.891005.0144

148. C.S. Tedmon, Jr., D. A. Vermilyea, J. H. Rosolowski, "Intergranular Corrosion of Austenitic Stainless Steel," lournal of the Electrochemical Society, Vol. 118, 1971, p. 192. NNA.891005.0145

149. R. L. Fullman, "A Thermodynamic Model of the Effects of Composition on the Susceptibility of Austenitic Stainless Stcels to Intergranular Stress Corrosion Cracking," Acta Mefallurgica, Vol. 30 , 1982, pp. 1407-1415. NNA.891005.0146

150. H. Takaku, K. Kuwabara, M. Kusuhashi, “Susceptibility to SCC of High Nitrogen Forged Stainless Stcel Pipe," Matcrials Performance, Vol. 21, No. 5, May 1982, pp. 36-42. NNA.89](005.0147

151. A. P. Majidi, M. A. Streicher, "Four Nondestructive Electrochemical Tests for Detecling Sensitization in Type 304 and 304L Stainless Steels," Nuclear Technolugy, Vol. 75, No. 3, December 1986, Pp. 356-369.

152. R. W. Arcy, F. F. Lyle, Jr., Evaluation of the EPR Techrique and the WC-5 Metal Stmeitization Detector for Determining Susceptibility of Austenitic Stainless Steels to Intergyanular Corrosion, Materials Technolng: Institute of the Chemical Process Industries, Inc., 1570 Fishinger Rd., Columbus, Ohio 43221, 1983.

153. W. L. Clark, Reactor Primary Coolant System Pipe Rupture Study Method for Detection of Sensitization in Stainless Steel, Ceneral Electric Company, Report No. NUREC/CR-0834, August 1979.

154. M. J. Povich, D. E. Broecker, "The Stress Corrosion Cracking of Austenitic Stainless Steel Alloys in High-Temperature Air-Saturated Water," Materials Performance, Vol. 18, No. 10, October 1979, pp. 41-48. NNA.891005.0118

155. M. Kowaka, H. Nagano, K. Yoshikawa, T. Kobayashi, M. Miura, Y. Sawaragi, K. Ohta, S. Nagata, "Development of Alternative Materials for BWR Piping," Procedings on the Conference for Predictiv' Methods of Assessing Corrosion Damage to BWR Piping and PWR Steam Cenerators. Fuil Institute of Education and Training, lapan, May 28-June 2, 1978, published 1982, pp. 193-197. NNA 891005.0148

156. T. Kudo, H. Miyuki, Y. Nakamura, H. Yoshinaga, T. Nakamura, "Corrosion Resistance of As-Rolles Types 304 and 316 Stainless Stcels for Clad Steel Lise." Sumitomo Metals. Vol. 35. No. 1, March 1983. pp. 81-92.

157. J. N. Kass, W. L. Walker, A. J. Giannuzzi, "Stress Corrosion Cracking of Welded Type 304 Stainless Steel Under Cyclic Loading," Corresion '79, AlJanfa, Georgia, March 12-16, 1979. National Association of Corrosion Engineers, Katy, Texas, 1979.

158. R. M. Davison, D. W. Rahoi, G. Gemmel, "Stainless Steels for Heat Exchanger Service," Industrial Heal Exchangers, Piltsburgh, Pennsylvania. USA, Notember 6-8, 1985, American Society for Metals, Metals Park, Ohio, 1985, pp. 371-380.

159. Chikazaki, Mitsuo, "Improvement in the Grain Boundary Corrosion Resistance of Nickel-Based Alloys," Japanese Kokai Tokkyo Koho, JP 54/69517, June 4, 1979.

160. S. M. Bruemmer, "Composition-Based Correlations to Predict Sensitization Resistance of Austenitic Stainless Stcels," Corrosion, Vol. 42, No. 1, January 1986, pp. 27-35. NNA.891015.0149 
161. T. A. Mozhi, H. S. Betrabet, V. Jagannathan, B. E. Wilde, W. A. T. Clark, "Thermodynamic Modeling of Sensitization of AISI 304 Stainless Steels Containing Nitrogen," Scripta Metallurgica, Vol. 20, 1986, pp. 723-728. NNA.891005.0150

162. T. A. Mozhi, W. A. T. Clark, K. Nishimoto, W. B. Johnson, D. D. MacDonald, "The Effect of Nitrogen on the Sensitization of AISI 304 Stainless Stcel," Corrosion, Vol. 41, No. 10, October 1985, pp. 555-559. NNA.891005.0151

163. T. Kekkonen, P. Aaltonen, H. Hanninen, "Metaliurgical Effects on the Corrosion Resistance of a Low Temperature Sensitized Welded AISI Type 304 Stainiess Stecl," Corrosion Science, Vol. 25, No. 89, 1985, pp. 82]-836. NNA.891005.0152

164. G. S. Was, R. M. Kruger, "A Thermodynamic and Kinetic Basis for Understanding Chromium Depletion in Ni-Cr-Fe Alloys," Acta Metallurgica, Vol. 33, No. 5, 1985. pp. 841-854. NNA.891005.0153

165. R. A. Mulford, E. L. Hall, C. L. Briant, "Sensitization of Austenitic Stainless Steels, Il. Commercial Purity Alloys," Corrasion, Vol. 39, No. 4, April 1983, pp. 132-143. NNA.891005.0154

166. C. L. Briant, R. A. Mulford, E. L. Hall, "Sensitization of Austenitic Stainless Steels, I. Controlled Purity Alloys," Corrosion, Vol. 38, No. 9, September 1982, pp. 468-477. NNA.891005.0155

167. M. Kowaka, "Methods for Determining and Predicting Sensitization of Fe-CT-Ni Base Altoys in Japan," Proceedings of the Conference on Predictive Methods for Assessing Corrosion Damage to BWR Piping and PWR Steam Generators, Fuji Institute of Education and Training, Japan, May 28-June 2, 7978 , published 1982, pp. 205-208. NNA.891005.0156

168. Robert L. Fullman, "Predictability of Low Temperature Sensitization in Stainless Steels," Proceedings: Seninar on Countermeasures for Pipe Cracking in BWRs, Palo Alto, California, May 1980, Vol. 2, Paper No. 26, 13 pages. NNA.891005.0157

169. J. J. Eckenrod, C. W. Kovach, Effect of Nitrogen on the Sensitization, Corrosion, and Mechanical Propertics of $78 \mathrm{Cr}-8 \mathrm{Ni}$ Stainless Steets, Amerjcan Society for Testing and Materials, Philadelphia, Pennsylvania, ASTM Report No. STP-679, 1979, pp. 17-41. NNA.891005.0158

170. M. J. Povich, P. Rao, "Low Temperature Sensitization of Welded Type 304 Stainless Steel," Corrosion, Vol. 34, No. 8, August 1978, pp. 269-275. NNA.891005.0159

171. M. J. Povich, "Low Temperature Sensitization of Type 304 Stainless Steel," Corrosion, Vol. 34, No. 2, February 1978, pp. 60-65. NNA.891005.0160

172. C. L. Briant, "Grain Boundary Segregation of Phosphorus in 304L. Stainless Steel," Metallurgical Transactions, [Section] A: Physical Mefallurgy and Materiais Science, Vol. 16A, No. 11, November 1985, pp. 2061-2062.

173. R. H. Jones, "Some Radiation Damage-Stress Corrosion Synergisms in Austenitic Stainless Steels," in Proceedings of the Second International Symposium on Environmental Degradation of Materials in Nuclear Power Systems-Water Reactors, American Nuclear Sociefy, September 1985, p. 173. NNA.891026.0005

174. A. L. Asphahani, "Effect of Acids on the Stress Corrosion Cracking of Stainless Materials in Dilute Chloride Solutions," Materials Petformance. November 1980, pp. 9-14. NNA 890831.0066

175. A. I. Asphahani, H. H. Uhlig, "Stress Corrosion Cracking of 4140 High Strength Steel in Aqueous Solutions," Journal of the Electrochemical Society, Vol. 122, No. 2, 1975, p. 174. NNA.891101.0117

176. H. H. Uhlig, E. W. Cook, Jr., "Mechanism of Inhibiting Stress Corrosion Cracking of 18-8 Stainless Steel in $\mathrm{MgCl}_{2}$ by Acetates and Nitrates," Iournal of the Electrochemical Sociefy, Vol. 116, No. 2, 1969. p. 173. NNA.891005.0161

177. R. S. Glass, G. E. Overturf, R. A. Van Konynenburg, R. D. MeCright, "Gamma Radiation Effects on Corrosion: I. Electrochemical Mechanisms for the Aqueous Corrosion Processes of Austenitic Stainless Steels Relevant to Nuclear Waste Disposal in Tuff," Corrosion Science, Vol. 26, No. 8, 1986, pp. 577-590. NNA.891005.0162

178. R. S. Glass, R. A. Van Konymenburg, C. E. Overturf, "Cortosion Processes of Austenitic Stainless Steels and Copper-Based Materials in Gamma-Irradiated Aqueous Environments," Proceedings of Currosion 86, The International Forum Dezoled Exclusively to the Frotection and Performance of Materials, March 77-21, 1986, Albert Thomas Conventian Cenler, Houston. Texas, Paper No. 258, 11 pages. NNA.891005.0163

179. G. P. Marsh, K. J. Taylor, G. Bryan, S. E. Worthington, "The Influence of Radiation on the Corrosion of Stainless Steel," Corrosion Science, Vol. 26, No. 11, 1986, p. 971. NNA.891005.0164 
180. Y. J. Kim, R. A. Oriani, "Corrosion Properties of the Oxide Film Formed on Grade 12 Titanium in Brine Under Gamma Radiation," Corrosion, Vol. 43, No. 2, February 1987, pp. 85-91. NNA.891005.0165

181. Y. J. Kim, R. A. Oriani, "Brine Radiolysis and its Effect on the Corrosion of Grade 12 Titanium," Corrosion, Vol. 43, No. 2, February 1987, pp. 92-96. NNA.891005.0166

182. W. L. Clarke and A. J. Jacobs, "Effect of Radiation Environment on SCC of Austenitic Materials," Proceedings of the Conference on Entironmental Degradation of Materials in Nuclear Power SystemsWater Reaclors, Myrtle Beach, South Carolita, August 22-25, 1983, National Association of Corrosion Engineers, Katy, Texas, 1984, pp. 451-461. NNA.891005.0167

183. W. E. Ruther, W. K. Soppet, T. F. Kassnet, "Influence of Gamma Radiation on the ECP of Type 304 SS, Ti, and Pt in $289^{\circ} \mathrm{C}$ Water," presented at .Meeting of the Inter national Cooperative Group on Irradiation on Stress Corrosion Cracking, Sponsored by the American Nuclear Society. The Metallurgical Society, and the National Association of Corrosion Engineers, Traverse City, Michigan, September 3-4, 1987. NNA.891005.0168

184. A. J. Bard, L. R. Faulknes, Electrochemical Systems, Fundamentals and Applications. John Wiley and Sons, New York, New York, 1980, pp. 699-702.

185. J. W. T. Spinks, R. J. Woods, An Introduction to Radiation Chemistry, Second ed., John Wiley and Sons, New York, 1976, p. 261.

186. N. Fujita, M. Akiyama, T. Tamura, "Stress Corrosion Cracking of Sensitized Type 304 Stainless Steel in High Temperature Water Under Gamma Ray Irradiation," Corrosion, Vol. 37, No. 6, June 1981, pp. 335-341. NNA.891005.0169

187. K. Ishigure, J. Takagi, Y. Takeuchi, N. Fujiti, M. Muroi, "Effect of Gamma Radiation on Cortosion of Stainless Steel in High-Temperature Water," Proceedings of the Srcond International Symposium on Environmental Degradation of Materials in Nuclear Power Systems-Water Reactors, Monterey, California, September 9-12, 1985, American Nuclear Society, La Grange Park, Illinois, 1986, pp. 181-188. NNA.891018.0179

188. M. Kuribayashi, H. Okabayashi, "Influence of Gamma-Ray Radiation on Stress Corrosion Cracking of Austenitic Stainless Steel," Journal of the japan Imstitule of Metals, Sendai, Vol. 46, No. 2, 1982, pp. 170-175. NNA.891018.0170

189. E. Kikuchi, N. Ohnaka, A. Minato, "Effect of Hydrogen Peroxide on Stress Cortosion Cracking of Type 304 Stainless Steil (Retroactive Coverage)," Boshoku Gijutsu, Vol. 33, 1984, p. 33. NNA.891005.0171

190. L. A. James, Envirommentally-Assisted Cracking Behavior of a Candidate Basalt Repasilory Containtr Matcrial in Groundwater Undergoing Gamma Irradiation, Westinghouse Hanford Company, Richland, Washington, HEDL-SA-3707 FT, April 1987. Also, Nuclear and Waste Management (in press). NNA.891018.0180

191. R. L. Starkey, "Anaerobic Corrosion, Perspectives About Causes," Biologically Induced Corrosion, NACE-8. Proceedings of the Internafional Conference on Biologically Induced Corrosion, Gaithersburg, Maryland, June 10-12, J985, S. C. Dexter, Ed., National Association of Corrosion Engineers, Katy, Texas, 1986, pp. 3-7. NNA.891026.0006

192. C. Kobrin, "Corrosion by Microbiological Organisms in Natural Waters," Malerials Performance. Vol. 15, No. 7, July 1976, pp. 38-43. NNA.891005.0172

393. R. E. Tatnall, "Case Histories: Bacteria induced Corrosion," Materials Performance, Vol. 20, o. 8. August 1981, pp. 4]-48. NNA.891005.0173

194. R. E. Tainall, "Fundamentals of Bacteria Induced Corrosion," Materials Parformance. Vol. 20, No. 9. September 1981, pp. 32-38. NNA.891005.0174

195. D. H. Pope, R. J. Soracco, E. W. Wilde. "Studies on Biologically Induced Corrusion in Heat Exchanger Systems at the Sayannah River Plant, Aiken, SC," Materials Performance. Vol. 21, No. 7. July 1982, pp. 43-50. NNA.891005.0175

196. P. R. Puckorius, "Massive Utility Condenser Failure Caused by Sulfide Producing Bacteria," Matcrials Performance, ' ol. 22, No. 12, December 1983, pp. 19-22. NNA.891005.0176 
197. V. V. Gorelov, A. K. Talybly, "Corrosion Protection of the Equipment in Closed and Reduced-Water Recycling Systems," Pulp and Paper Industry Problems, Vol. 4, Fourth International Symposium on Corrosion in the Pulp and Paper Industry, Stockhalm, Szueden, May 30 to June 2, 1983, published by the Swedish Corrosion Institute, Stockholm, Sweden, 1983, pp. 113-116.

198. D. H. Pope, D. J. Duquette, A. H. Johannes, P. C. Wayner, "Microbiologically Influenced Corrosion of Industrial Alloys," Materials Performance, Vol. 24, No. 4, April 1984, Pp. 14-18. NNA.891005.0177

199. C. R. Das, K. G. Mishra, "Biological Corrosion of Welded Steel due to Marine Algae," Biologically Induced Corrosion, NACE-8, Proceedings of the International Conference on Biologically Ind uced Corrosion. June 10-12, 1985, Gaithersburg, Moryland, S. C. Dexter, Ed, National Association of Corrosion Engineers, Katy, Texas, 1986, pp. 114-117. NNA.891005.0178

200. A. J. N. Silva, J. N. Tanis, J. O. Silva, R. A. Silva, "Alcohol Industry Biofilms and their Effect on Corrosion of 304 Stainless Steel," Biologically Induced Corrosion, NACE-8, Proceedings of the International Conference on Biologically Induced Corrosion, Iune 10-12, 1985, Gaithersburg, MaryJand, S. C. Dexter, Ed., National Association of Corrosion Engineers, Katy, Texas, 1986, pp. 76-82. NNA.891018.0182

201. G. Kobrin, "Rellections on Microbiologically Induced Corrosion of Stainless Stecls," Biologically Induced Corrosion. NACE-8, Proceedings of the International Conference on Biologically Induced Corrosion. June 10-12, 1985, Gaithersburg, Maryland, S. C. Dexter, Ed, National Association of Corrosion Engineers, Katy, Texas, 1986, pp. 33-46. NNA.891018.0183

202. P. H. Thorpe, "Microbiological Corrosion of Slainless Steel in Paper Machines and its Causes," Proceedings of the Fifth International Sympasium on Corrosion in the Pulp and Paper Industry, National Association of Corrosion Engineers, Katy, Texas, pp. 169-173.

203. P. H. Thorpe, "Microbiological Corrosion of Stainless Steel in Paper Machines," Appila, Vol. 40, No. 2, 1987, pp. 108-11].

204. D. H. Pope, D. J. Duquette, A. H. Johannes, P.C. Wayner, "Microbiologically Influenced Corrosion of Industrial Alloys," Materials Performance, Vol. 24, No. 4, April 1984, Pp. 14-18.

205. G. O. Hayner, D. H. Pope, B. E. Crane, "Microbiologically Influenced Corrosion in the Condenser Water Boxes at Crystal River-3," Materials Performance, Vol. 24, No. 4, April 1984. NNA.891026.0007

206. J. M. West, I. G. McKinley, "The Geomicrobiology of Nuclear Waste Disposal," Scientific Basis for Nuclear Waste Management VII, Materials Research Society Symposia Proceedings, Vol. 26, G. L. McVay, Ed., North-Holland, New York, 1984, pp. 487-494. NNA.891018.0184

207. D. H. Pope, "Microbiologically Influenced Corrosion in the Nuclear Power Industry: Case Histories, Methods of Detection, Control, and Prevention," Proceedings of the Third International Symposium on Environmental Degradation of Materials in Nuclear Power Systems-Water Reactors. Traverse City. Michigan, August 30 to September 3, 1987, The Metallurgical Society, 1988 (in press). NNA 891026.0009

208. I. A. Baros5, ]. W. Deming, "Growth of 'Black Smoker' Bacteria at Temperatures of at Least $250^{\circ} \mathrm{C}$," Nature, Vol. 303, June 2, 1983, pp. 423-426. NNA.891018.0185

209. E. J. Hall, Radiation and Life, 2nd ed., Pergamon Press, New York, 1984, p. 203. NNA.891018.0186

210. E. Christensen, "Report from Denmark," Radiosterilization of Medical Products, Pharmaceuticals and Bioproducts, International Atomic Energy Agency, Vienna, Technical Report Series No. 72, 1967, P. 60-74. NNA.891018.0187

211. J. G. Stoecker, "Guide for the Investigation of Microbiologically Induced Corrosion," Matetials Performance, Vol. 24, No. 8, August 1984, pp. 48-55. NNA.891018.0181 
The following number is for Office of Civilian Radioactive Waste Management Records Management purposes only and should not be used when ordering this document:

Accession Number. NNA,891222,0308 